UNIVERSIDADE DE SÃO PAULO

FACULDADE DE FILOSOFIA, LETRAS E CIÊNCIAS HUMANAS DEPARTAMENTO DE GEOGRAFIA

PROGRAMA DE PÓS-GRADUAÇÃO EM GEOGRAFIA HUMANA

NABOR FRANCISCO DA SILVA JUNIOR

\title{
Educação: O negócio do SESI-SP e as necessidades dos estudantes!
}

São Paulo 


\section{NABOR FRANCISCO DA SILVA JUNIOR}

\section{Educação: O negócio do SESI-SP e as necessidades dos estudantes!}

Dissertação apresentada ao Programa de PósGraduação em Geografia Humana do Departamento de Geografia da Faculdade de Filosofia, Letras e Ciências Humanas da Universidade de São Paulo, para obtenção do título de Mestre em Geografia sob a orientação da Prof $^{a}$ Dr $^{a}$ Maria Eliza Miranda.

São Paulo 
Autorizo a reprodução e divulgação total ou parcial deste trabalho, por qualquer meio convencional ou eletrônico, para fins de estudo e pesquisa, desde que citada a fonte.

Catalogação da Publicação

Serviço de Biblioteca e Documentação

Faculdade de Filosofia, Letras e ciências Humanas da Universidade de São Paulo

SILVA JR, Nabor F. S. da. Educação: o negócio do SESI-SP e as necessidades dos estudantes/ Nabor Francisco da Silva Junior; orientadora Prof ${ }^{a}$ Dr $^{a}$ Maria Eliza Miranda. - São Paulo, 2015.

Dissertação (Mestrado)--Universidade de São Paulo, 2015.

1. SESI-SP. 2. Ensino. 3. Geografia I. Miranda, Maria Eliza. II. Título: SESI-SP: Rede, Sistema... e Nós? 
SILVA JR., Nabor Francisco da. Educação: o negócio do SESI-SP e as necessidades dos estudantes. Dissertação apresentada ao Programa de Pós-Graduação em Geografia Humana do Departamento de Geografia da Faculdade de Filosofia, Letras e Ciências Humanas da Universidade de São Paulo, para obtenção do título de Mestre em Geografia.

\section{Banca Examinadora}

Professor (a) Dr. (a): Maria Eliza Miranda (Orientadora)

Instituição:

FFLCH-USP

Julgamento:

Assinatura:

Professor (a) Dr. (a):

Instituição:

Julgamento:

Assinatura:

Professor (a) Dr. (a):

Instituição:

Julgamento:

Assinatura:

Professor (a) Dr. (a):

Instituição:

Julgamento:

Assinatura: 


\section{DEDICATÓRIA}

À Eliani, esposa e rocha firme, que sempre me apoiou incondicionalmente e ajudou a não desistir dessa empreitada.

Aos meus pais e irmãos que, mesmo distantes, têm parte do crédito pela forte presença em minha história acadêmica. 


\section{AGRADECIMENTOS}

Ao SESI-SP, na pessoa do diretor da Divisão de Educação e Cultura, Sr. Fernando Antonio Carvalho de Souza, pela autorização de acesso aos estudantes da instituição e às publicações de circulação interna, elementos fundamentais nos estudos preliminares e na concretização desse trabalho.

Aos amigos e amigas, em especial aqueles que trabalham ou trabalharam no SESI$\mathrm{SP}$, pelo estímulo e solidariedade.

À Prof ${ }^{a}$. Dr ${ }^{\mathrm{a}}$. Maria Eliza Miranda, pelo reconhecimento das demandas específicas desse trabalho e de minhas necessidades enquanto estudante, assim como pelo estímulo e atenção.

Aos diretores de escola e coordenadores pedagógicos da Rede Escolar SESI-SP, que divulgaram a pesquisa junto aos estudantes, sendo parceiros fundamentais na etapa de coleta de dados.

Aos estudantes, pela contribuição valiosa, com sua participação respondendo o questionário de coleta de dados. 


\section{EPÍGRAFE}

A dualidade estrutural da educação brasileira reproduziu as posições dos diferentes segmentos sociais na divisão social do trabalho atribuindo a alguns a possibilidade de exercer o pensar e o conceber, entendidos como reservados às atividades intelectuais e o fazer, o executar à grande maioria dos trabalhadores voltados para as atividades chamadas manuais.

Heloisa Santos, 2003, p. 157 


\section{RESUMO}

Este estudo procura apresentar e analisar os efeitos da relação entre os empresários do setor industrial e o Estado Nacional brasileiro sobre a oferta de serviços educacionais privados. Notadamente, a oferta desses serviços, por entidades mantidas pela indústria, mais, especificamente, por meio do Serviço Social da Indústria, Regional São Paulo que, ao longo de sua história, teve importante papel nas decisões acerca das políticas educacionais. A pesquisa bibliográfica indicou que os estudos sobre a Rede Escolar SESI-SP são pontuais e, frequentemente, omitem a relação entre o capital industrial e o poder público. Para trazer luz a essa questão recorreu-se à importante contribuição de DREIFUSS (1981). A análise dos dados da pesquisa empírica, revela que as transformações da sociedade e da própria Rede Escolar SESI-SP impactaram profundamente a relação entre esta última e os professores, levados a optar por jornadas de trabalho mais longas com reflexos, também, nas relações entre docentes e estudantes. Para obter esses dados foi disponibilizado um questionário na internet e enviado um convite a todas as escolas para que o divulgasse aos estudantes. As questões centrais, utilizadas aqui dizem respeito: 1 - às atividades desenvolvidas pelos professores que mais contribuem para a aprendizagem do estudante e, 2 - às ações e situações em sala de aula que dificultam a aprendizagem.

Palavras-chave: SESI-SP, Indústria, Ensino, Geografia, Bom professor 


\begin{abstract}
This study aims to present and analyze the effects of the relation between entrepreneurs of the industrial sector and the Brazilian National State on the provision of private educational services. Notably, the provision of these services by entities sponsored by the industry, more specifically, through the branch office of the Industrial Social Service in the state of São Paulo (SESI-SP), which, throughout its history, played a major role in decisions about educational policies. Research in literature indicated that studies on the SESI-SP School Chain are isolated and often omit the relation between industrial capital and the government. To bring light to this question, we resorted to the contribution of DREIFUSS (1981). The analysis of the empirical research data reveals that the transformation of society and the SESI-SP School Chain itself deeply impacted the relations between the latter and the teachers, who were led to opt for longer working hours with implications in the relationship among teachers and students. In order to collect the data, a questionnaire was available on the internet to be answered by the students. An invitation was sent to all schools with a recommendation to make all students informed of the questionnaire. The core issues, used here relate to: 1 - the activities carried out by teachers who contribute most to student learning, and 2 - to actions and situations in the classroom that hinder learning.
\end{abstract}

Keywords: SESI-SP, Industry, Teaching, Geography 


\section{LISTA DE FIGURAS}

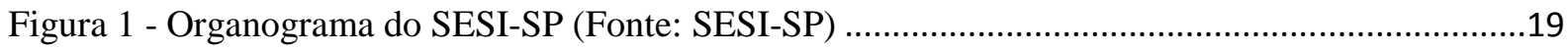

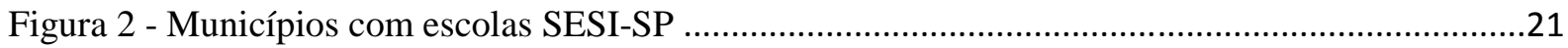

Figura 3 - Inauguração da Escola SESI de Bragança Paulista ............................................................22

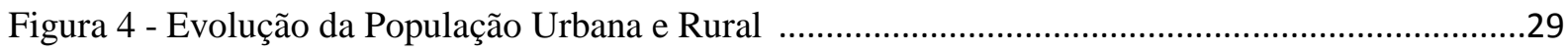

Figura 5 - Página do livro Movimento do Aprender $6^{\circ}$ ano - Geografia..............................................41

Figura 6 - Páginas do livro Movimento do Aprender - Geografia - $1^{\circ}$ ano do EM ................................43

Figura 7 - SARESP - Proficiência em Geografia ..........................................................................45

Figura 8 - Comparativo 2012 e 2013, da distribuição percentual dos estudantes em relação aos níveis

de proficiências em Língua Portuguesa no $7^{\circ}$ ano...........................................................................46

Figura 9 - Comparativo 2012 e 2013, da distribuição percentual dos alunos em relação aos níveis de

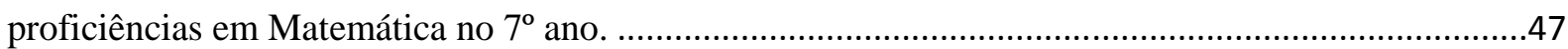

Figura 10 - Rede Escolar SESI-SP: Alunos pagantes e isentos - Fev/ 2014 .....................................50

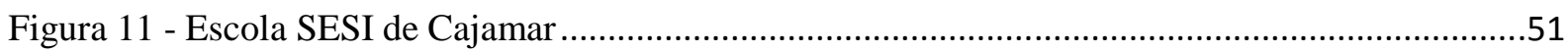

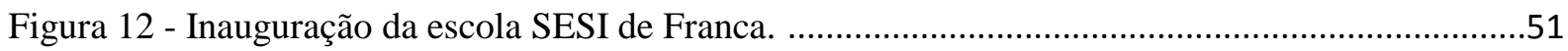

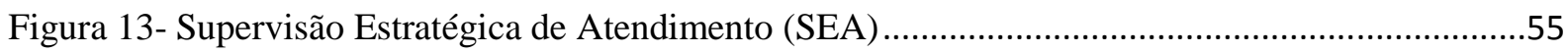

Figura 14 - Páginas do novo livro didático de Geografia - $6^{\circ}$ ano. ....................................................57

Figura 15 - Distribuição territorial dos municípios conveniados ao Sistema SESI-SP de Ensino .........61

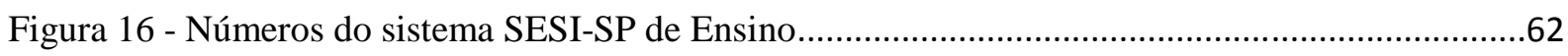

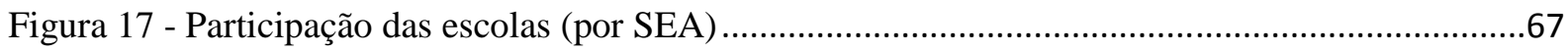

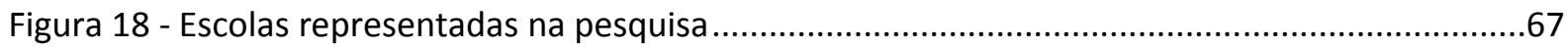

Figura 19 - Distribuição espacial das escolas representadas na pesquisa (por SEA) .............................68

Figura 20 - Quantidade de alunos participantes da pesquisa, por ano...............................................69

Figura 21 - Melhores professores que lecionaram no EF II no primeiro semestre de 2013, segundo os

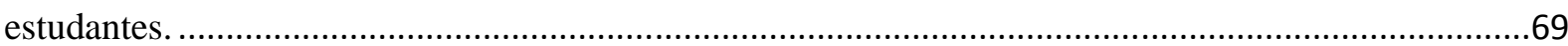

Figura 22 - Melhores professores que lecionaram no Ensino Médio no primeiro semestre de 2013,

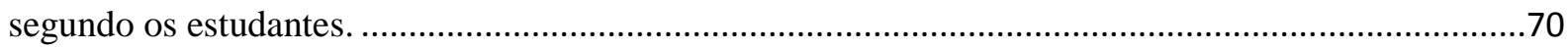

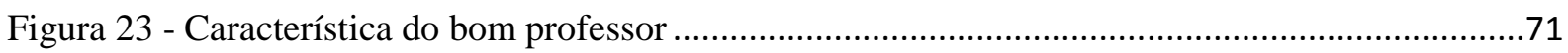

Figura 24 - Ações ou situações que atrapalham o aprendizado.........................................................72

Figura 25 - Atividades que, para os estudantes, favorecem o aprendizado. Dados agrupados por Regiões Administrativas do Estado de São Paulo, excluindo-se a Região de Registro onde não há

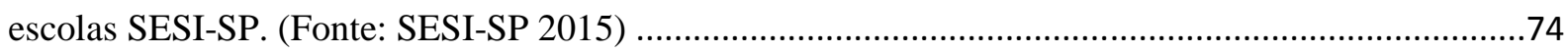

Figura 26 Importância do Ensino Médio para os estudantes do SESI-SP ..............................................77 


\section{LISTA DE QUADROS}

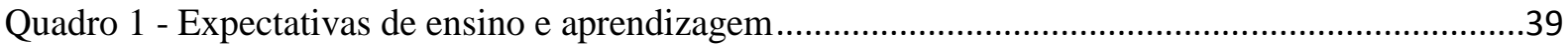

Quadro 2 - Prefeituras conveniadas ao Sistema SESI-SP de Ensino -2014 ……...............................60

Quadro 3 - SESI-SP - Escolas por nível de ensino ..........................................................................66 


\section{LISTA DE SIGLAS E ABREVIATURAS}

CNI - Confederação Nacional das Indústrias

CP - Coordenador Pedagógico

DE - Divisão de Educação

DEC - Divisão de Educação e Cultura

DN - Departamento Nacional

DR - Departamento Regional

EF - Ensino Fundamental

EJA - Educação de Jovens e Adultos

EM - Ensino Médio

FUNDEB - Fundo de Manutenção e Desenvolvimento da Educação Básica e de Valorização dos Profissionais da Educação

FUNDEF - O Fundo de Manutenção e Desenvolvimento do Ensino Fundamental e de Valorização do Magistério

GEB - Gerência de Educação Básica

INSS - Instituto Nacional de Seguridade Social

LDB - Lei de Diretrizes e Bases da Educação Nacional

MDE - Manutenção e Desenvolvimento do Ensino

SARESP - Sistema de Avaliação do Rendimento Escolar

SEA - Supervisão Estratégica de Atendimento 
SENAC - Serviço Nacional de Aprendizagem do Comércio

SENAI - Serviço Nacional de Aprendizagem Industrial

SENAR - Serviço Nacional de Aprendizagem Rural

SESC - Serviço Social do Comércio

SESI - Serviço Social da Indústria

SEST - Serviço Social de Transporte 


\section{SUMÁRIO}

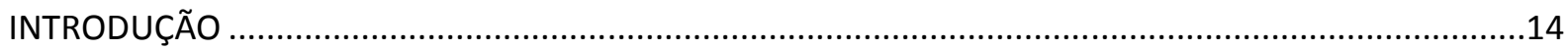

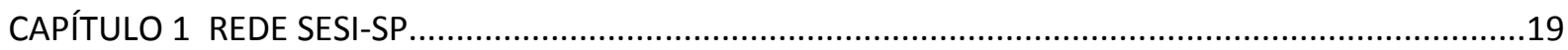

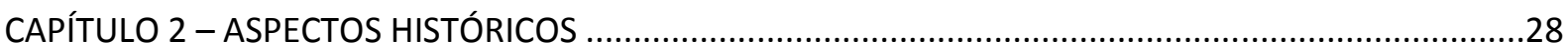

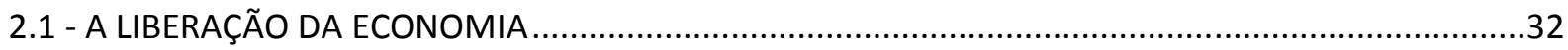

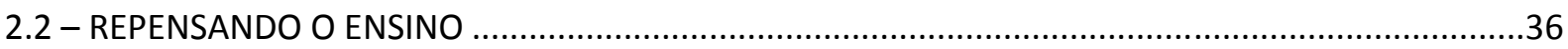

2.3 A REESTRUTURAÇÃO DA DIVISÃO DE EDUCAÇÃO: PREPARANDO O CAMINHO PARA A PRESTAÇÃO

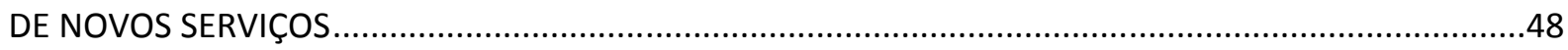

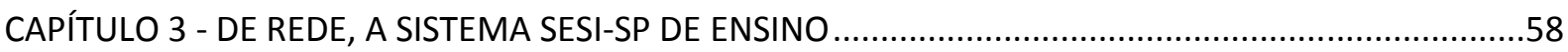

CAPITULO 4 O TRABALHO DOS PROFESSORES E O ENSINO DE GEOGRAFIA.........................................

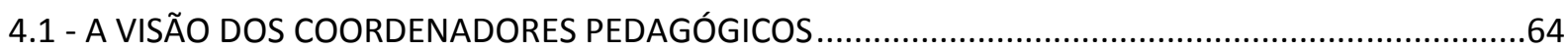

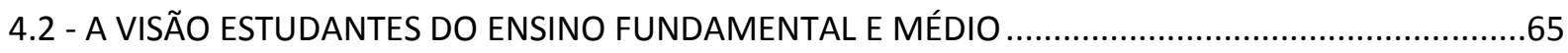

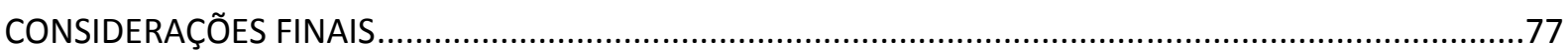

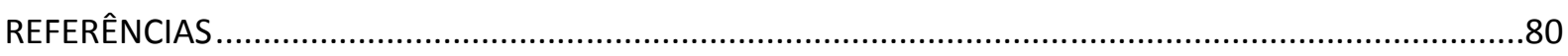

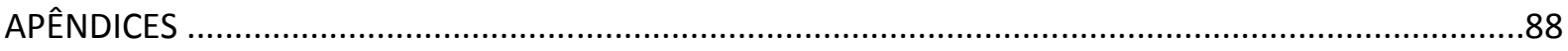

APÊNDICE 1 Pesquisa de opinião: Olhares sobre a prática docente na rede escolar SESI - SP .............88

APÊNDICE 2 Carta aos Administradores dos Centros Educacionais da Rede Escolar SESI-SP................91

APÊNDICE 3 TERMO DE CONSENTIMENTO LIVRE E ESCLARECIDO (Transcrição da solicitação) ............93

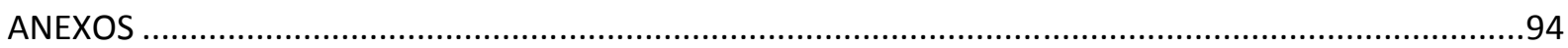

ANEXO 1 Pauta de Encontro de Formação de Professores do Ensino Fundamental II..........................94

ANEXO 2 Pauta de encontro de Formação de Professores do Ensino Médio .......................................95

ANEXO 3 RE- 02/2006 - Implanta o Ensino Fundamental de 9 anos, o Ensino Fundamental em tempo integra, o Ensino Médio Regular e o Ensino Médio Articulado com o SENAI .......................................98

ANEXO 4 - RE - 29/12 Altera a Estrutura Organizacional da Diretoria de Operações do SESI-SP ........99

ANEXO 5 RE - 11/13 Extingue vários órgãos e cria a Divisão de Educação e Cultura...........................100

ANEXO 6 Percepção dos Coordenadores Pedagógicos acerca da prática docente dos professores de Geografia 


\section{INTRODUÇÃO}

São recorrentes os questionamentos acerca da atuação do Serviço Social da Indústria (SESI) na educação, sobre sua organização ou a qualidade e objetivos do ensino oferecido, entre outras. Esse trabalho se propõe a apresentar e analisar algumas dessas questões e, também, incluir elementos que mostrem como as decisões tomadas ao longo da história do SESI-SP refletiram nas atuais relações de trabalho dos professores. Ou seja, como se tem construído a relação ensino-aprendizagem nas escolas do SESI-SP e quais os desdobramentos desse processo na perspectiva dos estudantes, à medida que a educação é tratada como um negócio? Em que medida ou até que ponto a percepção que os estudantes têm do trabalho de seus professores impacta no desempenho das escolas nas avaliações em larga escala?

É importante destacar que o SESI foi criado para atender as demandas de formação de mão de obra para a indústria e contribuir para o controle social das massas e das tensões entre trabalhadores e empregadores. Diante das transformações sociais pelas quais passou o país, como forma de efetivar as premissas que levaram à sua criação, passou por diversas transformações: da oferta de Educação para Jovens e Adultos e Educação Infantil à criação de cursos técnicos de nível médio e (a mais recente delas) de formação de professores em nível superior, que deve ter início em 2016; da manutenção de armazéns com abastecimento de produtos básicos aos trabalhadores da indústria à prestação de Serviços Educacionais a Redes Públicas Municipais; da organização de jogos entre operários ao incentivo e investimento em modalidades esportivas de alto rendimento e formação de público nas diferentes linguagens artísticas.

Notadamente, essas mudanças vêm ao encontro do discurso recorrente no interior da instituição que a identifica como "uma casa política". Isso porque, está atrelada aos interesses dos empresários da indústria em nível estadual e nacional, o que não descaracteriza a "vocação" de serviço à indústria, mas demonstra como a instituição seguiu os rumos da educação geral e, aparentemente, busca consolidar uma identidade diante da diversidade de demandas da sociedade contemporânea. Contudo, é necessário questionar se os recursos arrecadados pelos empregadores estão sendo utilizados para formar trabalhadores qualificados para as atuais demandas do mercado de trabalho, cada vez mais dinâmico e competitivo e às exigências do setor produtivo. 
Não raro, decisões que podem interferir diretamente na formação dos estudantes, são tomadas visando adequar a educação às necessidades de certos setores do empresariado representados por seus conselheiros ou, ainda, à exposição midiática que revela a escola como grande vitrine do comprometimento social da empresa. Isso porque, por ser a maior rede privada de ensino do estado de São Paulo, com mais de 100.000 estudantes, qualquer ação que envolva todas as escolas da rede se torna superlativa. Uma consequência dessa dimensão da rede é o uso político que dela é feito em diferentes escalas e vieses políticos.

Apesar disso, existem poucos estudos que têm por objeto o SESI-SP, embora sejam diversas as abordagens possíveis. Os estudos sobre instituições escolas, por exemplo, se concentram na

[...] história da instituição: sua criação, implantação e evolução. Há também estudos que recortam certos aspectos da instituição tais como: formação dos professores, evolução do currículo, experiências pedagógicas inovadoras, origem social da clientela escolar, trajetórias dos ex-alunos, valores professados, organização do espaço etc. (NOSELLA e BUFFA, 2013, p. 28)

Nessa perspectiva, é analisada ação dos industriais na organização do Sistema SESISP de Ensino e como as mudanças pelas quais passou, especialmente nos últimos 15 anos impactou o trabalho dos professores.

Como destaca Moura (2007, p. 7) "[...] chega-se à década de 30 do século XX com a Educação Básica brasileira estruturada de uma forma completamente dual na qual a diferenciação entre os percursos educativos dos filhos das elites e dos filhos da classe trabalhadora ocorria desde o curso primário".

Mas, para a elite que pagava pelos estudos de seus filhos, a garantia de ensino universal, como preconizavam os educadores que assinaram o Manifesto dos Pioneiros ${ }^{1}$, não fazia sentido. Apesar disso, o Manifesto influenciou contundentemente a educação brasileira.

Destaca-se, ainda que à época:

Campanhas lideradas pela ABE (Associação Brasileira de Educação) puderam reunir sob o mesmo movimento alguns representantes de ideologias conflitantes da época como positivistas, católicos e liberais. Havia uma percepção do progresso com fator de desagregação dos valores tradicionais e a ameaça de dissolução da ordem social caso não houvesse o preparo das elites políticas e econômicas. Estas assumiriam o seu papel condutor no sentido de atenuar os conflitos de classe, lidando com as questões de ordem moral, saúde e adequação do operário às exigências do capitalismo industrial (CARVALHO, 2011, p. 21-22).

\footnotetext{
${ }^{1}$ Manifesto dos Pioneiros da Educação Nova (1932), elaborado por Fernando de Azevedo
} 
Conforme destaca Cunha (2005, p. 7):

Reforçando a dualidade escolar, a política educacional do Estado Novo erigiu uma arquitetura educacional que ressaltava a sintonia entre a divisão social do trabalho e a estrutura escolar, isto é, entre o ensino secundário, destinado às "elites condutoras", e os ramos profissionais do ensino médio, destinados às "classes menos favorecidas", embora os alunos desses ramos devessem ser selecionados. Ou seja, a pobreza ou o "menos favorecidos" poderia ser condição conjuntural, mas não era suficiente para o ingresso num curso profissional.

A separação entre o ensino para a elite e para as classes trabalhadoras, entre a formação para o pensar e para o fazer se fortaleceu com a criação do Serviço Nacional de Aprendizagem Indústria (SENAI)) pelo Decreto-Lei n ${ }^{\circ} 4.048$ de 22/01/1942 e do Serviço Social da Indústria (SESI), pelo Decreto-Lei No 9.403, de 25 de junho de 1946, assim como, posteriormente, de outras entidades, como o Serviço Social do Comércio (SESC) e o Serviço Nacional de Aprendizagem do Comércio (SENAC); e, já nos anos '90, o Serviço Nacional de Aprendizagem Rural (SENAR) e Serviço Social de Transporte (SEST), contribuiu para ampliar ainda mais essa dualidade que ainda persiste no modelo educacional brasileiro.

Para o desenvolvimento desse trabalho optou-se por ter como recorte de análise optouse por desenvolver a pesquisa no âmbito do SESI-SP por ser, entre as organizações do Sistema S, a com a maior rede de escolas de Educação Básica. Além disso, está vinculada a um setor da sociedade que, desde a década de 40, influencia a política nacional, estando profundamente entrelaçado nas mais altas esferas de comando e, em 2013, geriu um orçamento de $\mathrm{R} \$$ $1.919 .869 .964,00^{2}$.

Destaca-se, inicialmente, que foi constatado que, no Sistema SESI-SP de Ensino, a Educação Básica está convergindo para uma proposta comum de formação geral, ainda que esteja fazendo esforços no sentido de incentivar a formação técnica-profissionalizante de Nível Médio ao oferecer esses tipos de curso. Isso acontece porque, essa perspectiva está em desacordo com o que esperam os estudantes da rede. Além disso, deixa claro que muitos problemas comumente atribuídos às escolas públicas, a começar pelos índices de aproveitamento escolar, mas, também, falta de professores, indisciplina, entre outros, também afetam as escolas SESI-SP.

No que diz respeito à pesquisa realizada, é oportuno dizer que a etapa de coleta de dados, realizada junto aos estudantes da Rede SESI-SP de Ensino, foi feita por meio de um

\footnotetext{
${ }^{2}$ Conforme Diretrizes Orçamentárias disponíveis em http://www.sesisp.org.br/lei-de-diretrizes-orcamentarias. Acesso em: 20 de Mai. 2015
} 
questionário com perguntas fechadas e abertas, elaborado a partir das funcionalidades da Web $2.0^{3}$ e ficou disponível para ser acessado pela Internet de 9 de setembro a 11 de outubro de 2013. Esta foi considerada a técnica mais adequada por permitir focar a pesquisa em algumas variáveis que a serem analisadas e possibilitar o acesso a todos os estudantes do Ensino Fundamental II (EF II), que corresponde aos $6^{\circ}, 7^{\circ}, 8^{\circ}$ e $9^{\circ}$ anos e do Ensino Médio da Rede Escolar SESI-SP.

Como indicam Schiavoni e Martinelli (2005, p. 311), em geral as pesquisas envolvendo estudantes "têm se preocupado em investigar a questão de seus sentimentos $e$ crenças, auto percepção, autoconceito, autoestima e auto eficácia, por meio da declaração dos mesmos".

Por mais que se valorizem os resultados de avaliações em larga escala, os estudantes são os principais sujeitos do processo de ensino e aprendizagem, ou melhor, é ele quem está mais apto a emitir um valor ou dimensionar o que está aprendendo e que tipo de ações contribuem para esse aprendizado. Daí a importância de ouvi-los. Nesse sentido, como indica Vigotski:

[...] a verdadeira comunicação humana pressupõe uma atitude generalizante, que constitui um estágio avançado do desenvolvimento da palavra. As formas mais elevadas da comunicação humana somente são possíveis porque o pensamento do homem reflete uma realidade conceitualizada. (VIGOSTKI, 1987, p. 5)

O questionário utilizado para coleta de dados (APÊNDICE 1) é composto por um conjunto de quatro (4) questões objetivas (fechadas) e duas (2) abertas, sendo que uma delas está subdividida em três itens. Apesar de podermos identificar a escola onde os estudantes estão matriculados, tomou-se o cuidado de preservar sua identidade (sem solicitar nomes). Para estruturar o questionário, disponibilizá-lo aos participantes e visualizar as respostas em tempo real, coletar e sistematizar os dados fez-se uso das funcionalidades da Web 2.0, como indicado anteriormente, mais especificamente do Google Drive ${ }^{4}$.

Os estudantes foram convidados a participar da pesquisa por meio de carta enviada aos Administradores dos Centros Educacionais (APÊNDICE 2) via note (programa de e-mails utilizados pelo SESI-SP), sendo que a participação era voluntária e não houve sugestão de onde ou em que momento responder ao questionário.

\footnotetext{
${ }^{3}$ Cf. http://www.significados.com.br/web-2-0/ Acesso em 20 de Jan. 2014.

${ }^{4}$ Google Drive é o serviço de disco virtual. Possui aplicativos que possibilitam a criação de questionários e permite o armazenamento e compartilhamento de arquivos na nuvem do Google.
} 
O contato com as escolas foi precedido de uma conversa com a gerente de Currículos e Programas, professora Anaide Trevizan e envio de "Termo de Consentimento Livre e Esclarecido" ao Diretor da Divisão de Educação do SESI-SP, professor Fernando Antonio Carvalho de Souza (APÊNDICE 3).

Finalmente, destaca-se que este trabalho está estruturado em quatro capítulos. No primeiro deles apresenta-se um panorama atual da Educação Básica oferecida pelo SESI-SP, sua distribuição territorial e resultados de avaliações externas de larga escala.

A partir dessa exposição inicial, no segundo capítulo, são considerados aspectos históricos que levaram à criação do Serviço Social da Indústria, indicados os estudos a seu respeito e algumas das mudanças organizacionais pelas quais passou a atual Divisão de Educação e Cultura (DEC) que levaram à atual configuração da Educação Básica na rede. Esta configuração do Sistema SESI-SP de Ensino é abordada no terceiro capítulo, onde se destacam algumas motivações para sua criação, como aspectos legais e financeiros. Já, no quarto capítulo são apresentados dados da pesquisa realizada junto aos estudantes que evidenciam importantes reflexos das condições de trabalho na atuação dos professores, com destaque para os de Geografia. 


\section{CAPÍTULO 1 REDE SESI-SP}

O objetivo desse capítulo é apresentar um panorama atual da Educação Básica oferecida pelo SESI-SP, sua distribuição territorial e resultados de avaliações externas de larga escala, tomando como referência resultados do Sistema de Avaliação do Rendimento Escolar (SARESP).

O Serviço Social da Indústria (SESI) tem uma estrutura administrativa descentralizada. Assim, apesar de ter como órgão de comando principal o Departamento Nacional (DN), cada estado e o Distrito Federal têm seus Departamentos Regionais (DR) e Conselhos Regionais, de caráter respectivamente administrativo e Normativo. Além disso, é supervisionado pela Confederação Nacional das Indústrias (CNI). Em função dessa descentralização, cada Departamento Regional traça suas prioridades de ações em consonância àquelas definidas pelo Departamento Nacional o que confere caraterísticas distintas a cada um deles. Em alguns são priorizadas as atividades de lazer, em outros, o atendimento ao trabalhador ou, ainda, a Educação Básica.

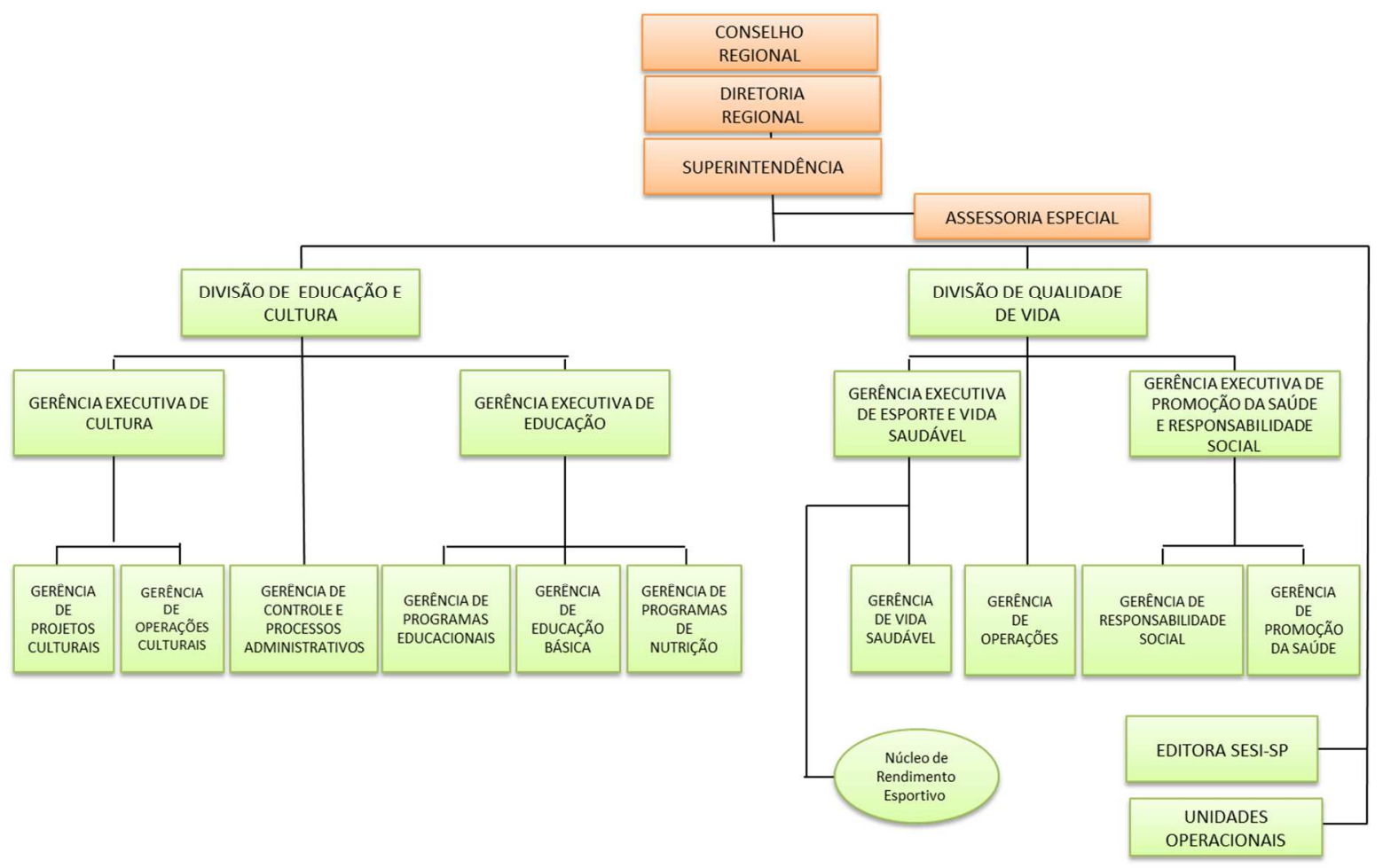

Figura 1 - Organograma do SESI-SP (Fonte: SESI-SP) 
No estado de São Paulo o SESI tem supervisão própria, delegada pela Secretaria Estadual de Educação, desde 1995 que, além de conferir maior autonomia administrativa, ao SESI-SP, de modo a acelerar seus processos e a própria fiscalização de suas escolas, de certa forma, fechou as portas para ingerências de agentes externos em relação às medidas que seriam tomadas no processo de reestruturação pelo qual viria a passar.

O SESI-SP tem promovido alterações no trabalho com os estudantes (assim como na Rede Estadual de Ensino do Estado de São Paulo), vislumbrando manter-se atualizado diante das demandas da sociedade e da conjuntura econômica, pois esta última reflete nos recursos arrecadados pela instituição. Isso pode ser percebido no fato de possuir material didático próprio para o Ensino Fundamental e Ensino Médio e também participar do SARESP.

Entretanto, a atenção especial que se dá à proficiência dos estudantes em avaliações como essa, pode ser interpretada como uma visão tipicamente alinhada à aplicação do modelo tecnicista neoliberal aplicado à educação de forma a legitimar a ordem econômica e social vigente.

Deve-se destacar, ainda, que a comparação desses dados com os de outras redes tem sido utilizada como forma de enfatizar os resultados dos investimentos realizados com recursos do Salário Educação e, também, reforçar a imagem de boa administração desses recursos. Já, em âmbito local, nos municípios, principalmente do interior, é uma estratégia utilizada para atrair estudantes a cursarem o Ensino Médio.

Em São Paulo, por exemplo, esses recursos têm como principal destino as ações voltadas para Educação Básica (no Ensino Fundamental, Médio e Educação de Jovens e Adultos) e para a prática de atividades físicas. Com isso, o Departamento Regional de São Paulo é o que mais investe em educação, mantendo 175 escolas (a maior rede de ensino privado no Estado de São Paulo) com Ensino Fundamental e Ensino Médio distribuídas em 111 municípios. (Figura 2). 


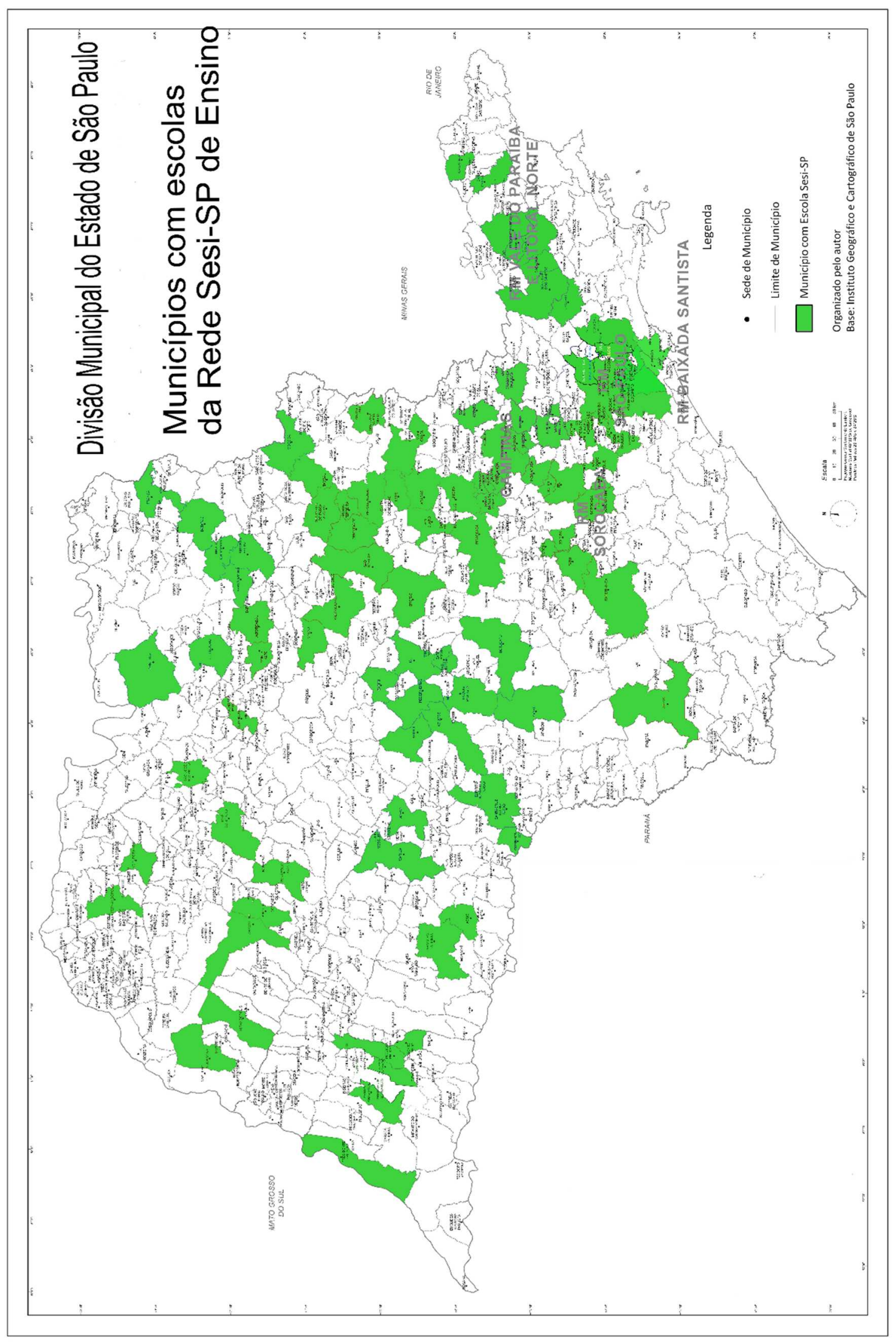

Figura 2 - Municípios com escolas SESI-SP 
Nos últimos anos, entre os investimentos em educação, destacam-se aqueles destinados à renovação tecnológica, reforma e construção de novas escolas (Figura 3), muitas delas para acomodar unidades escolares que até então funcionavam em prédios mantidos através de convênios com prefeituras e entidades religiosas, as quais, uma vez ampliadas, também demandaram mais investimento em mão de obra. Segundo informações no site do SESI-SP, de 2007 a 2014, "o total de recursos empregados na modernização da educação e adaptação da rede de unidades escolares chegou a $R \$ 2,4$ bilhões".

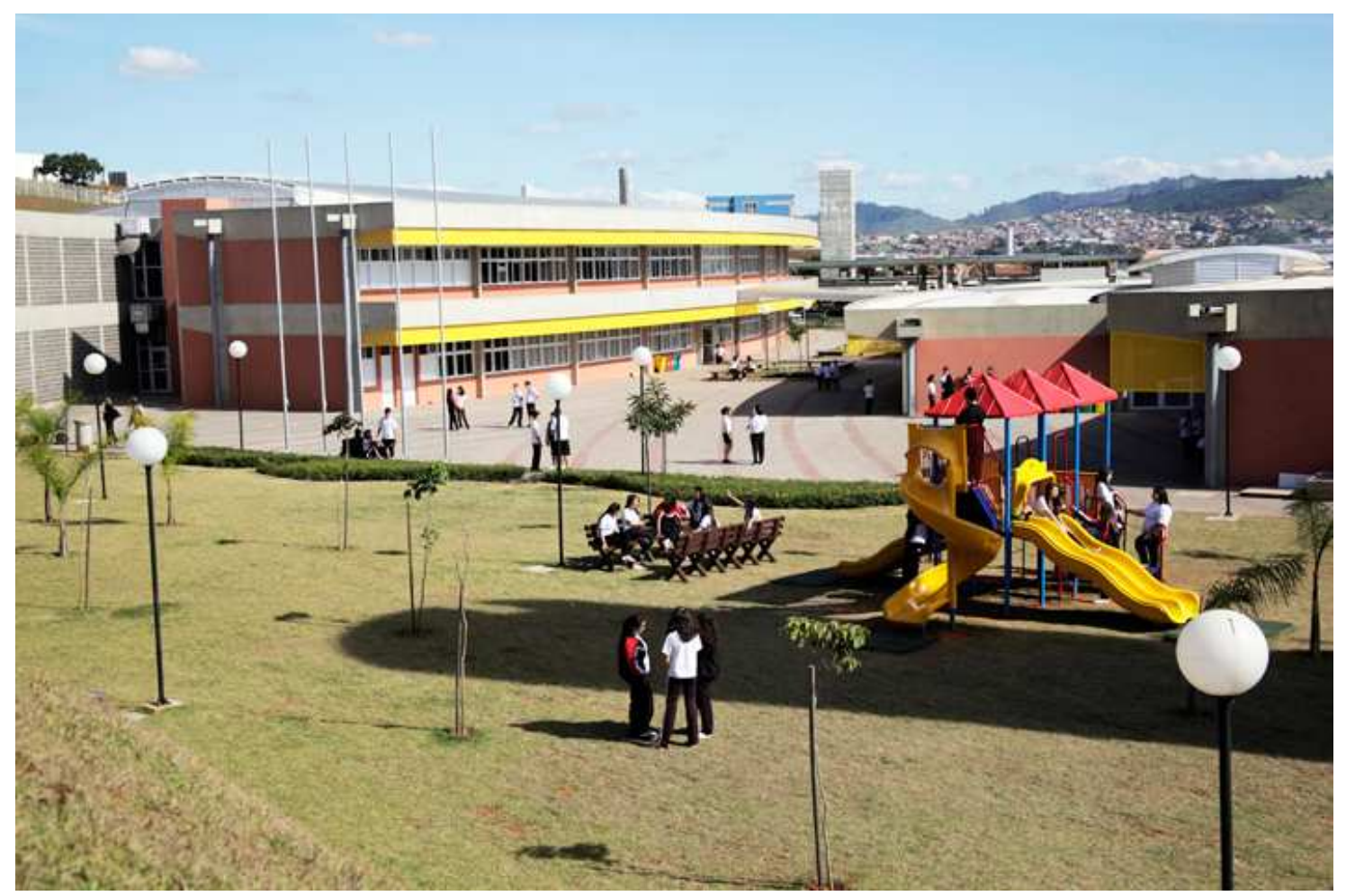

Figura 3 - Inauguração da Escola SESI de Bragança Paulista

Fonte: http://wvicioni.com.br/galleries/inauguracao-escola-SESI-de-braganca-paulista/

Além disso, os dados das avaliações externas, sobretudo o SARESP, são constantemente retomados visando subsidiar a formação continuada dos gestores e dos professores, pois, apesar de serem resultados bons, se comparados com a rede pública estadual, demonstram a necessidade de promover avanços uma vez que apenas uma pequena parte das escolas têm estudantes com nível de proficiência avançado em qualquer dos componentes curriculares avaliados.

Essa comparação com a Rede Estadual de Ensino tem um componente político, inclusive utilizado nas eleições para o governo do estado. Por outro lado, também, estabelecer um parâmetro de comparação para justificar os investimentos realizados. Evidentemente, esse parâmetro poderia ser o desempenho de escolas com auto rendimento, mas isso não é feito. 
É importante considerar, também, que a implementação gradual do ensino de 9 anos e da escola em tempo integral, a substituição da organização do Ensino Fundamental em ciclos de dois anos, pelo ensino seriado e a implementação do material didático próprio e sua revisão, em parte, são ações implementadas para: 1 - atender à legislação e, 2 - responder às demandas da sociedade, principalmente dos beneficiários da indústria.

Isso demonstra que as transformações pelas quais a sociedade tem passado são incorporadas dela Rede SESI-SP como forma de "manter-se viva" em um mercado cada vez mais competitivo o que impacta no cotidiano das escolas, em sua organização e em seus sujeitos, como professor e estudantes. Ou, mais que isso, que o SESI-SP reproduz o modelo de educação tecnicista neoliberal em vigor no país.

As transformações cada vez mais rápidas da sociedade são desafiadoras para as relações de ensino e aprendizagem desenvolvidas na escola. Com destacam Libâneo e Pimenta (2002, p. 40):

$\mathrm{Na}$ sociedade contemporânea, as rápidas transformações no mundo do trabalho, o avanço tecnológico configurando a sociedade virtual e os meios de informação e comunicação, incidem com bastante força na escola, aumentando os desafios para torná-la uma conquista democrática efetiva. Não é tarefa simples, nem para poucos. Transformar as escolas em suas práticas e culturas tradicionais e burocráticas que (através da retenção e da evasão) acentuam a exclusão social, em escolas que eduquem as crianças e jovens propiciando-lhes um desenvolvimento cultural, científico e tecnológico que lhes assegure condições para fazerem frente às exigências do mundo contemporâneo, exige esforço do coletivo da escola - professores, funcionários, diretores e pais de alunos - dos sindicatos, dos governantes e de outros grupos sociais organizados.

Com isso, a escola ganha cada vez importância. Segundo Ferreira (2010, p. 67 - 68)

A generalização da compreensão da relevância social da escola deve-se em boa parte à aceitação da sua especial eficácia para o desenvolvimento de uma ordem cultural mais consentânea com a modernidade. Ela mostrou-se mais adequada que qualquer outra instituição às exigências de formação requeridas por uma sociedade cada vez mais marcada por uma dinâmica econômica capitalista e por uma burocracia administrativa cada vez mais controladora e sofisticada; ela revelou-se especialmente interessante à configurações político-ideológicas empenhadas em difundir e consolidar uma cultura que promovesse a coesão entre indivíduos de grupos sociais diversos com interesses diversificados ou até antagônicos, estabelecesse uma sintonia ou pelo menos a compreensão/ aceitação de princípios e de normas sociais orientadoras das relações entre diferentes níveis de hierarquias e, principalmente, que permitisse estabelecer a identificação de princípios civilizacionais entre a base e o topo da sociedade.).

Como exemplo da importância da escola, o trabalho de REPA (2008), com estudantes egressos da escola SESI - Vila Cisper em São Paulo - SP, destaca a importância da instituição 
para o sucesso desses ex-alunos e, nas falas dos entrevistados, se percebe, também, que para as famílias, de modo geral, a escola fez a diferença na vida dos estudantes. Segundo o autor,

[...] podemos verificar que o SESI - Vila Cisper serve de referência educacional para as famílias oriundas das classes menos favorecidas da nossa sociedade. Mas, além desses objetivos, esses egressos demonstram que estudar na entidade possibilitava-lhes conquistar dignidade e respeito, abrindo-lhes caminhos e perspectivas. (REPA, 2008, p. 83)

Um dos sujeitos entrevistados destaca:

A vida da minha família sempre esteve ligada ao SESI. Minhas duas irmãs mais velhas também estudaram aqui. Uma se formou em Pedagogia e a outra assim como eu é Advogada. Hoje, nós temos um escritório de advocacia. Eu acho que o que a gente aprendeu aqui nós levamos pela vida inteira. Tenho muita saudade da escola e principalmente dos professores, aqui a gente tinha vontade de estudar e aprender. Eu sinceramente acho que o SESI foi a base da minha vida. (REPA, 2008, p. 82)

Outro deles, afirma que

[...] O SESI me ajudou muito a entrar na faculdade. Meus pais têm muita saudade do SESI. Eles consideram todo o meu sucesso como decorrência do SESI. Se eu tiver filhos com certeza vou coloca-los para estudar no SESI, pois quando eu cursei o Ensino Médio, muito do que era passado eu já tinha visto no SESI e isso me ajudou bastante. (REPA, 2008, p. 82)

Outro aspecto importante do trabalho de REPA é que a maior parte dos professores com filhos em idade escolar tinha filhos estudando na unidade onde a pesquisa foi desenvolvida e, três dos professores estudaram na escola.

\section{2 - O TRABALHO DO PROFESSOR}

As transformações na sociedade relacionadas ao avanço das Tecnologias da Informação e da Comunicação também tem provocado modificações no papel da escola, e nas relações e condições de trabalho em seu interior, o que também se aplica ao SESI-SP.

Conforme destaca Alves (2009, p.35)

No que diz respeito ao lugar ocupado pelos professores na divisão técnica do trabalho, nas tarefas que realizam em suas atividades, é evidente o fato que o trabalho docente vem a cada dia expressando menos autonomia, maior divisão, intensificação e fragmentação. 
Apesar disso, é possível afirmar que se está formando uma cultura na qual o professor é "mais um" funcionário que deve apenas cumprir as tarefas para as quais é pago. Mas, as tarefas e desafios que lhes impõem a escola vão muito além da docência.

Esse processo de intensificação e fragmentação do trabalho do professor aponta para a observação de BECKER (2002) que destaca o caráter fundamentalmente empírico da docência nos diversos níveis de ensino e a relevância que os professores dão a essa experiência, mais que a reflexão sobre ela.

Como as instituições privadas como o SESI-SP, especificamente, lidam ou valorizam esses saberes, essas experiências? Existem mecanismos para proporcionar o aprofundamento das reflexões sobre o fazer pedagógico ou o professor é tratado como mero executor de tarefas, um profissional que está ali apenas para dar aulas?

Na rede SESI-SP esses mecanismos consistem no acompanhamento do professor pelo coordenador pedagógico e em reuniões semanais de estudo com todos os professores do Ensino Fundamental I (EF I) (professores do $1^{\circ}$ ao $5^{\circ}$ ano e estagiários). Os professores do Ensino Fundamental II (EF II), (6 $6^{\circ}$ ano $9^{\circ}$ ano), e do Ensino Médio (EM) também participam desse horário de estudos, mas somente aqueles com carga horária de 40 horas semanais.

Ressalta-se aqui, a importância de momentos organizados na escola, acompanhados pelo coordenador pedagógico, que promovam a reflexão sobre a prática docente, por exemplo, ou, com estudos e discussões sobre problemas do cotidiano da sala de aula e os contextos em que eles ocorrem. Esses momentos, além de favorecer o aprimoramento da prática docente, podem contribuir para um trabalho mais integrado da equipe, de forma mais colaborativa, fortalecendo o profissional para um melhor desenvolvimento de suas atribuições individualmente, mas também promovendo uma forma de atuar mais coletiva. Mas, isso não é corroborado pelos dados da pesquisa realizada, uma vez que as respostas dos estudantes apontam para aspectos da prática docente e das relações de ensino e aprendizagem que poderiam discutidos e resolvidos nesses momentos.

Nesse sentido, Fullan e Hargreaves (2000, p. 71), destacam que "a simples existência de colaboração não dever ser confundida com a consumação de uma cultura de colaboração". E, além disso, as "culturas de colaboração são incompatíveis com sistemas escolares nos quais as decisões sobre o currículo e a avaliação são fortemente centralizados" (HARGREAVES, 2001, p. 217). 
Uma ação de formação realizada pela instituição ocorre anualmente quando é organizado um encontro denominado Saber em Ação, onde os professores assistem palestras com especialistas, participam de oficinas e socializam experiências, as quais são publicadas. Para possibilitar a participação de todos, considerando que há escolas distribuídas por todo o Estado, professores e gestores se reúnem em polos na capital e no interior, em salas com equipamentos para teleconferência e interagem à distância com os palestrantes.

Percebe-se, então, que existe uma política institucional voltada para a formação dos professores que, conforme destaca Saviani (2001, p.12), procura "planejar a educação de modo a dotá-la de uma organização racional capaz de minimizar as interferências subjetivas que pudessem pôr em risco sua eficiência".

Vem, ainda, de encontro do que afirmam LIBÂNEO e PIMENTA (2002, p. 41):

Entretanto, é preciso que as políticas de formação contínua de professores estejam articuladas a um processo de valorização identitária e profissional dos professores. Identidade que é epistemológica, ou seja, que reconhece a docência como um campo de conhecimentos específicos configurados em quatro grandes conjuntos, a saber: conteúdos das diversas áreas do saber e do ensino [...]; conteúdos didáticopedagógicos (diretamente relacionados ao campo da prática profissional); conteúdos relacionados a saberes pedagógicos mais amplos (do campo teórico da prática educacional); conteúdos ligados à explicação do sentido da existência humana.

Para podermos visualizar plenamente o cenário indicado acima, de "valorização identitária e profissional do professor" é preciso que as políticas de desenvolvimento do ensino busquem com mais veemência a valorização dos profissionais da educação, em especial dos professores, oferecendo melhores condições de trabalho, não apenas físicas, mas organizacionais, como tempo para estudo e análise de produções dos estudantes, para preparação de materiais didáticos e de atividades diversificadas, para reflexão e diálogo com seus pares a respeito da aprendizagem dos estudantes.

Um modelo que pode contribuir para a concretização do exposto acima, e pode ser utilizado como referência, é o que está sendo gradualmente implantado é o regime de trabalho dos professores das escolas em tempo integral da rede pública estadual de São Paulo. Nesse modelo os professores têm acréscimo de $75 \%$ em seu salário e trabalham em regime de dedicação plena e integral à unidade escolar, oito horas por dia, mas considerando a seguinte organização:

O exercício da docência em disciplinas da base nacional comum e da parte diversificada e/ou das atividades complementares deve respeitar o limite máximo de 28 horas-aula para docente e 16 horas-aula para docente que exerce coordenação de área na atribuição regular das aulas na unidade do programa. Dessa forma, garante-se o mínimo de 4 horas aula sem atribuição, 
até o limite de 32 horas-aula, em que fica à disposição da escola para substituição e outras atividades pertinentes. (SÃO PAULO, 2014, p. 6)

Nas escolas que já aderiram ao novo modelo proposto pela Secretaria Estadual de Educação são tomadas medidas para que os estudantes não tenham aulas vagas. Além disso, eles passam mais tempo em atividades educativas, seja nas disciplinas da base nacional comum, desenvolvendo seu projeto de vida ou em disciplinas eletivas, oferecidas a partir de decisão coletiva da escola e, como indicado acima, parte das atividades dos professores se dá em outras atividades, além do trabalho com as disciplinas da base nacional comum.

Em uma dessas escolas, a título de exemplo, os resultados já podem ser percebidos:

\section{Evolução da proficiência em Língua Portuguesa}

\begin{tabular}{cccc}
\hline Nível & $\mathbf{2 0 1 2}$ & $\mathbf{2 0 1 3}^{*}$ & $\mathbf{2 0 1 4}$ \\
\hline Abaixo do Básico & 50 & 17,6 & 10,7 \\
\hline Básico & 32,8 & 52,0 & 21,4 \\
\hline Adequado & 17,2 & 29,4 & 67,9 \\
\hline Avançado & 0,0 & 0,0 & 0,0 \\
\hline
\end{tabular}

Quadro 1- SARESP 2014 - Proficiência em Língua Portuguesa - E.E. Professor Milton da Silva Rodrigues

*Ano do início no projeto de escola integral

Vê-se que, apesar dos estudantes não terem atingido o nível avançado, o aumento da concentração no nível adequado, entre 2013 e 2014 é superior ao dobro e quatro vezes maior que a concentração de estudantes neste nível em 2012 quando a escola funcionava em regime parcial. 


\section{CAPÍTULO 2 - ASPECTOS HISTÓRICOS}

O objetivo deste capítulo é apresentar elementos que contextualizem o processo de industrialização e das transformações políticas e socioeconômicas nacionais a partir dos anos '20 do século passado e início do século XXI que influenciaram a proposta de educação implementada, a partir do ano 2000, nas unidades escolares do Serviço Social da Indústria no Estado de São Paulo (SESI-SP).

A década de vinte, do século passado é um marco nesse processo, pois viu a formação de novos centros comerciais no Brasil, segundo Dreifuss (1981) levando ao deslocamento do poder político do nordeste agrícola e comercial para a Região Sudeste e das oligarquias rurais para a crescente elite urbana, sobretudo ligada aos setores financeiro e industrial.

Como exemplo, destaca-se o caso do Estado de São Paulo onde, de 1920 a 1928 a indústria cresceu, em média, 6,6\% ao ano, enquanto a média nacional foi de 3,3\% a.a.. Nesse período, a "concentração industrial em São Paulo aumentava, dos 31,5\% do total nacional em 1919 para 37,5\% em 1929” (CANO, 2012, p. 82).

Segundo Patarra (2003) o período compreendido entre 1930 e 1940 é marcado pela consolidação do desenvolvimento industrial, ainda que concentrado, no Brasil.

É importante destacar, também, que essas mudanças, principalmente de ordem econômica, refletiram na expansão do mercado de trabalho, surgimento de novas carreiras e na ampliação do mercado consumidor. Com isso, e devido à aceleração do êxodo rural, a educação escolar passou a ser uma importante via de inserção social. 


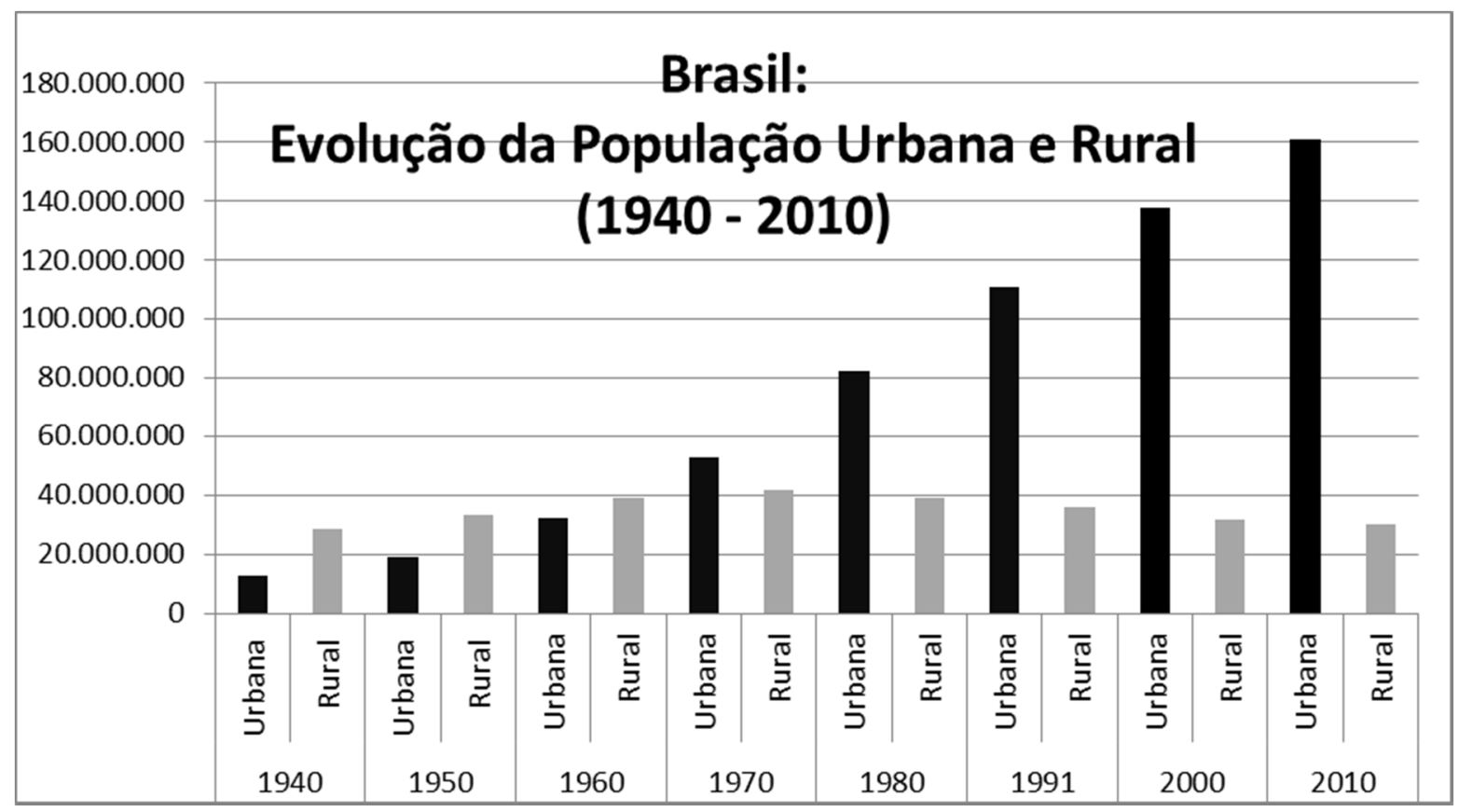

Figura 4 - Evolução da População Urbana e Rural (Fonte: IBGE)

Segundo Dreifuss (1981, p. 21), a "urbanização e o desenvolvimento industrial exerceram efeito desorganizador sobre a frágil estrutura do estado oligárquico”. Com isso, a burguesia industrial se organizou em um bloco para lutar pela redefinição das relações de poder dentro do Estado brasileiro.

Durante o primeiro governo de Getúlio Vargas (1930-1934), as relações entre a indústria e o setor agroexportador foram marcadas por uma coexistência difícil devido aos conflitos de interesses setoriais e dificuldade de, estando no poder, representar o "conjunto dos interesses econômicos privados 5 ".

Nesse período os industriais já se encontravam organizados em Associações Setoriais as quais, a partir de então, seguindo determinação do governo ${ }^{6}$, seriam chamadas de sindicatos ou federações considerando sua abrangência (local ou nacional). Esses sindicados, inclusive os de trabalhadores, precisariam ser aprovados pelo do Ministério do Trabalho, Indústria e Comércio e se submeterem ao seu controle. Esse processo histórico e seus desdobramentos foram destacados pelo trabalho de Gumiero (2002) no qual a autora apresenta a cronologia de criação de associações e ligadas à indústria e, enfatiza o caso do SESI-SP e a participação do

\footnotetext{
${ }^{5}$ DREIFUSS, 1981, loc. cit.

${ }^{6}$ A primeira legislação sindical da década de 1930 foi o Decreto-Lei no 19.770 de 19 mar.1931. Com o advento do Estado Novo, o movimento sindical foi atrelado ao governo passando a ser controlado por ele.
} 
empresariado na constituição de entidades assistenciais, sindicatos patronais e nas reformas educacionais.

Em relação ao SESI, a referida autora descreve as mudanças organizacionais na instituição do que se tornaria atualmente a Divisão de Educação e Cultura (DEC) e apresenta a evolução das atividades voltadas para o atendimento de seu público alvo (trabalhadores da indústria e seus dependentes, mas também à comunidade em geral), principalmente quanto à educação e organização do currículo. Apesar disso, não aponta as relações desse processo de desenvolvimento com o contexto político e econômico brasileiro, considerando principalmente os aspectos relacionados à legislação educacional.

Desse histórico é fundamental destacar que o Centro das Indústrias do Estado de São Paulo (CIESP) foi a primeira Associação Industrial a se sindicalizar, conforme orientações do Governo Federal. Três meses depois da publicação do decreto n ${ }^{\circ} 19.770$, formou-se a Federação das Indústrias do Estado de São Paulo (FIESP).

A FIESP desenvolveu intensa campanha para a obtenção de sócios [...] apontava para os riscos gerados pela intensa sindicalização operária então em curso, que terminaria por colocar o setor dos empregadores não sindicalizados em situação de inferioridade (GUMIERO, 2002, p.35).

Organizadas em nível federal, as instituições industriais, propuseram modificações na legislação sindical. A mais importante delas foi a diferenciação entre os sindicatos operários e os patronais, sendo que estes últimos passaram a ser considerados órgãos consultivos com representantes nos principais conselhos econômicos do governo.

O golpe de Estado que deu início ao período conhecido como Estado Novo (19371945) liderado por Getúlio Vargas, veio ao encontro das demandas dos industriais, pois contribuiu para sufocar os movimentos sindicais, principalmente colocando-os sob o controle estatal. Nesse período a articulação entre sociedade civil e Estado se torna mais evidente e as organizações privadas passam a ter relações mais estreitas com o Estado, colaborando na elaboração de políticas e se beneficiando com essa proximidade. Conforme afirmam Oliveira e Ferreira (2008, p. 35):

Entre os pressupostos da estratégia neoliberal para a área social, encontramse os instrumentos de intervenção pública marcados pela concentração dos recursos destinados à população mais carente, pelo repasse de parte dos fundos públicos ao setor privado e pela descentralização das ações.

Nessa perspectiva, por solicitação do Governo, o setor industrial criou em 1942, o Serviço Nacional de Aprendizagem Industrial (SENAI) e, em 1946 (durante o governo do 
General Eurico Gaspar Dutra), o Serviço Social da indústria (SESI), um serviço de assistência social e de educação moral e cívica e que deveria trabalhar junto ao Governo Federal visando melhorar as condições de vida do trabalhador brasileiro.

A multiplicação dos movimentos sindicais operários no Brasil, que se seguiu ao fim da Segunda Guerra Mundial, foi um dos motivos para a criação do SESI. Segundo Weinstein (2000, p. 161):

a onda de greves, o ressurgimento do partido comunista, francas manifestações da luta de classes e a consciência que a elite tinha de que esses fatos representavam uma profunda ameaça à paz social devem ser levados em conta para entender a criação do SESI e suas atividades nos primeiros anos de sua existência.

Quanto a isso, destaca-se que:

Com o desejo de estabelecer uma contribuição concreta para a promoção da justiça social e do bem-estar dos trabalhadores, um grupo de empresários capitaneado por Roberto Simonsen se reúne em São Paulo e lança a Carta da Paz Social como primeiro passo para humanizar as relações entre trabalho e capital, criando atividades de interesse imediato do trabalhador. O SESI seria o antídoto da crise ao criar e multiplicar armazéns pelas principais áreas industriais da capital e do interior do Estado. Em menos de um ano, já havia mais de 40 postos de abastecimento a 35 mil famílias operárias (SESI, 1949, p. 1).

A função do SENAI $^{7}$ era oferecer cursos profissionalizantes em nível de $2^{\circ}$ grau enquanto o SESI ofereceria, principalmente, cursos de alfabetização de adultos e escola para crianças e jovens (pré-primário, primário e ginásio). A esses últimos, especialmente, oferecia noções básicas para o mercado de trabalho, principalmente por meio de oficinas.

É importante destacar, nesse sentido, que na história da humanidade, como indica Enguita (1989, p. 105) “sempre existiu algum processo preparatório para a integração nas relações sociais de produção, e com frequência, alguma instituição que não a própria produção em que se efetuou esse processo".

Apesar disso, nessa relação, mesmo quando se trata dos aprendizes na Inglaterra do século XV:

Em geral, a aprendizagem e a educação tinham lugar como socialização direta de uma geração por outra, mediante a participação cotidiana das crianças em atividades da vida adulta e sem a intervenção sistemática de agentes especializados que representa hoje a escola, instituição que então [século XV] desempenhava um papel marginal (ENGUITA, 1989, p. 107).

\footnotetext{
${ }^{7}$ Cf. Carvalho, 2011
} 
Ainda segundo o mesmo autor "as salas de aula se converteram no lugar apropriado para acostumar-se às relações sociais do processo de produção capitalista, no espaço institucional adequado para preparar as crianças e os jovens para o trabalho" (ENGUITA, 1989, p. 30-31)

A crescente necessidade de mão de obra qualificada para a indústria no Brasil e as características culturais dos trabalhadores, mais acostumados com a lida no campo e, consequentemente, com outras características do trabalho, da organização do tempo e de hierarquia demandava maior capacitação para essa nova realidade.

A escola foi, então, a instituição eleita para, não apenas preparar diretamente esse novo contingente de trabalhadores, mas para, através da educação dos filhos, influenciar as famílias, incutindo novos padrões de comportamento. Entre 1900 e 1950 o número de brasileiros analfabetos com mais de 15 anos, passou de 6.370.000 para 15.350.000. Contudo, “diminuímos a percentagem de analfabetos de $65 \%$ para $51 \%$, em cinquenta anos, mas em números absolutos, passamos a ter bem mais do dobro" (Teixeira, 1994, p. 50) ${ }^{8}$.

\section{1 - A LIBERAÇÃO DA ECONOMIA}

No que diz respeito à educação, a Constituição Federal de 1946 previa a manutenção do ensino para funcionários e seus dependentes, pelas empresas com mais de cem empregados. Segundo Velloso (1987, p. 05):

aí estava sua primeira dimensão privatizante, logo no seu nascedouro: o Estado se eximia de oferecer ensino primário público e gratuito a todos, delegando parcialmente essa responsabilidade às empresas [...], as quais, caso preferissem não assumi-la, recolheriam a contribuição patronal então criada.

É preciso destacar, também, que o $\$ 1^{\circ}$, artigo $3^{\circ}$, do Decreto Lei $n^{\circ} .9 .403 / 46$, que regulamentou o Serviço Social da Indústria - SESI determinou o recolhimento de uma

\footnotetext{
${ }^{8}$ TEIXEIRA, Anísio. Educação não é privilégio. Revista Brasileira de Estudos Pedagógicos. Brasília, v.70, n.166, 1989. p.435-462 2. Ed.
} 
contribuição ${ }^{9}$ de um e meio por cento sobre o montante da remuneração paga pelos estabelecimentos industriais sobre a folha de pagamento de seus empregados ${ }^{10}$.

Essa conquista dos empresários está atrelada a ações de líderes empresariais junto ao governo. Segundo Dreifuss (1981, p. 29)

A FIESP e o CIESP formaram, também, a Comissão de Relações com o Público, destinada a modificar as demandas dos trabalhadores através de um serviço de relações públicas e doutrinação, defendendo assim os interesses da indústria privada paulista. Para tanto, em junho de 1946 o Marechal Eurico Gaspar Dutra, em resposta a pressões pessoais de Roberto Simonsen e Morvan Dias de Figueiredo, líderes da FIESP e da Confederação Nacional das Indústrias - CNI, assinou um decreto criando o Serviço Social da Indústria SESI, com o objetivo, a longo prazo, de combater o reaparecimento de organizações autônomas de trabalhadores e de construir no seio do operariado urbano uma base ideológica e de comportamento político em consonância com uma sociedade industrial capitalista".

Com o final da Segunda Guerra Mundial e as mudanças na divisão internacional do trabalho, "um bloco multinacional liderado por interesses americanos" (DREIFUSS, 1981, p. 49), penetrou na economia brasileira associando-se ao capital nacional e controlando parcialmente, por meio dele, ações de empresas estatais brasileiras, dando lugar, "a novas relações econômicas e políticas" (DREIFUSS, 1981, p. 49).

O início dos anos '50 foi marcado pela eleição de Getúlio Vargas para Presidente da República, substituindo o Marechal Dutra. “Apesar de seu compromisso com a industrialização nacionalista [...] Getúlio Vargas estendeu a mão ao governo americano e a investidores privados, numa tentativa de reconciliação e visando a um programa de desenvolvimento semelhante ao Plano Marshall" (DREIFUSS, 1981, p. 30-31).

Contudo, o governo não conseguiu cumprir suas promessas, passando a sofre pressões de sindicatos e grupos nacionalistas. Além disso, enfrentou problemas no Congresso, onde interesses setoriais articulavam para conseguir maior expressão política e poder. Segundo Dreifuss (1981, p. 33), os empresários "temiam uma forma de desenvolvimento nacionalista liderada pelo Estado", alijando os interesses multinacionais, que retornavam ao país após a Segunda Guerra Mundial, do processo de formulação de diretrizes políticas.

Os interesses multinacionais tentariam agressivamente mudar essa situação, juntamente com interesses locais que temiam a ascendência política de Getúlio

\footnotetext{
9 Esse tipo de contribuição é chamado parafiscal, pois é criada pela União e administrada pelas entidades beneficiadas.

${ }^{10}$ Até 2007 o Instituto Nacional de Seguridade Social (INSS) ficava responsável pela arrecadação e repasse dessa contribuição que, a partir da Lei $n^{\circ} 11457 / 07$, a arrecadação e repasse passaram a ser feitos pela Receita Federal do Brasil.
} 
Vargas e com forças reacionárias acuadas com as medidas sócio-democráticas com as quais Getúlio Vargas parecia ameaça-las. Acuado por outro golpe militar em 1954, Getúlio Vargas recusou-se a renunciar e suicidou-se (DREIFUSS, 1981, p. 33).

A consolidação dos sindicatos e demais associações empresariais foi acompanhada da união de interesses entre os capitais emergentes multinacionais e parte do empresariado nacional. Segundo Dreifuss (1981, p. 73),

O bloco de poder multinacional e associado incluía não somente acionistas influentes e diretores de empresas, mas também seus executivos (administradores, gerentes e técnicos) e, sua rede tecnoburocrática de influência dentro dos aparelhos do Estado.

Segundo este autor, a tecnoburocracia teve importante papel na política desenvolvimentista do presidente Juscelino Kubitschek (1956 -1961) e depois de seu governo, por meio da ocupação de cargos públicos importantes ou de empresas de consultoria. Além disso, contou com o apoio dos militares que, além de valores em comum, após a Segunda Guerra Mundial se tornaram empresários ou membros de "conselhos de diretoria das corporações multinacionais e associadas após 1964” (DREIFUSS, 1981, p. 78). Isso levou à implementação de políticas de incentivo à participação do setor privado na exploração dos recursos do país.

A proximidade entre os industriais e os militares, sua presença constante na Escola Superior de Guerra (ESG) influenciou a formação de valores empresariais entre os militares. Segundo Dreiffus (1981, p. 79), "Ideologias americanas de 'construção nacional' foram disseminadas entre as Forças Armadas Brasileiras e reforçadas pela doutrina empresarial".

A ascensão de Joao Goulart ao poder (1961-1964) e sua política nacional - reformista, trouxe à tona a aliança da burguesia industrial nacional e associada com setores das Forças Armadas através do ataque ao populismo personificado na figura no presidente. Essa campanha de desestabilização levou à desagregação do bloco de poder e estabelecimento de um novo bloco associado aos interesses multinacionais.

A vanguarda da poderosa coalizão burguesa antipopulista e antipopular, localizada nos vários escritórios de consultoria, anéis burocráticoempresariais, associações de classe dominantes e militares ideologicamente congruentes, beneficiando-se do apoio logístico das forças transnacionais, transformou-se num centro estratégico de ação política, o complexo IPES/IBAD. (DREIFUSS, 1989, p. 143).

A ação do complexo IPES (Instituto de Pesquisas e Estudos Sociais) / IBAD (Instituto Brasileiro de Ação Democrática) foi profundamente analisada por Dreifuss (1981). Este autor, entre outros aspectos, apresenta ações da burguesia industrial e associada e de setores das Forças Armadas para desestabilizar política e economicamente o país, viabilizando a realização do 
Golpe de 1964 e a maior abertura do país para os capitais multinacionais, o que foi fundamental para o desenvolvimento do SESI.

Com destaca Cunha (2002, p. 41),

Vitorioso o golpe de 1964, subiram ao poder defensores do privatismo na educação, aqueles que defendiam a desmontagem ou, pelo menos, a desaceleração do crescimento da rede pública de ensino. Em compensação, as verbas públicas destinadas ao ensino deveriam ser transferidas às escolas particulares que, então, se encarregariam da escolarização das crianças e dos jovens. Só onde a iniciativa privada não tivesse interesse em abrir escolas é que a escola pública seria bem-vinda.

Ainda, conforme o mesmo autor, em 1965, a revisão do Plano Nacional de Educação, entre outras medidas, "aumentou os recursos a serem transferidos para o setor privado" (CUNHA, 2002).

Em 1964, por exemplo, a criação do salário educação e o crescimento do setor industrial proporcionaram aumento nas receitas da entidade, favorecendo essa expansão.

Para Cunha (2002, p. 42), esse é "um exemplo dramático de como uma boa ideia pode ser distorcida pela corrupção institucionalizada pela ditadura”. Isso porque, outros países do mundo "já adotavam formas de participação das empresas no financiamento do ensino proporcional ao montante dos investimentos das empresas ou dos salários pagos por elas aos seus empregados" (CUNHA,2002, p. 42). 


\section{2 - REPENSANDO O ENSINO}

A criação do SESI e de outras entidades ligadas ao Sistema $S$, é um importante sinal da influência política do capital privado junto às esperas de poder federal e de que o tecnismo na educação nacional tem ganhado força a mais de setenta anos.

[...] esta Teoria [tecnicista] de Educação começou a ganhar força ainda na década de 1940, em decorrência do processo de industrialização do país. Um dos exemplos é a criação, a partir de 1946, do Sistema S, compreendido pelo SENAI, SESI, SENAC, SESC E SENAC, que seria responsável pela qualificação dos trabalhadores da indústria, do comércio, da agricultura e da assistência social dos mesmos. Segundo Saviani (1996), é com o Regime Militar que o Tecnicismo será consolidado como política pública para a área da educação (MENGER e VALENÇA 2012, p. 502).

Exemplo disso é que na década de 70, como o objetivo era a preparação do aluno para o trabalho, foram inseridas na Parte Diversificada do currículo da Rede SESI-SP as disciplinas de "Área Econômica Secundária", seguindo as características da comunidade onde as escolas estavam inseridas. O currículo era composto de disciplinas diferenciadas, conforme a necessidade da unidade:

$1^{\circ}$ - Área econômica primária: agricultura, criação de animais;

$2^{\circ}$ - Área econômica secundária: metalurgia, madeira, artes gráficas, cerâmica, couro, plástico, têxtil, eletricidade, fotografia;

$3^{\circ}$ - Área econômica terciária: comércio, administração, contabilidade, bancos e valores (GUMIERO, 2002, p. 83).

Entretanto,

com o fim da Ditadura Militar, houve a constatação formal, por parte do Estado e, inclusive, de setores empresariais, de que a questão social tem uma dimensão institucional como "dívida social" a ser resgatada para que o país alcance o projeto de modernidade. Antes disso, a pobreza não era considerada "problema" da sociedade e, portanto, público, ou um fenômeno disfuncional do sistema social. Assim, não eram previstas políticas para seu enfrentamento (OLIVEIRA e FERREIRA, 2008, p. 29).

Na década de 1960, o aumento da demanda por vagas e por mão de obra mais qualificada para o trabalho na indústria leva o SESI-SP a organizar uma equipe central para desenvolver ações e orientações pedagógicas para sua rede, assim como acompanhar os processos pedagógicos e administrativos das escolas. Apesar disso, por questões locais e tecnológicas, essa efetivação ganhou força apenas no final da década de 1990, como se verá a seguir. 
A constituição de 1988 ratificou a legitimidade da oferta de serviços educacionais por instituições privadas e fixou as bases para a elaboração de uma nova Lei de Diretrizes e Bases da Educação Nacional (LDB), promulgada em 1996 (Lei no 9.394) a qual, por sua vez, levou à elaboração dos Parâmetros Curriculares Nacionais. Essa lei instituiu

um projeto do Senador Darcy Ribeiro, apresentado como substitutivo ao projeto já aprovado na Câmara dos Deputados e amplamente discutido com a sociedade organizada brasileira. Assim, foi aprovada uma proposta de LDB que incluía as diretrizes do Banco Mundial para a educação dos países em desenvolvimento, em detrimento de um projeto de lei que contava com a colaboração e o apoio da sociedade organizada [...]. (OLIVEIRA, 2001, p. 157).

Em consonância com a nova LDB, após um trabalho que envolveu os docentes e a equipe central do SESI-SP, que levou à mudanças no Regimento Comum que reforçava o caráter contínuo da aprendizagem e a progressão continuada, em 1999 o SESI organizou o Ensino Fundamental em quatro ciclos: Ciclo I ( $1^{\circ}$ e $2^{\circ}$ anos), Ciclo II ( $3^{\circ}$ e $4^{\circ}$ anos), Ciclo III $\left(5^{\circ}\right.$ e $6^{\circ}$ anos) e ciclo IV ( $7^{\circ}$ e $8^{\circ}$ anos). Essas mudanças impactaram na forma de avaliação dos estudantes, com a substituição das notas (0-10) por menções (PS - Progressão Satisfatória e PI - Progressão Insatisfatória).

Com isso, as escolas que, apesar de seguirem diretrizes gerais, pela distância entre si e de sua Sede, assumiam características locais, passaram a se organizar de forma mais coesa, dando passos importantes para constituir uma rede onde a proposta pedagógica pudesse ser reconhecida em cada uma das unidades, conforme orientações de sua Sede, localizada na Avenida Paulista, em São Paulo - SP.

Para concretizar essas mudanças, foi necessário reestruturar a Diretoria de Educação Básica do SESI-SP e, em 2001, a equipe central foi ampliada com a contratação de novos especialistas (Analistas Técnico-Educacionais) e supervisores. Aquele ano também foi dedicado à formação dessa nova equipe que, em parceria firmada com a PUC-SP participou de um curso de especialização. Essa equipe, ainda, com ajuda de consultores externos ligados à Universidade Estadual Paulista (UNESP) iniciou a elaboração do Referencial Curricular da Rede SESI-SP e ficou responsável em levar as discussões sobre o documento às bases. Essa decisão foi a mais significativa, desde a formação da equipe central, com vistas a criar uma identidade para as escolas da rede SESI-SP.

A partir de então, foi implementado um programa de formação continuada de professores, também com a participação dos especialistas e coordenadores pedagógicos, que consistia em quatro encontros anuais de quatro horas, em diferentes polos na capital e no 
interior. Nesses encontros os professores se reuniam com seus pares do mesmo componente curricular e com Analistas Pedagógicos para estudar, partilhar experiências, discutir a proposta pedagógica da rede e vivenciar atividades tendo em vista a implementação da proposta curricular em discussão. Em 2003, como resultado dessas discussões, foi publicado o "Referencial Curricular da Rede SESI-SP”, intensificando-se os esforços no processo de formação dos professores para que a proposta pedagógica fosse efetivamente colocada em prática.

A leitura desse referencial nos remete a uma educação liberal, que visa a emancipação do indivíduo. Em consonância com as discussões sobre o papel da escola no final do século XX, o Referencial Curricular da Rede SESI-SP enfatiza a importância do desenvolvimento de habilidades e competências, a valorização dos conhecimentos dos estudantes enquanto um procedimento metodológico de ensino, a avaliação durante o processo de ensino e aprendizagem e o trabalho com leitura e escrita em todos os anos e componentes curriculares.

À época, a compreensão que se teve dos referenciais teóricos que embasaram a proposta curricular da Rede, de certa forma, relegou os conteúdos conceituais ${ }^{11}$ ao segundo plano do processo de ensino e aprendizagem. Isso porque, enfatizou-se o que o estudante precisaria aprender a fazer (identificar, analisar, localizar, relacionar etc.) mesmo, apesar da dimensão conceitual dos conteúdos ser reconhecida com importante. Dessa forma o conhecimento científico é relegado a um segundo plano.

Na obra "Vigotski e o 'aprender a aprender': crítica às apropriações neoliberais e pósmodernas da teoria vigotskiana", Nilson Duarte (2000) defende que as pedagogias do "aprender a aprender" às quais integra a pedagogia das competências retiram da escola a responsabilidade em transmitir o conhecimento social objetivo. Desta forma, "aprender sozinho contribuiria para o aumento da autonomia do indivíduo, enquanto aprender como resultado de um processo de transmissão por outra pessoa seria algo que não produziria a autonomia e, ao contrário, muitas vezes até seria um obstáculo para a mesma” (DUARTE, 2001, p. 36).

Partindo do pressuposto que se deveria priorizar o desenvolvimento de habilidade e competências, que os estudantes deveriam aprender a aprender, as expectativas de ensino e aprendizagem apresentadas na primeira versão do Referencial Curricular que norteariam o trabalho dos professores foram escritas de tal forma que os conteúdos conceituais não

\footnotetext{
${ }^{11}$ Os conteúdos conceituais dizem respeito ao conhecimento construído ao longo da história, pela humanidade.
} 
estivessem claramente explícitos, cabendo, aos professores, identificá-los. Com isso, se institucionalizou um currículo que, de certa forma, desvaloriza o conhecimento historicamente e socialmente produzido e acumulado. Essa escolha dificultou a ação dos docentes. Quanto a isso é importante salientar que, naquele momento, parte dos professores, nas diferentes regiões do estado, apesar de serem habilitados, não tinha formação específica no componente curricular. Mesmo quando os professores tinham a formação específica, estavam habituados a pensar em quais conteúdos ensinar aos estudantes com os quais trabalhavam, não em como fazê-lo ou em como as estratégias utilizadas poderiam impactar na aprendizagem dos estudantes. Essa dificuldade levou a uma primeira reformulação das expectativas de ensino e aprendizagem, em 2009/2010, quando a organização do Ensino Fundamental passou a ser em anos e, a outra, quando o Referencial Curricular foi atualizado, em 2014/2015.

Por outro lado, sem desconsiderar a importância da continuidade dos estudos, é preciso atenção a esse discurso que enfatiza, principalmente, as dificuldades dos professores e sua formação deficiente. Isso porque, segundo Ferreira (2006), nele está implícita a falta de compromisso com a formação inicial de professores. Dessa forma se estabelece um mercado privado de formação continuada de professores que se estrutura e se sustenta com recursos que deveriam ser destinados à educação pública.

Nos dois momentos de reelaboração das expectativas de ensino e aprendizagem, acima citados, buscou-se atender certas demandas dos professores que solicitavam que o texto das expectativas de ensino e aprendizagem fosse mais claro, com os conteúdos mais explícitos, como mostrado a seguir:

Exemplos de expectativas de ensino e aprendizagem de Geografia $-6^{\circ}$ ano

\begin{tabular}{|c|c|c|}
\hline $2003 *$ & $2009 * *$ & $2014 * * *$ \\
\hline $\begin{array}{l}\text { Reconhecer as dinâmicas } \\
\text { internas e externas de } \\
\text { construção do planeta, para } \\
\text { compreender as suas } \\
\text { diferentes características }\end{array}$ & $\begin{array}{lr}\text { Reconhecer } & \text { as } \\
\text { dinâmicas internas e } & \text { externas de construção } \\
\text { do planeta, para } \\
\text { compreender suas }\end{array}$ & $\begin{array}{l}\text { Reconhecer as diferentes formas da } \\
\text { superfície terrestre, relacionando-as } \\
\text { com seus processos de formação e } \\
\text { transformação (agentes internos e } \\
\text { externos). }\end{array}$ \\
\hline $\begin{array}{l}\text { tempo da natureza, do tempo } \\
\text { da sociedade (o vulcanismo, } \\
\text { o movimento das placas } \\
\text { tectônicas, os agentes } \\
\text { erosivos e a ação humana). }\end{array}$ & $\begin{array}{l}\text { características físicas, } \\
\text { diferenciando o tempo } \\
\text { da natureza do tempo } \\
\text { da sociedade. }\end{array}$ & $\begin{array}{l}\text { Comparar o tempo da natureza e da } \\
\text { sociedade nos diferentes processos } \\
\text { relacionados à formação e à } \\
\text { transformação } \\
\text { terrestre. }\end{array}$ \\
\hline
\end{tabular}


Apesar do processo de reformulação, manteve-se o princípio do trabalho com habilidades e competências expresso no Referencial Curricular de 2003 e sua concepção de educação.

a concepção de educação que permeia o presente referencial curricular é aquela que engloba ensino, aprendizagem e pesquisa. A finalidade do processo ensino e aprendizagem é o conhecimento da realidade, tendo como meta transformá-la, visando a construção de um mundo no qual todos possam realizar a sua humanidade (SESI-SP, 2003, p. 20).

Visando complementar o trabalho realizado na formação continuada de professores e a consolidação de seu Referencial Curricular, entre 2009 e 2013, o SESI-SP inicia os trabalhos para a elaboração de seu próprio material didático e, dessa forma, compensar a "ausência" dos conteúdos nas expectativas de ensino e aprendizagem. Inicialmente foi elaborado o do Ensino Fundamental (em fase de revisão) e, em seguida, do Ensino Médio.

A seguir, exemplos de objetivos extraídos de duas pautas de encontros realizados em 2008 (ANEXOS 1 e 2).

\begin{tabular}{|c|c|}
\hline \multicolumn{2}{|c|}{$\begin{array}{l}\text { Objetivos de Encontros de Formação de Professores de Geografia } \\
\qquad \text { Rede Escolar SESI-SP - } 2008\end{array}$} \\
\hline Ensino Fundamental & Ensino Médio \\
\hline $\begin{array}{l}\text { Discutir o trabalho com as } \\
\text { expectativas de ensino e } \\
\text { aprendizagem dos ciclos III e IV } \\
\text { que possibilitem desenvolver } \\
\text { atividades relacionadas aos Jogos } \\
\text { Olímpicos. }\end{array}$ & $\begin{array}{l}\text { Proporcionar momentos de vivência e reflexão sobre a prática } \\
\text { docente; } \\
\text { Refletir sobre as expectativas de ensino e aprendizagem } \\
\text { considerando o currículo para o primeiro e o segundo ano do } \\
\text { EM da rede SESI de ensino; }\end{array}$ \\
\hline $\begin{array}{l}\text { Promover momentos de discussão } \\
\text { e elaboração de atividades. }\end{array}$ & $\begin{array}{l}\text { Oportunizar reflexões acerca da importância } \\
\text { operacionalização da avaliação em sua dimensão formativa. }\end{array}$ \\
\hline
\end{tabular}

Quadro 2 - Objetivos: Encontro de Formação de professores EF II e EM (Fonte: Arquivo pessoal do autor)

Assim, a primeira edição do livro didático da rede priorizou a apresentação de atividades que norteassem o trabalho do professor, ficando, este, responsável pela escolha dos conteúdos visando atingir as expectativas de ensino e aprendizagem para cada unidade didática, como pode ser percebido na imagem a seguir: 


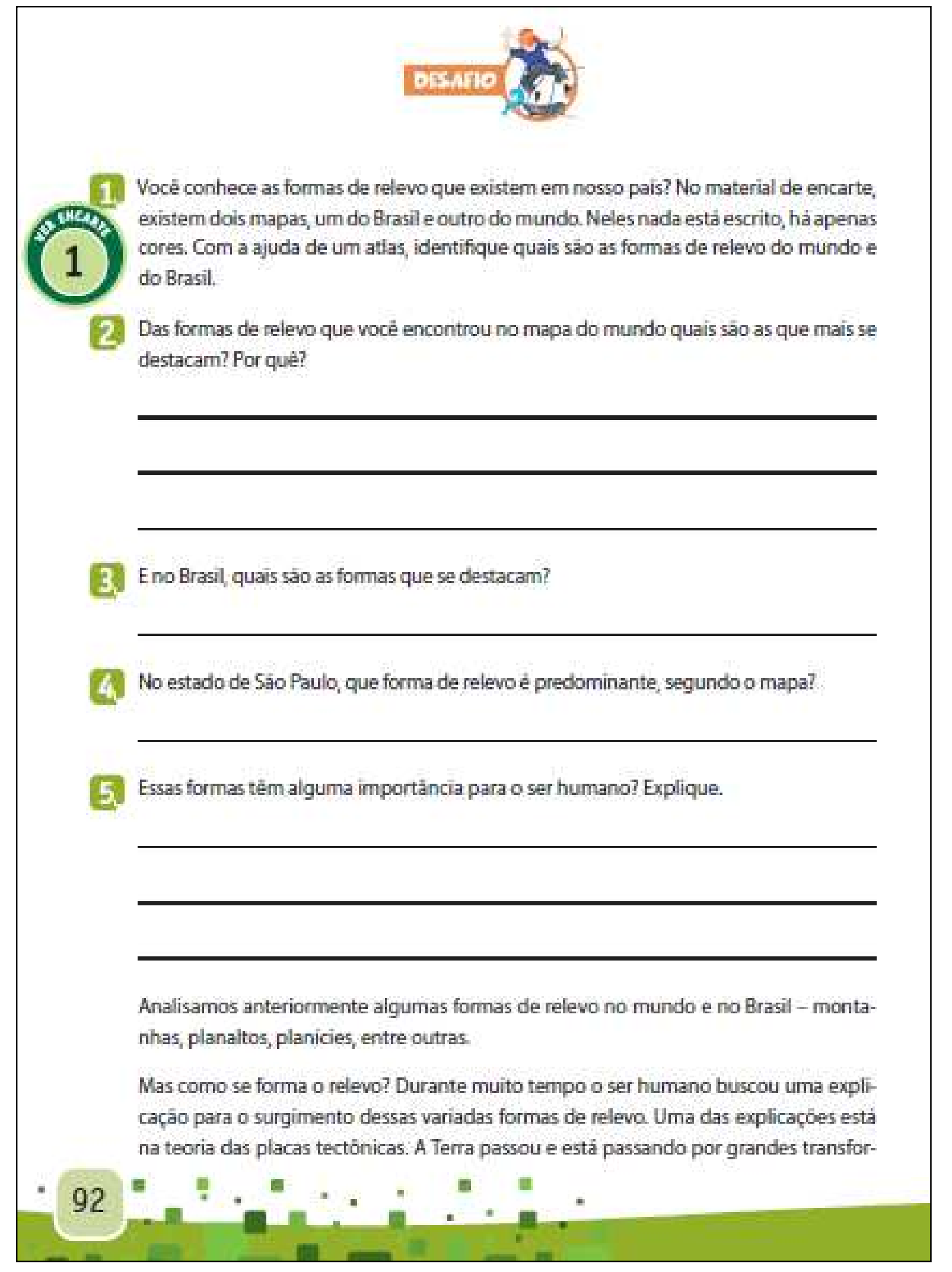

Figura 5 - Página do livro Movimento do Aprender $6^{\circ}$ ano - Geografia 
Nessa proposta,

[...] textos isolados uns dos outros, fragmentos literários, notícias de jornal, partes de poesia, frases soltas, substituíram, nos currículos escolares, o ensino que buscava conhecer as necessidades e possibilidades dos homens no interior de sua civilização ou que buscava conhecer o desenvolvimento histórico, cultural da sociedade (NAGEL, 2003, p. 37).

Essa proposta recebeu muitas críticas de professores do SESI-SP e, também, das prefeituras conveniadas $^{12}$ ao Sistema SESI-SP de Ensino. O relatório sobre a percepção dos professores de Geografia da Rede Escolar SESI-SP, sobre o material didático destaca que:

[...] 59\% das respostas indicaram problemas diversos, como a dificuldade de interpretação por parte dos alunos, atividades repetitivas e falta de articulação entre o "Movimento do Aprender" e o "Muitos Textos... Tantas Palavras". Observa-se, também, que parte significativa das respostas (23\%) indicam conflitos entre a percepção do professor e a proposta do material (ou demonstra pouco conhecimento dela) na medida em que se queixam do "nível elevado dos textos" relacionando-os a "imaturidade dos estudantes" e aos espaços disponíveis na escola para realização das atividades. (SILVA, JR, 2013, p. 9)

Como consequência dessas críticas e da avaliação da equipe central que entendeu que o material poderia ser melhorado, sem ferir à concepção ensino e, ainda assim, contribuir para a melhor aprendizagem dos estudantes, o material didático do Ensino Médio, em sua primeira versão, já apresentou características diferenciadas, com mais textos, questões de vestibulares e relação entre os conteúdos apresentados e o mundo do trabalho. Isso, também, em função das características dessa etapa da escolarização na qual, se espera que os estudantes tenham maior autonomia para estudar considerando as orientações dos professores e os conteúdos apresentados nos livros.

A experiência do trabalho de desenvolvimento dos livros do Ensino Fundamental II também foi importante para os avanços na produção dos livros do Ensino Médio. Em Geografia, por exemplo, as unidades foram definidas previamente, assim como as expectativas de ensino e aprendizagem a serem trabalhadas em cada uma delas. A partir disso, os técnicos do SESI-SP elaboraram roteiros de cada unidade para somente depois enviarem à editora que, à época, foi a Editora Módulo, de Curitiba-PR, contratada por ter vencido a licitação para produção do material.

Por pressão dos técnicos da Divisão de Educação do SESI-SP, os autores contratados pela Editora Módulo, para elaboração do material do didático do Ensino Fundamental foram

\footnotetext{
${ }^{12}$ Prefeituras assinam contrato para implantação do Sistema SESI-SP em suas escolas, a que se refere o Capítulo 3 , desse trabalho.
} 
substituídos. Também foi mudada a relação entre estes e os técnicos que puderam manter contato direto, sem intermediação de supervisores ou gerentes do SESI-SP, estabelecendo um processo colaborativo de produção do material do Ensino Médio. Com isso, foi possível produzir um livro melhor estruturado em relação aos conteúdos apresentados, de forma que seu desencadeamento não dependesse da aula expositiva ou dos registros dos professores, como na figura a seguir:
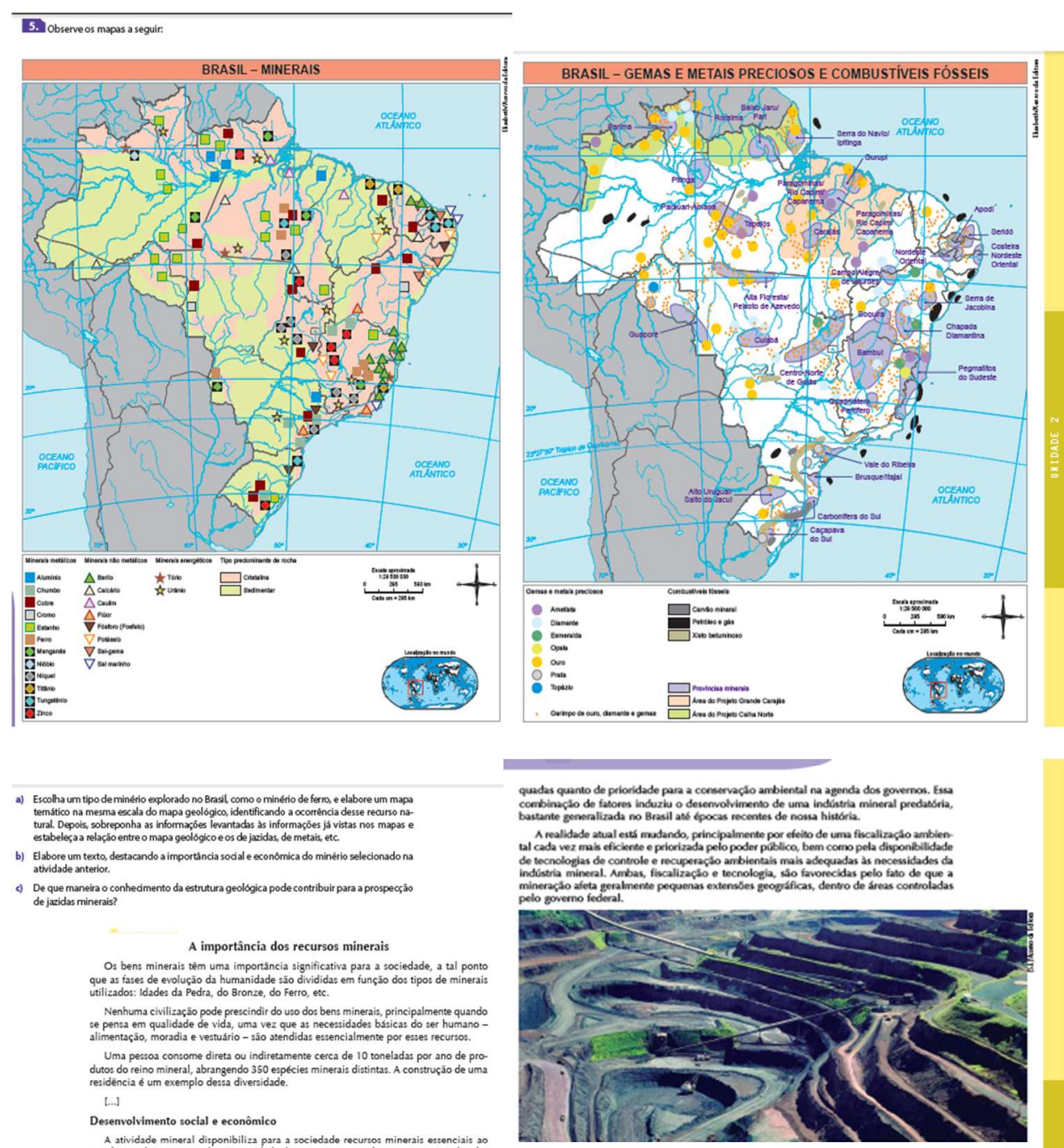

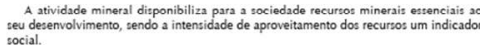

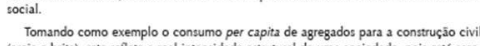

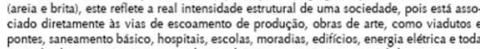

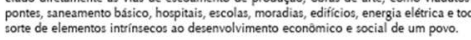

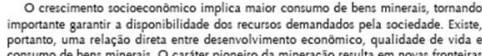

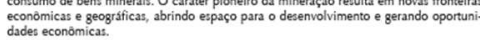

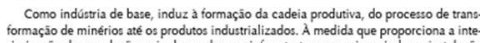

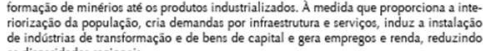

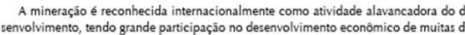

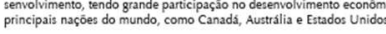
Meio ambiente

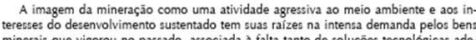

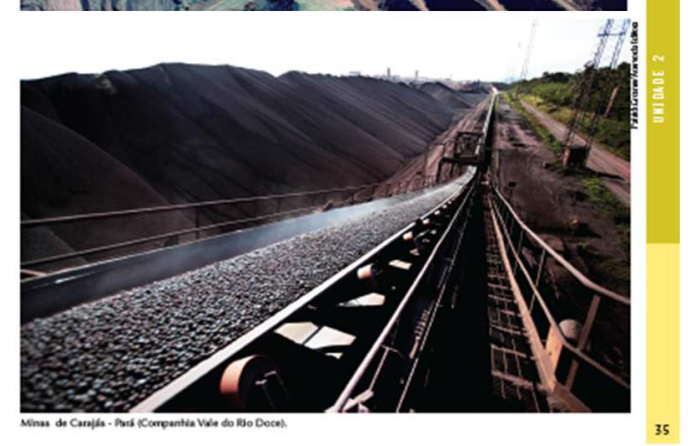

Figura 6 - Páginas do livro Movimento do Aprender - Geografia - $1^{\circ}$ ano do EM 
A partir de 2011, com o aumento de demandas como a elaboração do material didático do Ensino Médio e a formação dos professores das prefeituras conveniadas ao recém-criado Sistema SESI-SP de Ensino, o modelo de formação continuada dos professores do SESI-SP foi substituído gradualmente, passando a ser realizado parcialmente à distância, acompanhado da mudança de regime de trabalho de parte dos professores, conhecido como $36+4$ (trinta e seis horas/aula + quatro horas de trabalho e estudo coletivo).

Essas mudanças na formação dos professores contribuem para o processo de centralização da tomada de decisões, constituem elementos significativos rumo a implementação de um currículo cada vez mais prescritivo e fortalecem a figura do Coordenador Pedagógico, indicando uma visão de que, a superação dos problemas de aprendizagem (ou baixo desempenho em avaliações externas) passa primeiro pela gestão da escola.

Apesar do encerramento da formação dos professores pela estrutura interna institucional do SESI-SP e das críticas ao material didático, ainda assim, alcançou-se resultados positivos no que diz respeito à aprendizagem de Geografia que podem ser percebidos nos dados das avaliações em larga escala, como SARESP (Figura 7), em comparação à rede pública estadual e redes privadas (ao menos em relação aos conteúdos e parâmetros utilizados nessa avaliação). Contudo, será necessário um olhar mais específico sobre essa questão, uma vez que o histórico dos dados não possibilita identificar uma tendência clara de melhora nos resultados e, portanto, dos impactos do material didático e das mudanças na formação continuada dos professores na aprendizagem dos estudantes.

Os resultados, expressam a necessidade de olhar mais objetivamente para a realidade do ensino que se realiza nas escolas, embora a média de proficiência em Geografia de todos os anos avaliados esteja no nível adequado. Ao analisar esses dados, entretanto, é preciso ter o cuidado de não enveredar pela dicotomia escola pública, ruim X escola privada boa. Como indicam Silva e Gentili (1994, p. 126) isso desviaria a discussão para a ideia de qualidade presente no meio empresarial, minimizando ou desconsiderando a necessidade de democratização da educação. 


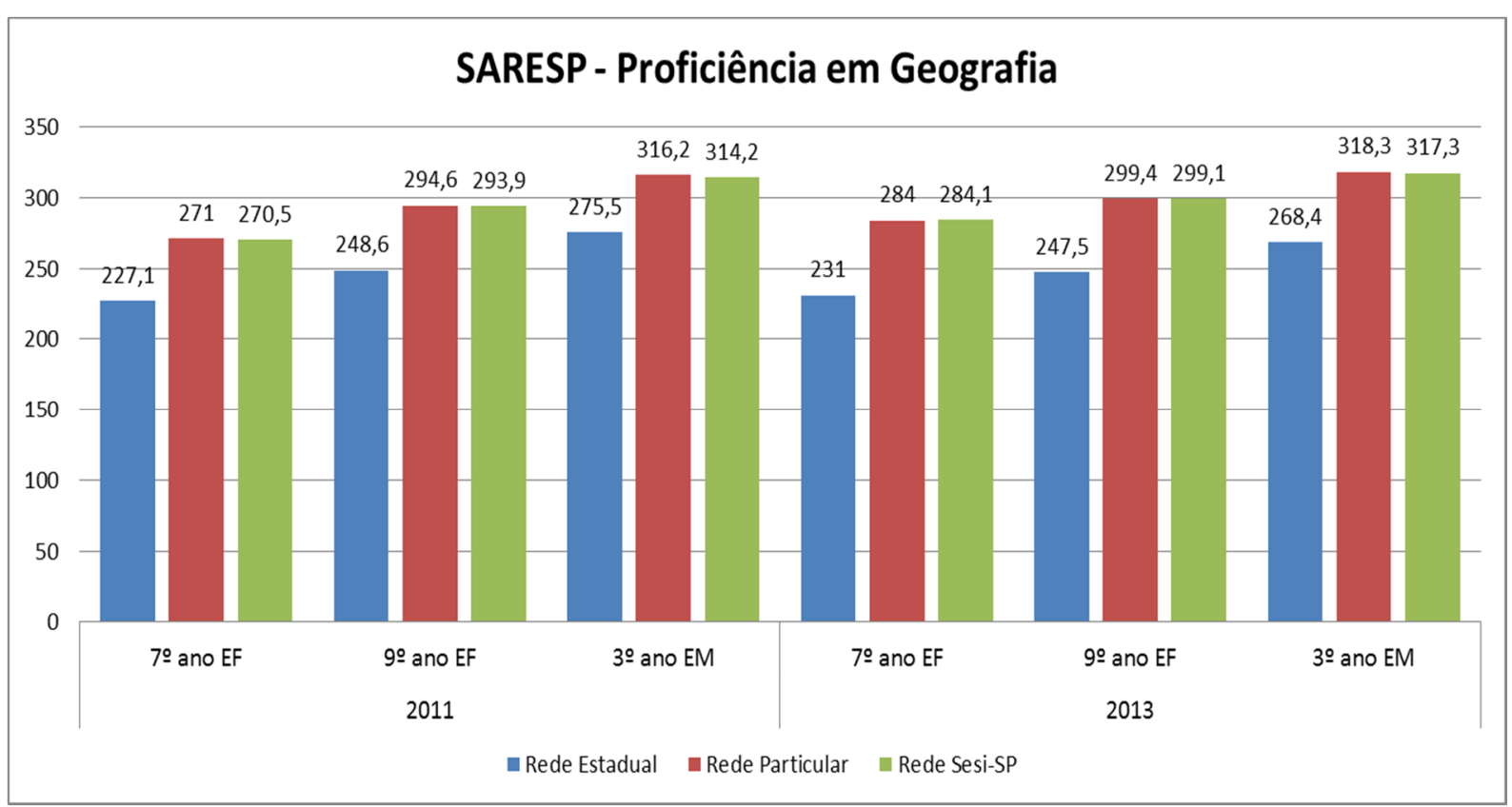

Figura 7 - SARESP - Proficiência ${ }^{13}$ em Geografia (Fonte: SESI. SARESP - Relatório Geral da Rede SESI)

Embora os resultados das escolas da Rede SESI-SP sejam consideravelmente melhores

que os da Rede Pública Estadual de Ensino e, equiparados aos resultados da Rede Particular ${ }^{14}$, isso não quer dizer que os resultados sejam satisfatórios. Ressalta-se também, que em todas as séries avaliadas, o SESI-SP está ainda distante do nível de proficiência "avançado", o que demonstra mais uma vez, a necessidade de aprimoramento do trabalho educativo ofertado.

Tomando as figuras 8 e 9 como exemplo, percebe-se que, de modo geral ainda há um longo caminho a percorrer para se chegar ao nível avançado e para a redução do número de estudantes nos níveis, básico e abaixo do básico.

Mas, além das avaliações em larga escala, como o SARESP, é preciso considerar também outros indicadores para efetivamente verificar, em cada escola e, no âmbito da rede (ou de escolas) o nível de aprendizagem dos estudantes nos diferentes componentes curriculares. Embora as avaliações externas busquem verificar as habilidades e competências já desenvolvidas pelos alunos, assim como os conhecimentos gerais relacionados às especificidades das disciplinas avaliadas, é preciso considerar que ela representa apenas um

\begin{tabular}{l}
\hline \multicolumn{1}{|c|}{$\mathbf{7}^{\mathbf{0}}$ ano EF } \\
\hline
\end{tabular}

${ }^{14}$ Em 2011, das 216 escolas particulares que participaram do SARESP, 177 eram do SESI-SP. Em 2013, essa relação foi de 174 escolas do SESI-SP no total de 194 escolas particulares participantes. 
recorte da realidade, e há variáveis que podem e certamente interferem, no resultado dos alunos, tais como: o significado que essas avaliações têm para eles, o comprometimento com que resolvem as questões, a familiaridade com o estilo das questões, o tempo de duração da prova, normalmente mais extenso do que o que estão habituados nas avaliações internas realizadas na escola, , entre outros.

Nos itens de avaliação propostos, há grande ênfase na avaliação das competências leitora e interpretativa dos estudantes e também nos conteúdos do currículo, porém, é preciso considerar que avaliam em parte, o desenvolvimento dos conhecimentos dos estudantes, uma vez que não é possível verificar, em uma única prova, todas as habilidades, competências e conteúdos previstos no currículo e apreendidos pelo aluno. Porém, mais que os resultados das avaliações externas, é preciso também, uma análise do seu desempenho nas avaliações internas, e principalmente, o acompanhamento e registros do seu desenvolvimento durante o seu percurso, o que trará dados mais precisos e fidedignos à realidade.

Para uma análise mais aprofundada, seria preciso um maior estudo também, da escala de proficiência que é base do SARESP. Será que os níveis estabelecidos se referem realmente a um nível de ensino e aprendizagem adequados ao que é desejável para uma boa formação, ou serão eles estabelecidos de forma a já nivelar por baixo, a aprendizagem dos estudantes?

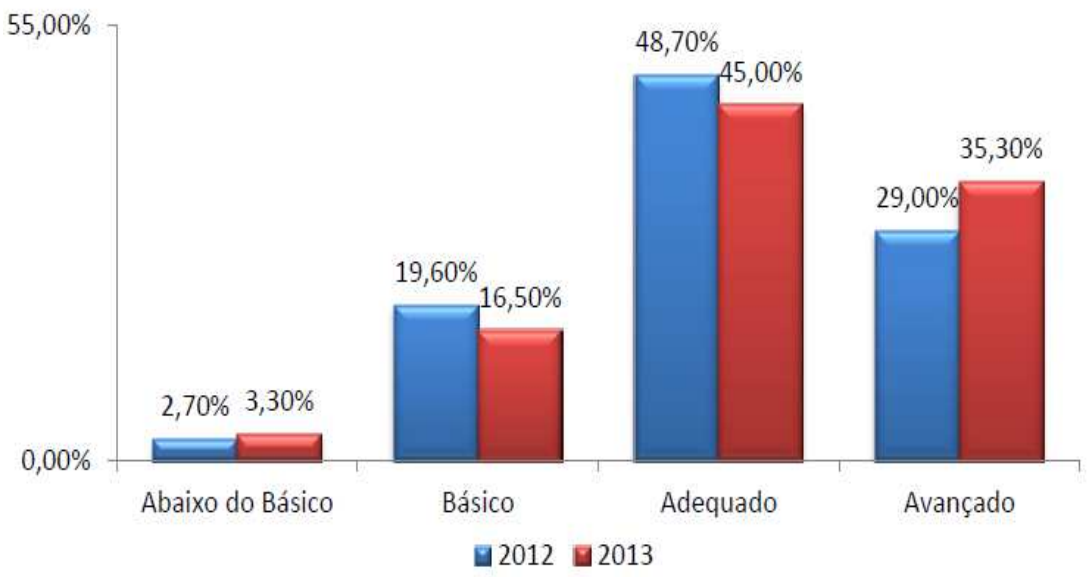

Figura 8 - Comparativo 2012 e 2013, da distribuição percentual dos estudantes em relação aos níveis de proficiências em Língua Portuguesa ${ }^{15}$ no $7^{\circ}$ ano. (Fonte: SARESP: Relatório Geral da Rede SESI)

\footnotetext{
${ }^{15} \mathrm{O}$ relatório não apresenta classificação dos níveis de proficiência em Geografia.
} 


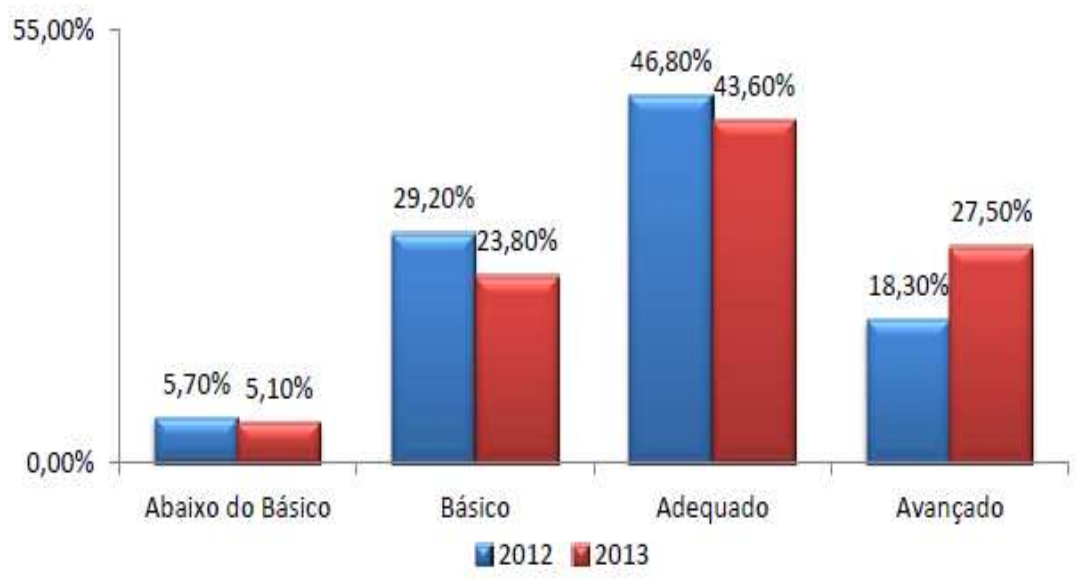

Figura 9 - Comparativo 2012 e 2013, da distribuição percentual dos alunos em relação aos níveis de proficiências em Matemática no $7^{\circ}$ ano. (Fonte: SARESP: Relatório Geral da Rede SESI)

O fato dos relatórios internos do SESI-SP não analisarem com maior profundidade o desempenho dos estudantes em Ciências Humanas (História e Geografia), ao contrário do que faz com Língua Portuguesa e Matemática, revela a valorização de determinadas áreas do conhecimento em detrimento de outras. O mesmo acontecendo na esfera estadual, uma vez que o desempenho em Geografia e História é avaliado bianualmente. 


\subsection{A REESTRUTURAÇÃO DA DIVISÃO DE EDUCAÇÃO: PREPARANDO O CAMINHO PARA A PRESTAÇÃO DE NOVOS SERVIÇOS}

Com a entrada em vigor da lei n ${ }^{\circ} 11.274 / 06$, instituindo o Ensino Fundamental de nove anos, o SESI-SP implanta em 2007, de forma gradual, o seu Programa de Educação Integral em Tempo Integral e passa a oferecer Ensino Médio. Este por sua vez, articulado com a educação profissional do SENAI-SP. A Resolução 02/06 que implanta essas mudanças, também institui a cobrança de taxa escolar para os estudantes da Educação Infantil e do Ensino Fundamental e de mensalidade para os matriculados no Ensino Médio (ANEXO 3).

É preciso considerar que no cerne da instituição da escola em tempo integral, em âmbito nacional, tem-se a discussão sobre a garantia de maior tempo para aprendizagem, mas, também, sobre sua adoção como medida compensatório às deficiências da Escola Básica e como possiblidade manter as crianças e jovens mais tempo longe das ruas o que, como destaca Saviani (1987), acaba convergindo em políticas "pobres para os pobres" sem maiores preocupações com a qualidade da aprendizagem e com as condições para aprender .

Praticamente no mesmo período, em 2008, com o intuito de ampliar a oferta de cursos de formação profissional gratuitos, em especial dos cursos técnicos de Ensino Médio a estudantes de escolas públicas e trabalhadores desempregados, o Governo Federal começa a discutir modificações na distribuição dos recursos ao Sistema S, mudanças essas que afetam também o SESI-SP.

Essa alteração na distribuição dos recursos consistia em destinar $1,5 \%$ dos recursos arrecadados sobre a folha de pagamentos à educação e 1,0\% às atividades sociais (o inverso do que é praticado hoje). Ainda segundo essa proposta, os recursos continuariam sendo administrados pelos gestores atuais.

Entretanto, devido a pressões do setor empresarial, com apoio do então vice-presidente da República, José de Alencar, a proposta não foi levada a cabo, sendo substituída pelo decreto 6637 de 05 de novembro de 2008 acrescendo ao Regulamento do Serviço Social da Indústria, o que segue:

Art. 2o O Regulamento do Serviço Social da Indústria - SESI, aprovado pelo Decreto $\mathrm{n}^{\mathrm{0}} \mathbf{5 7 . 3 7 5}$, de 1965, passa a vigorar acrescido dos seguintes artigos: 
"Art. 69. O SESI vinculará no seu orçamento geral, anual e progressivamente, até o ano de 2014, o valor correspondente a um terço da receita líquida da contribuição compulsória, correspondente a vinte e sete inteiros e setenta e cinco centésimos por cento da receita bruta da contribuição compulsória, às ações mencionadas no $\S 2^{\circ}$ do art. $6^{\circ}$, sendo que a metade deste valor, equivalente a um sexto da receita líquida da contribuição compulsória, deverá ser destinada à gratuidade.

$\S 1^{\mathrm{o}}$ A alocação de recursos vinculados à educação e à gratuidade, de que trata este artigo, deverá evoluir, anualmente, a partir do patamar atualmente praticado, de acordo com as seguintes projeções médias nacionais:

I - para a educação:

a) vinte e oito por cento em $2009 ;[\ldots]$

e) trinta e dois por cento em 2013; e

f) trinta e três inteiros e trinta e três centésimos por cento a partir de 2014; e

II - para a gratuidade:

a) seis por cento em 2009; [...]

e) catorze por cento em 2013; e

f) dezesseis inteiros e sessenta e sete centésimos por cento a partir de 2014.

Apesar dessas mudanças, pode-se dizer que os interesses do empresariado foram preservados, garantindo a gestão desses recursos pela iniciativa privada. A Educação se consolida como um negócio e é possível considerar que, se fortalece a perspectiva de formação de mão de obra qualificada, preparada para competir no mercado cada vez mais competitivo e globalizado, em sintonia com o pensamento liberal, mas, também para aceitar esse pensamento favorável ao livre mercado e à livre iniciativa. Ou seja, em sintonia com os princípios e a mesma estrutura conservadora sobre a qual se edificou o projeto de Educação Nacional, no século passado.

Embora se refira à Educação Superior, a consideração de Oliveira (2000) também pode ser articulada à atual realidade da Educação básica:

No início desta década [anos 2000], ao se identificar que o setor de educação superior sofreria rápida expansão, a atenção dos fundos de investimento voltou-se para essa área [...]. Esses fundos têm condições de injetar altas quantias em empresas educacionais, ao mesmo tempo em que empreendem ou induzem processos de reestruturação das escolas nas quais investem, por meio da redução dos custos, da racionalização administrativa, em suma, da "profissionalização" da gestão das instituições de ensino, numa perspectiva claramente empresarial (OLIVEIRA, 2009, p. 743).

Nesse contexto (da Educação Básica), além dos Sistemas de Ensino Privados, que vendem serviços às redes públicas municipais e estaduais, o Programa Nacional do Livro Didático (PNLD), criado em 1985, com o Decreto nº 91.542/85 (BRASIL, 1985), também se 
tornou uma forma de financiamento do setor privado com recursos públicos e contribuiu para a concentração do mercado editorial nesse setor.

Um sinal dessa constatação é a quase extinção dos Centros de Educação Infantil mantidos pelo SESI-SP e maiores investimentos no aumento de vagas no Ensino Médio e Ensino Técnico, assim como no Ensino Médio articulado aos cursos técnicos do SENAI.

É importante notar que, mesmo com ensino pago, 28\% dos estudantes da Educação Básica nas escolas da rede SESI é isenta de pagamento ${ }^{16}$, em função de serem filhos de funcionários ou da renda familiar per capita não ultrapassar R \$ 622,00.

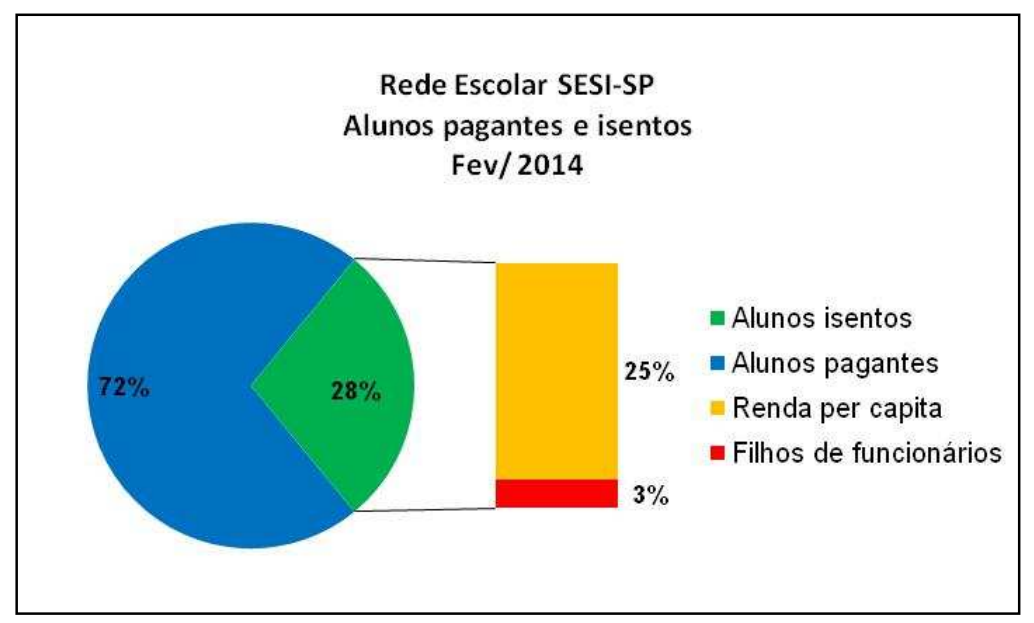

Figura 10 - Rede Escolar SESI-SP: Alunos pagantes e isentos - Fev/ 2014 (Fonte: SISGER/SESI-SP)

Com a decisão de instituir a cobrança de taxa e mensalidade o SESI-SP deixou de ser o único Departamento Regional a oferecer ensino inteiramente gratuito. Essa medida foi tomada em função da necessidade de ampliar a oferta de vagas no Ensino Médio, criação de cursos técnicos e de investimentos na modernização das escolas. A seguir, imagens dos novos padrões de escolas da rede. Respectivamente, padrão horizontal e vertical.

\footnotetext{
${ }^{16} \mathrm{Cf}$. Py at al, 2011.
} 


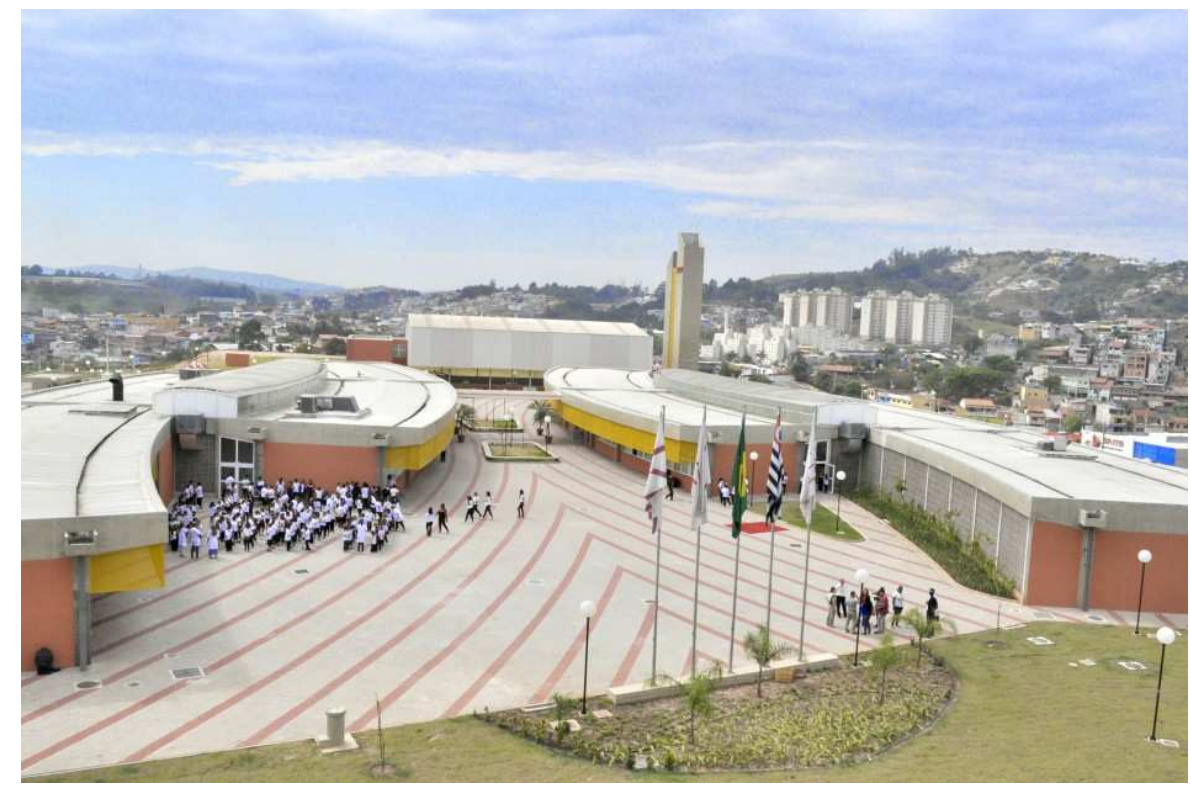

Figura 11 - Escola SESI de Cajamar (Disponível em:

http://www.cajamar.sp.gov.br/v2/?exibe=imprensa\&canal=texto\&id=2290 Acesso em: 23 de Abr. 2015)

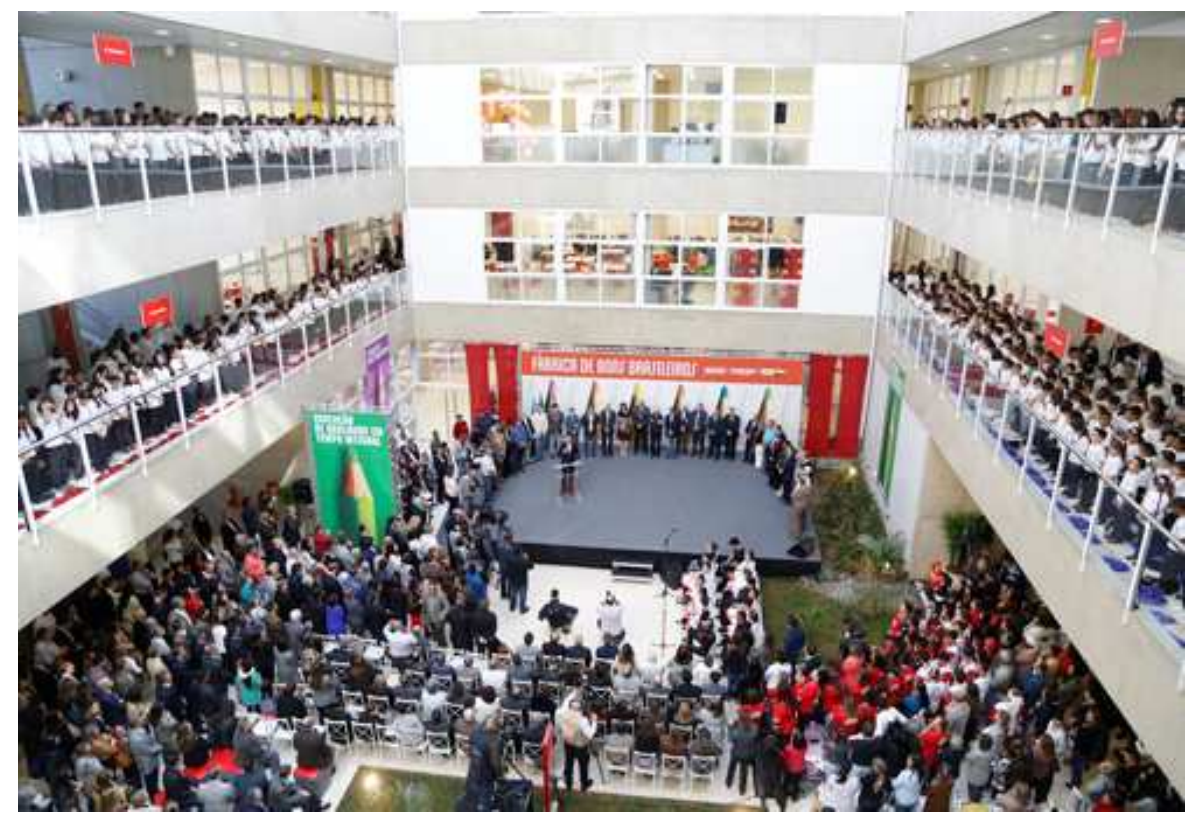

Figura 12 - Inauguração da escola SESI de Franca. (Disponível em: http://www.sesisp.org.br/hArquivo.ashx?Url=11589 Acesso em: 23 de Abr. 2015)

$\mathrm{O}$ acirramento das críticas à progressão continuada em diferentes instâncias na sociedade e também na Rede SESI-SP, as dificuldades e críticas dos professores quanto à atribuição dessas menções que, a seu ver, não estimula os estudantes - pois "aquele se dedica muito tem a mesma 'nota' daquele que se dedica apenas o suficiente" - levou a mudanças na atribuição de menções, conforme Regimento Comum Escolar da Rede SESI-SP (2007): 
Art. 35 No Ensino Fundamental, as atividades de avaliação formativa serão expressas por PS (Progressão Satisfatória) e PI (Progressão Insatisfatória), nos diferentes instrumentos de avaliação no decorrer das etapas.

Art. 36 Os resultados da avaliação classificatória do desempenho do educando na etapa de cada ciclo do Ensino Fundamental, serão expressos pelas menções:

I - PSA - Progressão Satisfatória com Aprofundamento - Atingiu as expectativas de aprendizagem da etapa e meta de leitura;

II - PSP - Progressão Satisfatória Plena - Atingiu as expectativas de aprendizagem da etapa;

III - PE - Progressão Essencial - Atingiu as expectativas de aprendizagem essenciais da etapa;

IV - PI - Progressão Insatisfatória - Não atingiu as expectativas de aprendizagem essenciais da etapa;

V - PNA - Progressão Não Avaliada - Não atingiu as expectativas de aprendizagem essenciais da etapa por não ter realizado as atividades pedagógicas previstas no período

Entretanto, na revisão do Regimento Comum, publicado em 2010 as menções são abolidas e substituídas por notas de 1,0 a 10,0:

Art. 28. O processo avaliativo no Ensino Fundamental, no médio e na educação profissional técnica de nível médio obedecerá aos seguintes procedimentos:

I - as atividades de avaliação serão expressas por notas de 1,0 (um) a 10,0 (dez), graduadas numa escala de 0,5 (cinco décimos) em 0,5 (cinco décimos);

II - ao final de cada etapa, deverá ser aferida a média aritmética das notas atribuídas nas avaliações considerando-se o décimo, sem arredondamento;

Art. 29. Ao final de cada ano letivo, será aferida a média aritmética das médias das etapas considerando-se o décimo, sem arredondamento. (SESI-SP, 2010)

Apesar dessa mudança, no Art. 25 destaca-se:

A avaliação na rede escolar SESI-SP deverá refletir o desempenho global do educando, considerando-se que há ritmos e processos de aprendizagem diferentes.

Um dos maiores incentivadores dessa mudança foi o Sr. Fernando Antonio Carvalho de Souza, recém-nomeado diretor da Divisão de Educação e articulador das reestruturações pelas quais passou a divisão desde então. Com uma visão que alia a busca por resultados e otimização dos recursos o novo diretor passou a orientar os processos da rede visando maior racionalização e redução de custos, como a mudança no processo de matrículas que, até então, era feito nas escolas e passou a ser realizado via internet, implementação de iniciativas de formação à distância, aumento da carga horária dos professores, e, consequente redução de funcionários onde fosse possível, delegação de maior autonomia administrativa às unidades escolares e incentivo ao crescimento do Sistema SESI-SP de Ensino. 
Assim como ocorreu na rede pública do Estado de São Paulo, a racionalização dos custos da educação escolar, que já vinha em curso, resultou na redução do número de escolas (de 183 em 2001, para 155 em 2013).

A diversificação dos serviços prestados pela Divisão de Educação do SESI-SP leva à sua reestruturação em 2012. Nesse processo, ainda, entre 2012 e 2013, foram implantadas as Supervisões Estratégicas de Atendimento (SEA) (Figura 13), responsáveis pela formação continuada, incentivo às ações de saúde, ciência e tecnologia, cumprimento da legislação e organização escolar ${ }^{17}$ e onde existem equipes responsáveis pela relação com as prefeituras. Em cada uma dessas SEA há técnicos encarregados em trabalhar com a formação continuada dos professores de cada uma das áreas do conhecimento (Ciências Humanas, Linguagens e Códigos, Informática Educacional, Ciências da Natureza e Matemática, além de um pedagogo que é responsável pelo acompanhamento dos professores de $1^{\circ}$ ao $5^{\circ}$ anos e da educação infantil).

No que diz respeito à formação dos professores, analistas técnico-educacionais especialistas em cada uma das áreas do conhecimento (Ciências Humanas, Ciências da Natureza e Matemática e Linguagens e Códigos) ficaram responsáveis por acompanhar os professores nas escolas e realizar encontros regionais com, conforme orientações da DEC, disponibilidade orçamentária e acordos com o sindicato dos professores.

Esse projeto passou recentemente por uma reestruturação. Era esperado que a maior proximidade entre analistas pedagógicos e professores resultasse em um salto de qualidade no ensino oferecido nas escolas do SESI-SP, mas, passados três anos da instalação desse modelo de formação de professores, o que se viu foram avanços pouco significativos ou até mesmo retrocesso, não justificando o investimento realizado. Os porquês desse "insucesso" demandariam uma análise mais aprofundada, talvez em novo trabalho, mas é possível levantar hipóteses para o fato da presença do Analista Técnico Educacional como agente formador de professores na escola não tenha surtido os efeitos esperados, por: 1 - irregularidade do acompanhamento devido ao número de escolas e profissionais a serem acompanhados e, muitas vezes, à necessidade de grandes deslocamentos para fazê-lo; 2 - visão, por parte da direção escolar e coordenação pedagógica de que a existência do Analista, lhes eximia da responsabilidade de desenvolver ações formativas junto aos professores; 3 - a formação 
específica do Analista, não lhe possibilitou orientar os professores em relação ao trabalho com temas específicos de seus componentes curriculares dentro da área de conhecimento; 4 - o Analista foi visto como um elemento estranho à escola, um representante da Sede e isso não contribuiu para que se estabelecesse uma relação de confiança, prejudicando o processo formativo e, 4 - o projeto, em sua concepção, não atendia às necessidades formativas que, se acreditava, fossem necessárias, e não organizou a articulação entre os profissionais envolvidos no processo formativo, como Coordenadores Pedagógicos, Analistas Técnicos Educacionais (da Sede e das SEA's) e Supervisores Educacionais.

Com isso, embora, em geral, três anos seja pouco tempo para avaliar um projeto dessa magnitude em educação, optou-se por oferecer aos analistas das SEAs a oportunidade de regressar à sala de aulas como professores e, com isso, também, reduzir custos. 


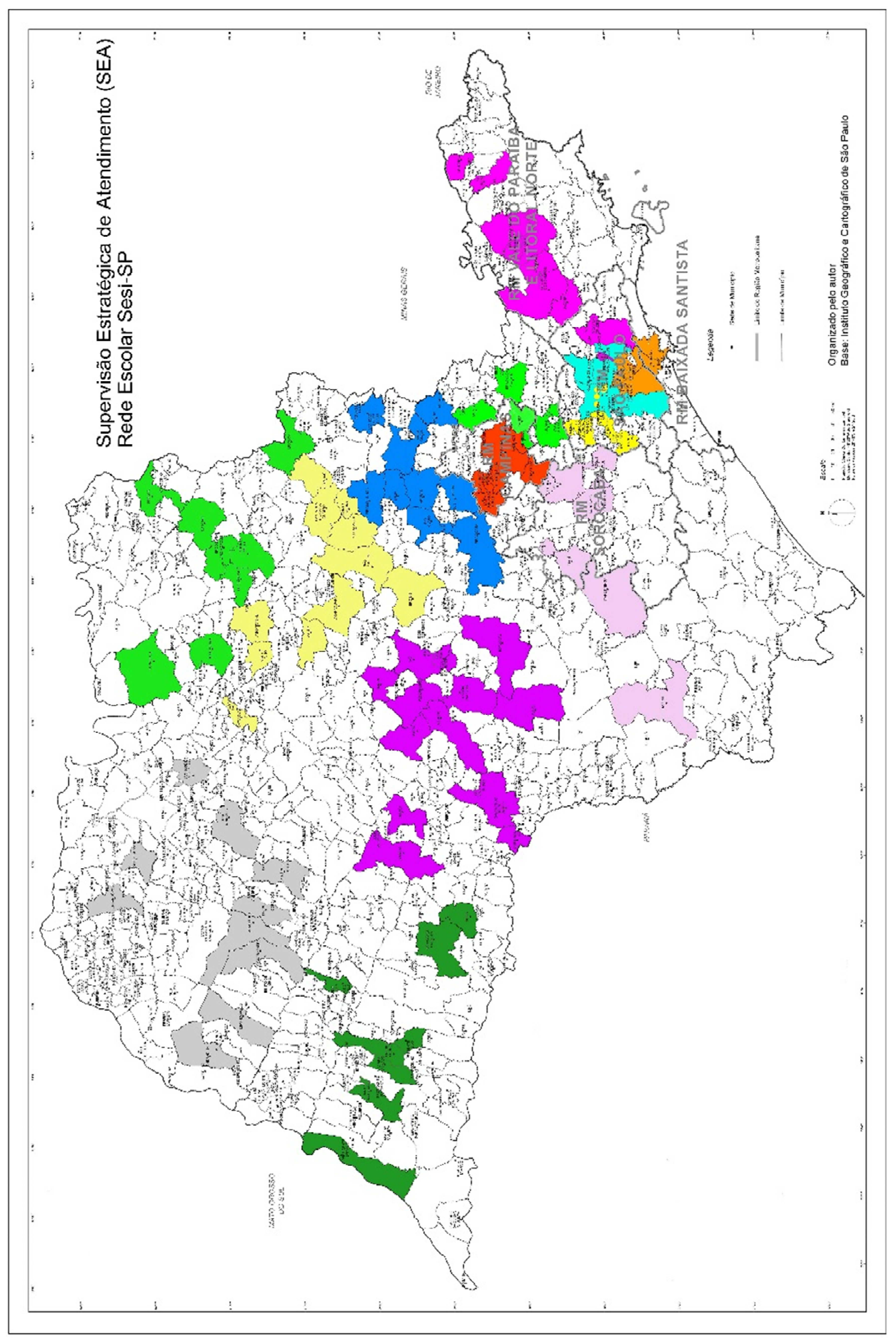

Figura 13- Supervisão Estratégica de Atendimento (SEA) 
As SEAs continuam existindo, agora com foco no trabalho junto aos Coordenadores Pedagógicos, Analistas de Suporte em Informática (responsáveis pelos projetos de robótica e funcionamento dos laboratórios de informática) e na formação dos professores dos municípios conveniados ao Sistema SESI-SP de Ensino.

Também como parte desse processo de reestruturação a Gerência de Avaliação da Divisão de Educação foi extinta, alguns analistas técnico-educacionais e uma supervisora foram remanejados para a Gerência de Currículos e Programas, que passou a ser denominada Gerência de Educação Básica (GEB). Promove-se, assim, mais que um corte de despesas, a fragilização das ações de avaliação institucional e maior centralização das decisões.

A revisão do Referencial Curricular da Rede Escolar SESI-SP para o Ensino Fundamental que ocorreu entre os 2013 e 2015, reafirmou a concepção de ensino, considerada sociointeracionista e destaca como autores de referência, Jean Piaget, Lev Semenovitch Vigostki, Henri Wallon e David Ausubel como norteadores das propostas dos componentes curriculares. Uma medida importante tomada nessa revisão foi a separação das expectativas de ensino e aprendizagem do documento de referência. Isso porque, entendeu-se que as expectativas podem ser revisadas com mais frequência, considerando as demandas da rede e a legislação, enquanto que o Referencial, em si, representa a identidade pedagógica da rede. Em outras palavras, pode-se dizer que, com isso, o currículo se torna mais flexível para se adequar às demandas institucionais, sem que sejam necessárias profundas reformulações em seus referenciais.

O primeiro resultado desse trabalho foi a revisão e publicação do livro didático do $6^{\circ}$ ano, acompanhado dos novos livros de textos: "Muitos Textos....Tantas Palavras" e “Orientações Didáticas do Movimento do Aprender no Sistema SESI-SP de Ensino”. Essa revisão, além de se basear no texto revisado do referencial curricular, tomou como referência, também, uma consulta realizada junto a professores, estudantes e analistas pedagógicos dos diferentes componentes curriculares.

Como resultado, o livro didático, foi enriquecido em conteúdo e atividades (Figura 14), de forma que a contribuir para o enriquecimento do trabalho do professor, mas também pode ser visto como um maior direcionamento desse trabalho. 


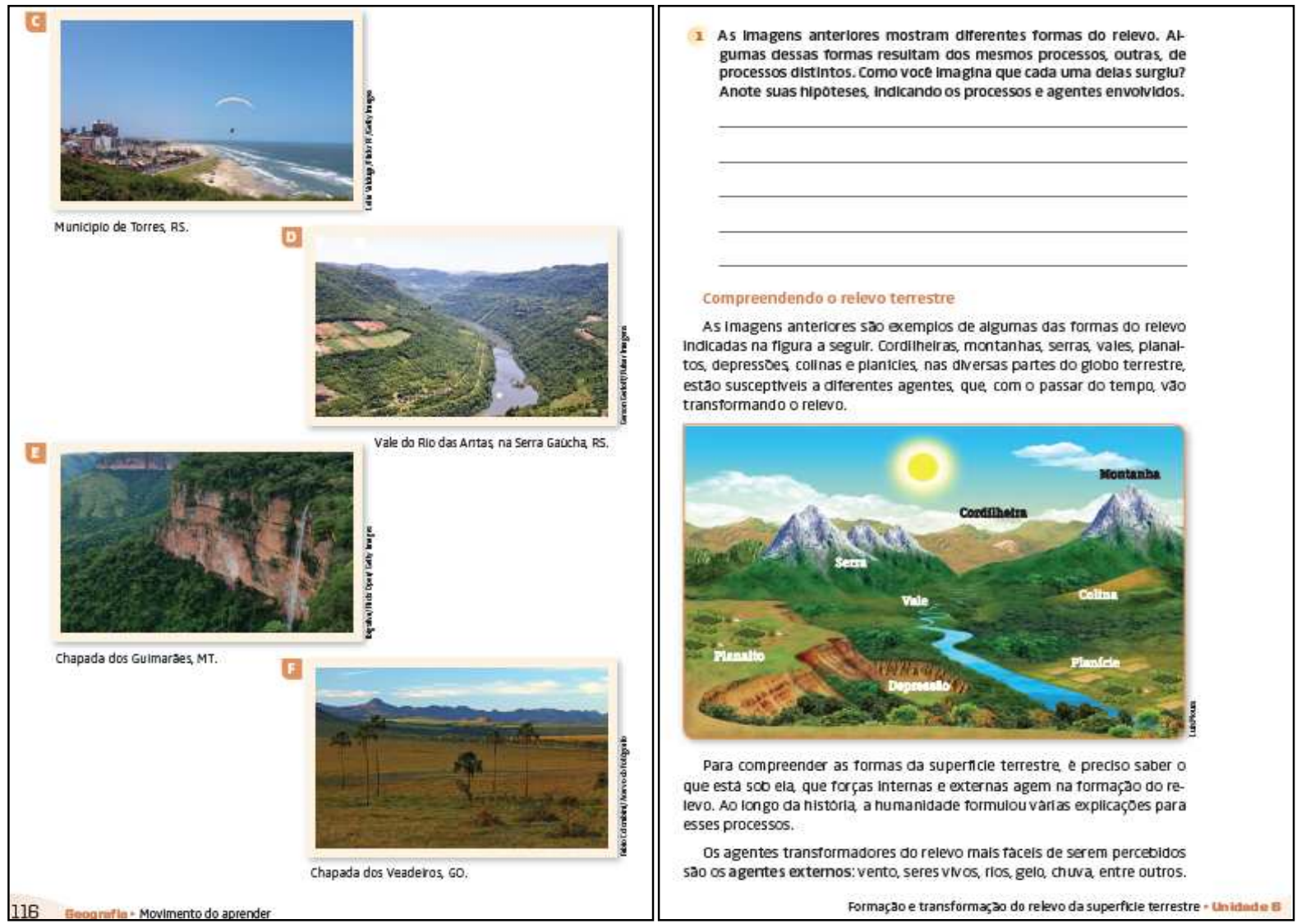

Figura 14 - Páginas do novo livro didático de Geografia - $6^{\circ}$ ano.

Destaca-se, ainda que os livros do $7^{\circ}, 8^{\circ}$ e $9^{\circ}$ ano foram enviados à editora SESI-SP, mas devido a divergências quanto aos procedimentos e a questões orçamentárias, sua publicação para o ano letivo de 2016 encontra-se em aberto. 


\section{CAPÍTULO 3 - DE REDE, A SISTEMA SESI-SP DE ENSINO}

O objetivo deste capítulo é analisar a reorientação do Projeto Educacional do SESI-SP com sua entrada no mercado de prestação de serviços educacionais.

Primeiramente, é importante destacar que para Saviani (1999), um sistema de ensino se caracteriza pela ordenação de elementos necessários para atingir determinados objetivos educacionais. $\mathrm{O}$ autor destaca, ainda, a necessidade de elaboração de um planejamento coerente com os valores da instituição.

No que diz respeito à constituição do Sistema SESI-SP de Ensino, a criação do Fundo de Manutenção e Desenvolvimento do Ensino Fundamental e de Valorização do Magistério (FUNDEF) ${ }^{18}$ e, posteriormente do Fundo de Manutenção e Desenvolvimento da Educação Básica e de Valorização dos Profissionais da Educação (FUNDEB) ${ }^{19}$ possibilitaram ao SESI-SP oferecer serviços educacionais às prefeituras do Estado de São Paulo. Destaca-se que conforme previsto no artigo 70 da Lei no 9.394/96 da Lei de Diretrizes e Bases da Educação Nacional (LDB) as prefeituras podem gastar $40 \%$ dos recursos do fundo com despesas de Manutenção e Desenvolvimento do Ensino (MDE). Entre essas despesas destaca-se a com formação continuada de professores da Educação Básica,

voltada para a atualização, expansão, sistematização e aprofundamento dos conhecimentos, na perspectiva do aperfeiçoamento profissional que, de forma contínua, deve ser promovido pelos Estados, Distrito Federal e Municípios mediante programas com esse objetivo, assegurados nos respectivos Planos de Carreira e Remuneração do Magistério. (FUNDEB, 2013, p. 23)

Com isso, o SESI-SP ingressa em um mercado que durante quase 20 vem transferindo recursos públicos para a privada, que aumenta seus lucros sem demonstrar avanços na qualidade do ensino ou na formação de professores. Para conquistar parte desse nicho do mercado de formação continuada de professores o SESI-SP passa a oferecer aos municípios, desde 2009:

a) Referencial Curricular da Rede Escolar SESI-SP - o mesmo documento que norteia as práticas pedagógicas dos professores e o currículo da rede SESI-SP;

\footnotetext{
${ }^{18}$ Criado em 1996 pela Emenda Constitucional n. 14 e regulamentado pela Lei n. 9.424/96, passou a vigorar em $1^{\circ}$ de janeiro de 1998.

${ }_{19}$ Criado pela Emenda Constitucional no 53/2006. Regulamentado pela Lei $n^{\circ} 11.494 / 2007$ e pelo Decreto $n^{\circ}$ 6.253/2007 para substituir o Fundef.
} 
b) Formações com os profissionais da Educação (equipe técnica, diretores escolares e coordenadores pedagógicos) com duração de 6 a 8 horas cada - objetivando contribuir para melhores práticas de gestão, acompanhamento e orientação dos professores;

c) Quatro encontros anuais para formação de docentes, com 4 horas de duração cada - ressaltando aspectos específicos dos componentes curriculares e áreas do currículo, com foco na proposta pedagógica expressa nos Referenciais Curriculares e no Material Didático da Rede SESI-SP;

d) Monitoramento in loco por escola - Acompanhamento da implementação das ações discutidas nos encontros com os técnicos.

e) Material Didático para alunos e docentes - material da educação infantil ao $9^{\circ}$ ano do Ensino Fundamental, em muitos casos, objeto de discussão nos encontros de formação dos professores.

f) Certificado de participação nas Formações realizadas no decorrer do ano.

Assim, a partir de dados de agosto de 2013, os números do Sistema SESI-SP de Ensino podem ser organizados conforme a tabela, a seguir. Segundo informações do SESI, entre gastos com material didático para EF I e EF II e formação de professores gestores e educadores, o custo aproximado com a adesão ao Sistema SESI-SP de Ensino é de aproximadamente R\$ 170,00 por aluno ao $\mathrm{ano}^{20}$. 


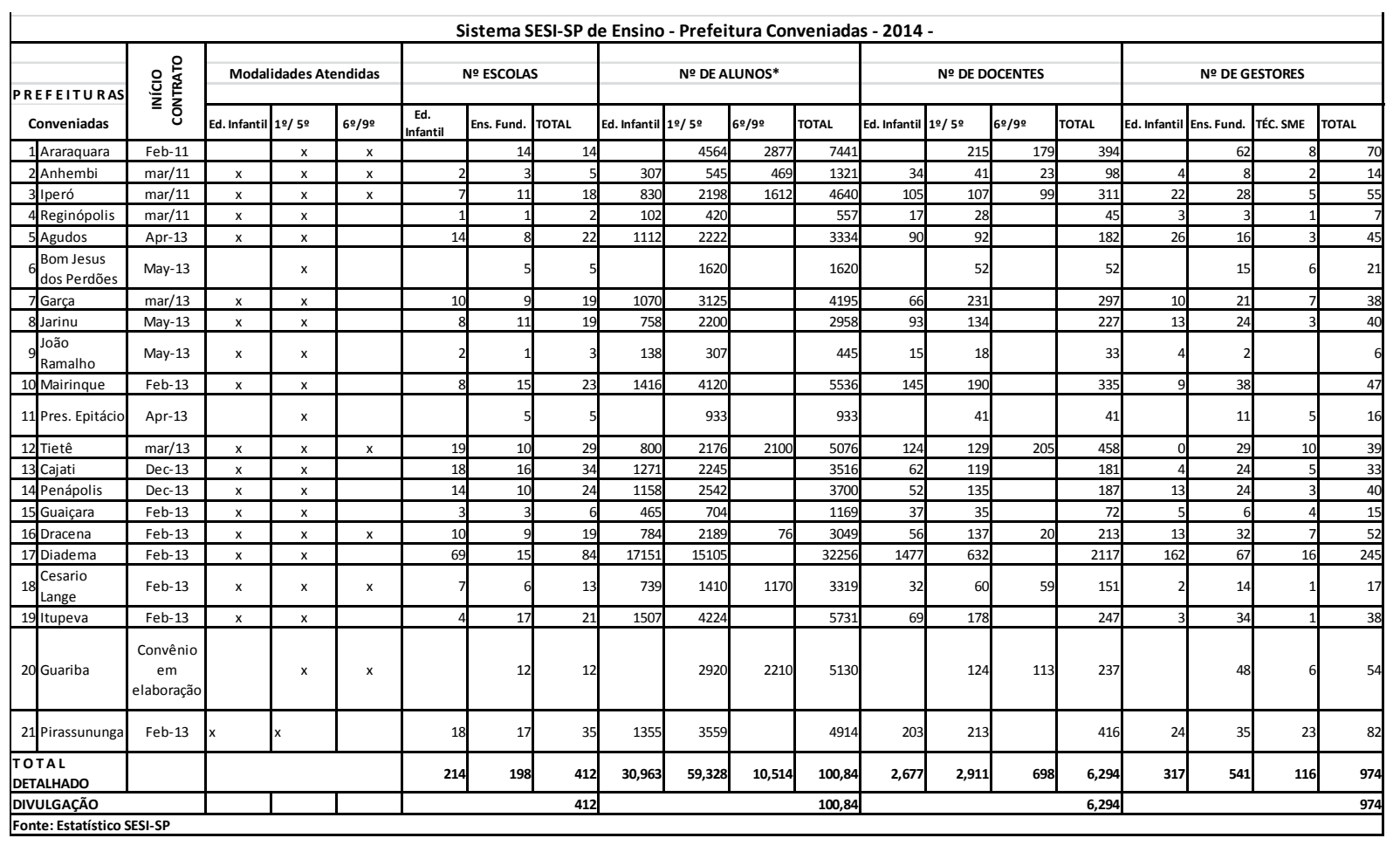

Quadro 2 - Prefeituras conveniadas ao Sistema SESI-SP de Ensino -2014

(Fonte: Estatístico - SESI-SP) -Observação: Total de alunos X 1.000 


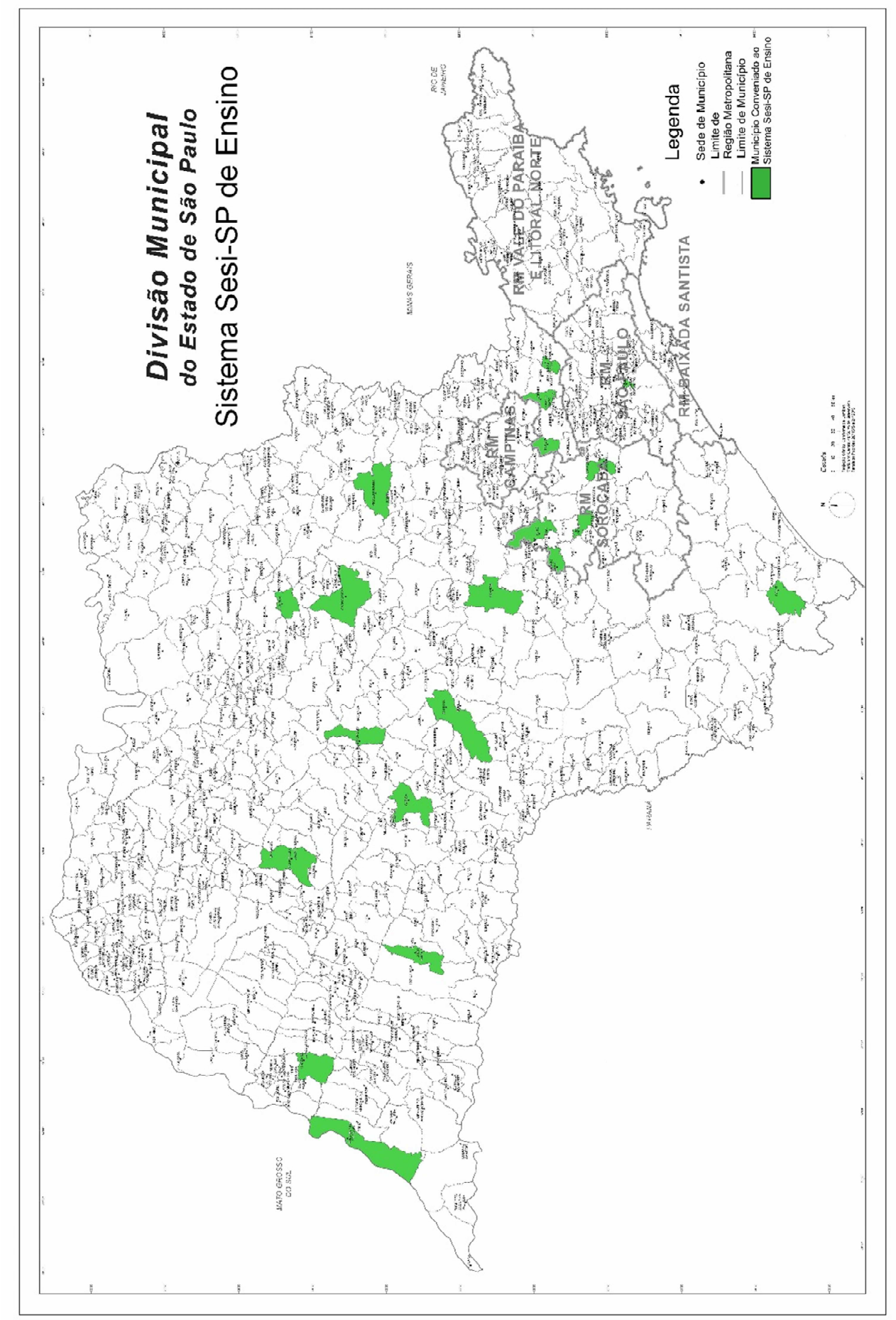

Figura 15 - Distribuição territorial dos municípios conveniados ao Sistema SESI-SP de Ensino 
A ampliação da oferta desses serviços contribuiu substancialmente para a reorganização da Divisão de Educação, conforme indicado anteriormente. Durante mais de um ano, devido à equipe reduzida de técnicos para realizar a formação dos professores, foi priorizada a formação presencial dos profissionais das prefeituras conveniadas. Com isso a formação de parte dos professores da rede SESI-SP passou a ser feita na modalidade EAD (Educação a Distância) através do portal da rede, coordenada pelos técnicos da DE, além da formação na unidade escolar, coordenada pelo coordenador pedagógico.

Contudo, a demanda pela formação presencial e, inclusive, de atendimento às prefeituras, levou a Superintendência do Departamento Regional do SESI-SP a lançar a resolução 29/12 (ANEXO 4), reestruturando a organização da Divisão de Educação e 11/13 (ANEXO 5) que, entre outras medidas, integrou as atividades culturais à Divisão de Educação a qual passou a se denominar Divisão de Educação e Cultura (DEC).

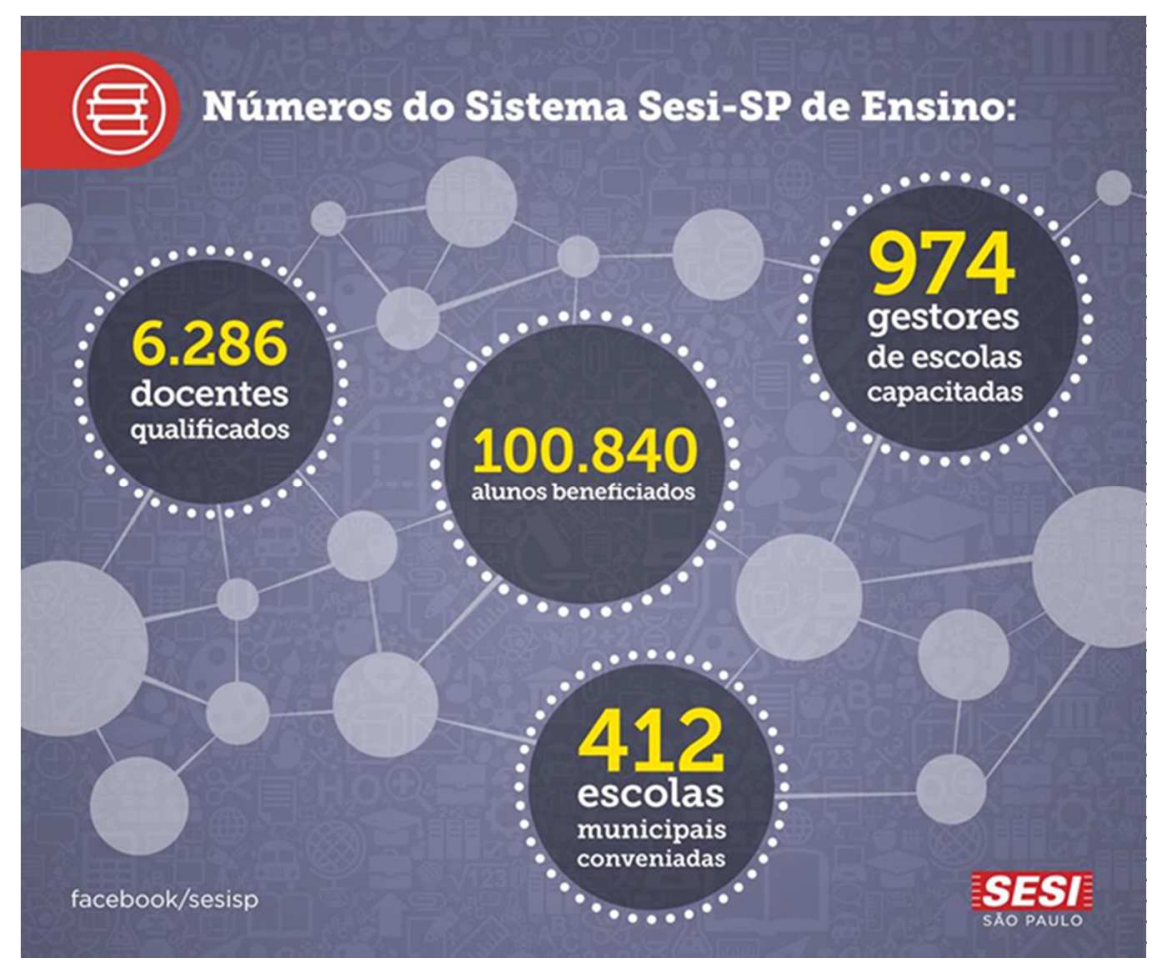

Figura 16 - Números do sistema SESI-SP de Ensino

(Fonte: https://www.facebook.com/SESIsp/photos_stream)

Com o crescimento do Sistema SESI-SP de Ensino, atualmente, o número de estudantes atendidos por esse serviço já supera o de estudantes matriculados em escolas SESISP. Para seus dirigentes, que não mencionam os reflexos políticos relacionados a esse crescimento, ao aderir ao Sistema, a prefeitura tem a possibilidade de ter todas as escolas do município utilizando a mesma metodologia de sucesso das escolas SESI-SP. Isso, então, exime a instituição de fazer investimentos em novas escolas e aumentar sua folha de pagamentos e, 
ainda assim, ampliar o alcance de suas ações, sua influência política e sua arrecadação. Essa observação, contudo, não tem o objetivo de desconsiderar ou desmerecer a importância do Sistema SESI-SP de Ensino, principalmente para os municípios menores do interior do estado, distantes de centros universitários, onde ainda é mais escassa a oferta de cursos presenciais para a continuidade dos estudos e aprimoramento dos professores. 


\section{CAPITULO 4 O TRABALHO DOS PROFESSORES E O ENSINO DE GEOGRAFIA}

Neste capitulo são apresentadas e analisadas as percepções de estudantes e Coordenadores Pedagógicos da Rede Escolar SESI-SP, cerca do trabalho dos professores, pois são os segmentos mais próximos dos professores em seu trabalho em sala de aula e sobre os quais recaem as ações oriundas das políticas e orientações da Divisão de Educação sobre a prática dos docentes. Além disso, é importante ouvir os estudantes, em primeiro lugar, porque são os sujeitos diretamente implicados no processo de ensino e aprendizagem e quem está mais apto a emitir um valor ou dimensionar o que está aprendendo e que tipo de ações contribuem para esse aprendizado. Já, o Coordenador Pedagógico, de forma geral é quem deve favorecer, na escola, o trabalho do professor, por meio da formação continuada ou, como indicam Lima e Santos (2007, p. 79) um assessor "permanente e continuada ao trabalho docente".

\section{1 - A VISÃO DOS COORDENADORES PEDAGÓGICOS}

O Coordenador Pedagógico é o profissional normalmente responsável por acompanhar e orientar o trabalho do professor na escola. Na rede escolar SESI-SP, destaca-se, nesse sentido ${ }^{21}$ :

Orientar, acompanhar e avaliar o desenvolvimento do trabalho docente, mantendo os devidos registros;

Orientar e avaliar o material didático solicitado ou preparado pelos docentes, bem como as produções pedagógicas dos discentes;

Acompanhar o desenvolvimento da proposta pedagógica e analisar e intervir nos planos de trabalho docente e diários de classe;

Analisar resultados do rendimento escolar dos alunos propondo ações de redimensionamento da prática pedagógica;

Participar, como agente integrador e articulador, da ação pedagógica e didática da Unidade Escolar, assessorando a administração da Escola na coordenação e na gestão de pessoas envolvidas no processo pedagógico;

\footnotetext{
${ }^{21}$ Atribuições do coordenador pedagógico - Gerência de Currículos e Programas - SESI-SP
} 
Durante encontro de formação com esses profissionais, apresentamos um questionário com três questões aos 231 Coordenadores Pedagógicos presentes (SILVA JR, 2012) com o intuito de reunir dados para uma pesquisa no Curso de Gestão Escolar e Coordenação Pedagógica da Universidade Gama Filho para obtenção do título de especialista, cujos resultados foram apresentados na monografia intitulada "O papel do Coordenador Pedagógico na formação dos professores de Geografia na Rede Escolar SESI-SP” (ANEXO 6):

01 - O que caracteriza um bom professor de Geografia

02 - Que ações [do professor de Geografia] mais contribuem para aprendizagem dos alunos?

03 - Quais os equívocos mais comuns na prática dos professores [de Geografia]?

Segundo os Coordenadores Pedagógicos (CP) da Rede Escolar SESI-SP22, normalmente um bom professor de Geografia se caracteriza por dar aulas dinâmicas, conhecer em profundidade o conteúdo, relacionar a teoria às questões do cotidiano e utilizar diferentes recursos tecnológicos (SILVA JR, 2012), pois, com isso, o estudante percebe de forma mais eficiente a contextualização dos conteúdos e se sente mais estimulado a participar da aula e aprender.

Entre os equívocos mais comuns no trabalho dos professores, os Coordenadores Pedagógicos destacam, por exemplo: colocar o estudante em uma postura passiva diante do conhecimento; utilizar a avaliação como uma forma de punição ao mau comportamento dos estudantes e ficar muito na teoria, sem relacionar os conteúdos com a realidade.

\section{2 - A VISÃO ESTUDANTES DO ENSINO FUNDAMENTAL E MÉDIO}

Como forma de levantar dados acerca de como os estudantes avaliam o trabalho de seus professores, estes foram convidados a responder um questionário visando identificar aqueles professores que consideram serem os melhores e suas características, para estabelecer comparação com a avaliação feita dos professores de Geografia. Esses dados foram coletados por meio de um questionário com perguntas fechadas e abertas, elaborado a partir das 
funcionalidades da Web 2.0 e ficou disponível para ser acessado pelos estudantes na Internet de 9 de setembro a 11 de outubro de 2013.

Os dados obtidos trouxeram elementos importantes para nossa reflexão acerca da formação dos professores e a relação entre eles e os estudantes. A tabela a seguir indica os números que esperávamos atingir.

\begin{tabular}{|c|c|c|}
\hline \multicolumn{3}{|c|}{ Escolas e número de estudantes potencialmente envolvidos na pesquisa } \\
\hline & Escolas SESI-SP & Estudantes \\
\hline Ensino Médio & 164 & 17.395 \\
\hline EF II & 174 & 36.511 \\
\hline Total & $174^{23}$ & 53.906 \\
\hline
\end{tabular}

Quadro 3 - SESI-SP - Escolas por nível de ensino

Ao todo, participaram da pesquisa 3.333 estudantes, mas as respostas de nove foram excluídas por não ter sido possível identificar a escola onde estudam ou o professor indicado como melhor. Sendo assim, foram consideradas 3.324 respostas válidas. Dessas, 2.216 são respostas de estudantes do Ensino Fundamental II, ou 6,07\% do total de estudantes desse nível de ensino, enquanto que a participação dos estudantes do Ensino Médio foi de $6.37 \%$ do total do nível de ensino.

A figura a seguir apresenta a relação entre escolas representadas na pesquisa e não representadas, segundo a SEA onde estão localizadas. Do total de escolas representadas na pesquisa, 12 delas contaram com apenas uma resposta, 4 localizadas na SEA Ermelino Matarazzo.

\footnotetext{
${ }^{23} 174$ é o número de escolas da Rede Escolar SESI-SP que oferecem Ensino Fundamental ou Ensino Médio, ou ambos. Entre essas escolas, apenas 10 não têm Ensino Médio.
} 


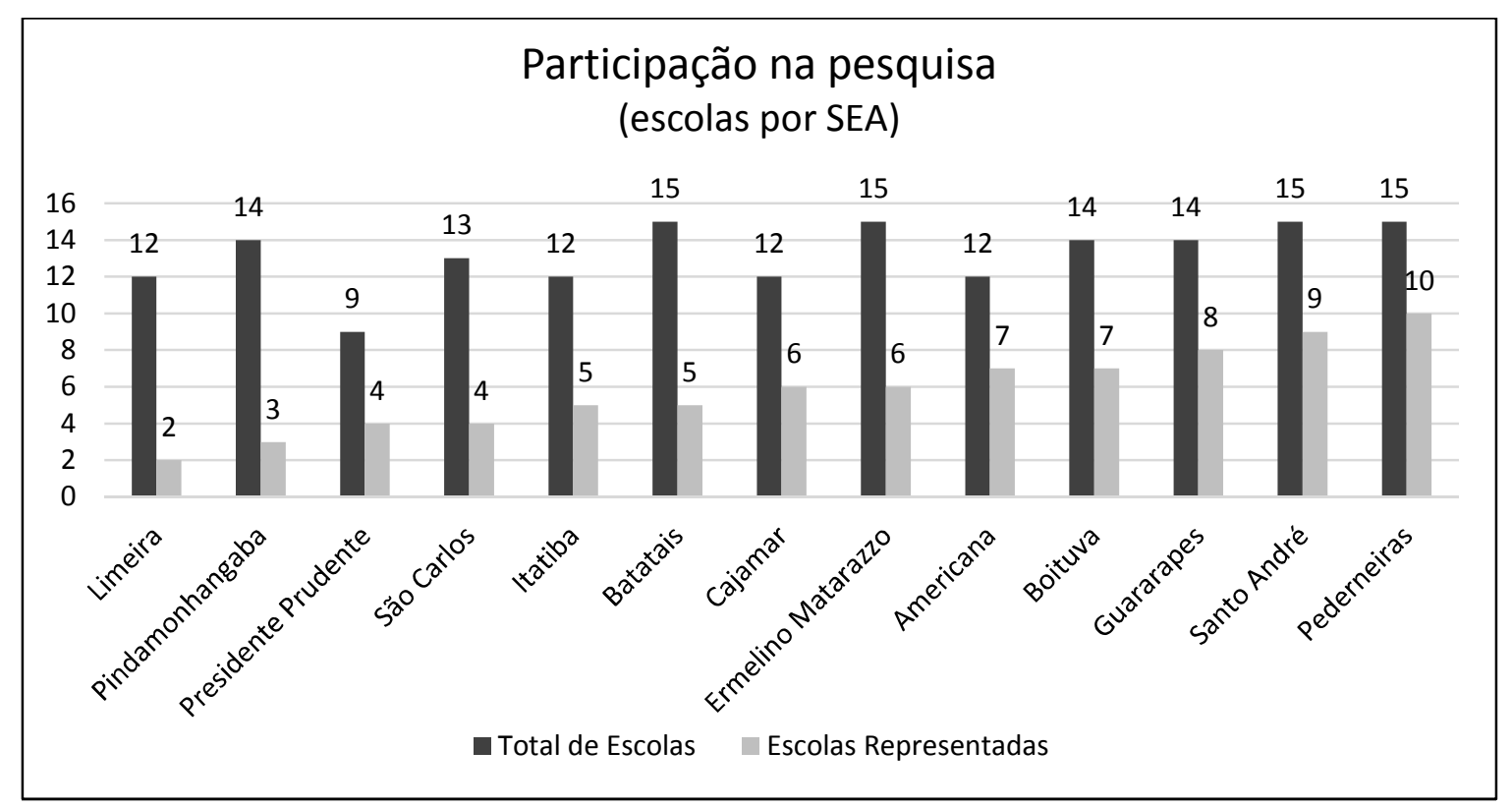

Figura 17 - Participação das escolas (por SEA)

A distribuição espacial das escolas representadas na pesquisa pode ser observada nas figuras a seguir:

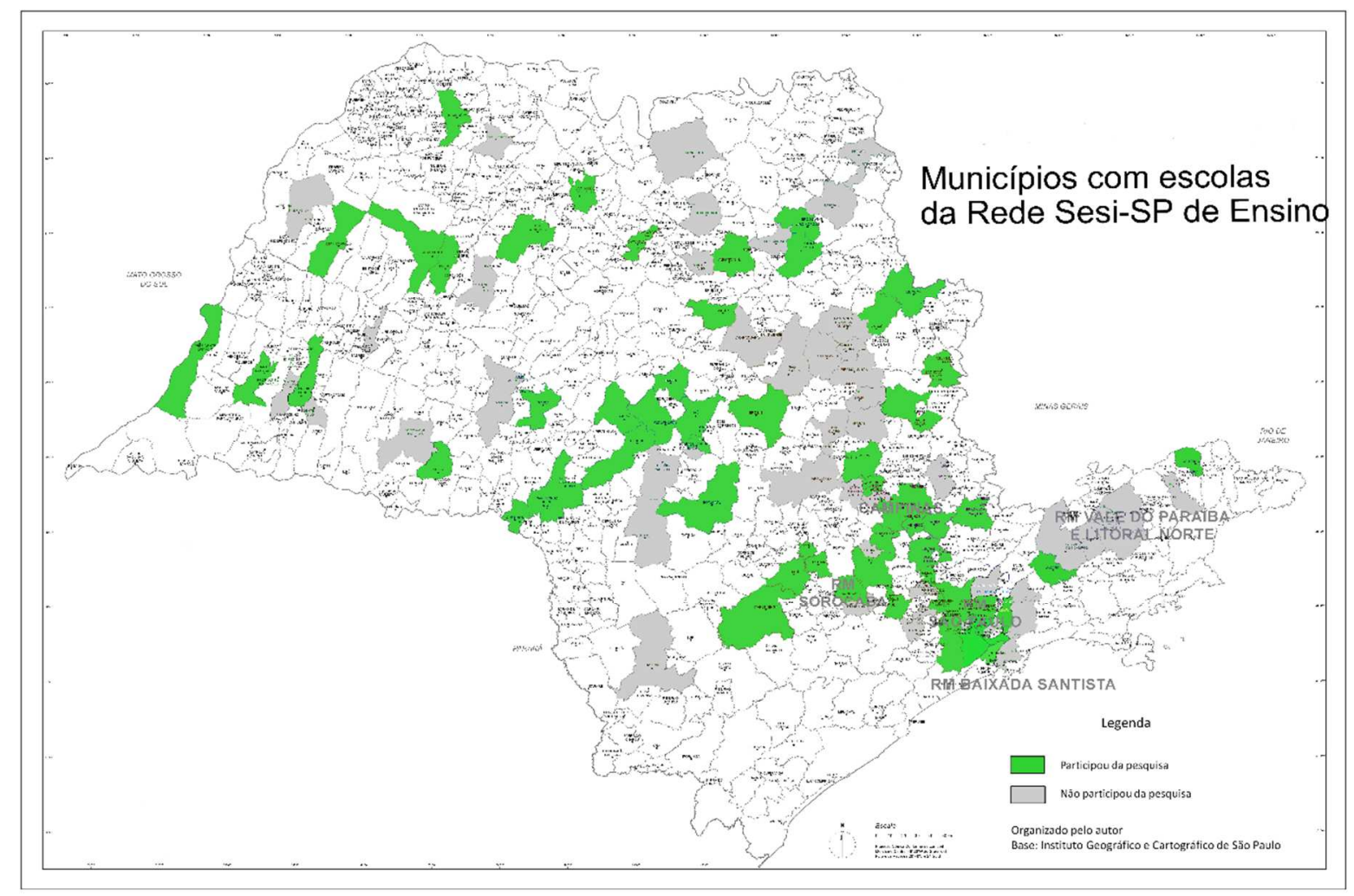

Figura 18 - Escolas representadas na pesquisa 


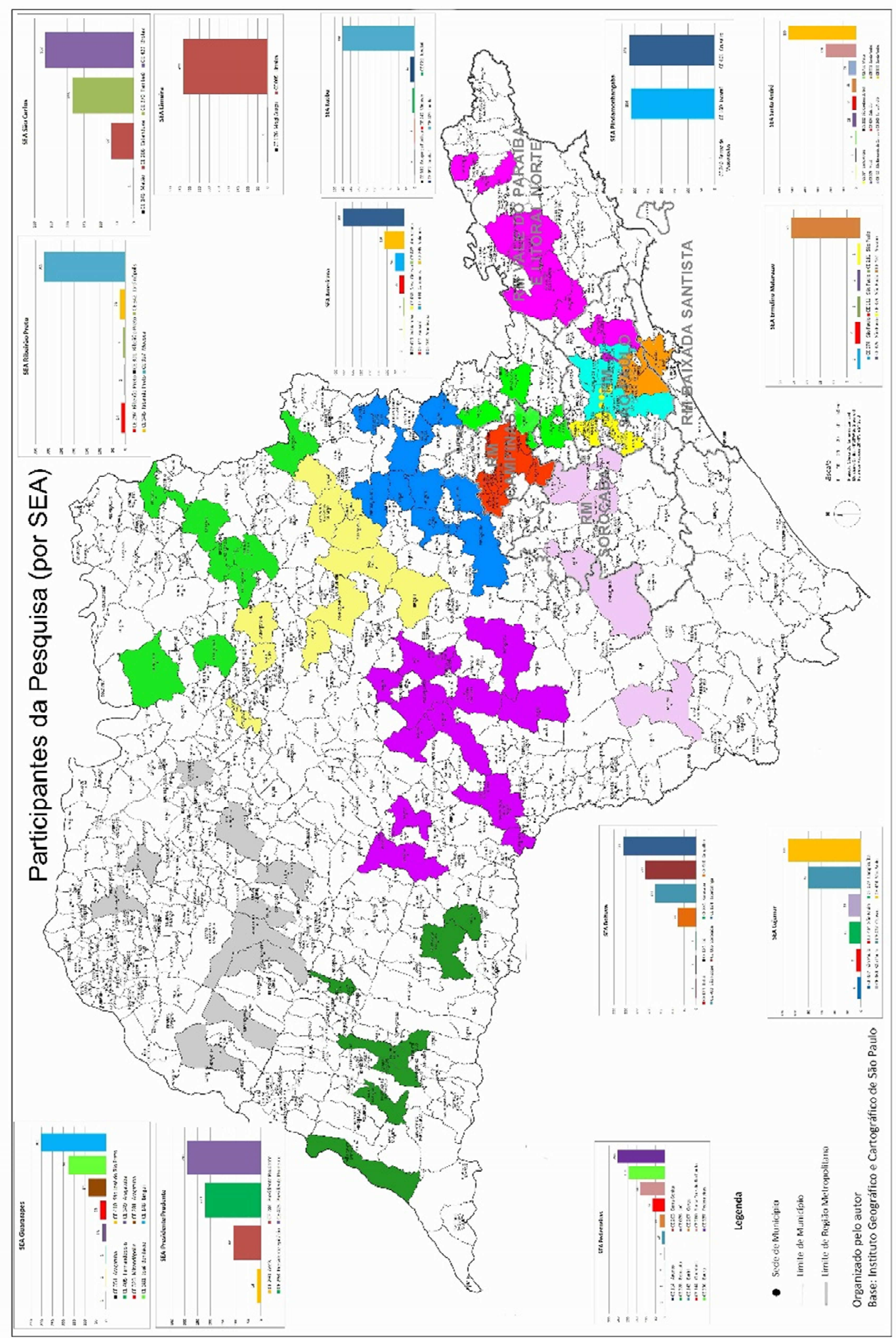

Figura 19 - Distribuição espacial das escolas representadas na pesquisa (por SEA) 
Os dados apresentados a seguir, demonstram a queda da participação dos estudantes a partir do $8^{\circ}$ ano. A diferença entre estes e os participantes que estavam no $3^{\circ}$ ano do Ensino Médio é superior a 50\%. Entre as hipóteses possíveis para isso, considera-se que a indisponibilidade de horário para utilização do laboratório de informática seja uma das mais prováveis, além do fato de parte desses estudantes, sobretudo a partir do $2^{\circ}$ ano, já cursarem o ensino técnico no contra turno e selecionarem com mais critérios as atividades desenvolvidas no interior da escola ou relacionadas a ela, além da menor disponibilidade de tempo.

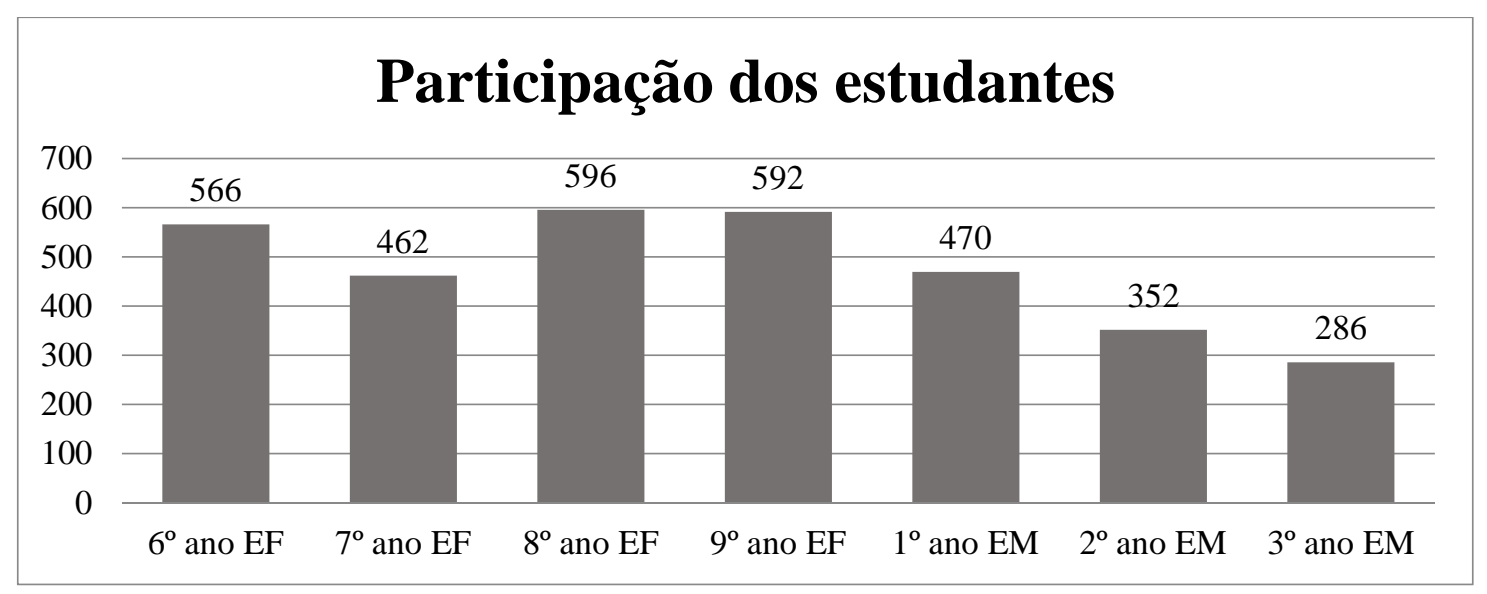

Figura 20 - Quantidade de alunos participantes da pesquisa, por ano.

Os resultados obtidos a partir desses dados indicam que os professores mais bem avaliados pelos estudandes são os de Matemática, tanto no EF II, quanto no Ensino Médio (Figuras 6 e 7) ${ }^{24}$. Esse é um dado bem interessante, uma vez que é bastante comum eleger-se a Matemática como uma das disciplinas mais rejeitadas, o que poderia fazer com que os docentes dessa área, não fossem bem avaliados pelos estudantes.

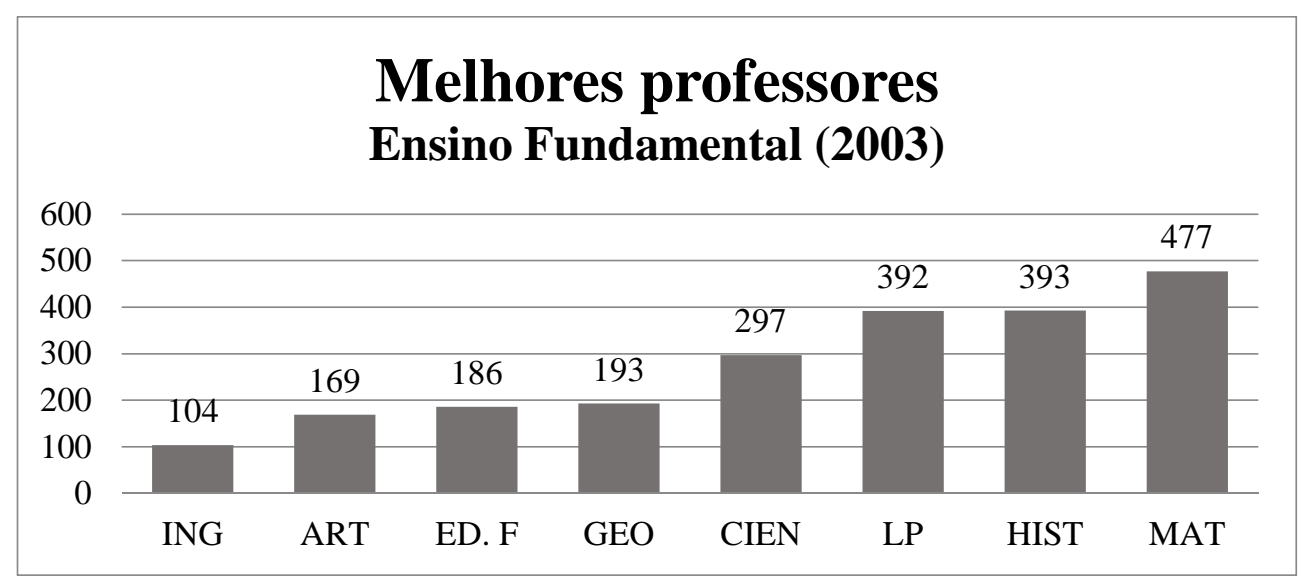

Figura 21 - Melhores professores que lecionaram no EF II no primeiro semestre de 2013, segundo os estudantes.

${ }^{24}$ Tabulação geral - ANEXO 6 
Por outro lado, esperava-se que os professores de Geografia estivessem entre os mais bem avaliados pelos estudantes, devido às características da disciplina que possibilita abordagens diversificadas, tanto em sala de aula quanto fora dela. Essa constatação contrária ao que se esperava, numa primeira análise, pode revelar a importância que os estudantes dão a Matemática e Língua Portuguesa que têm conteúdos mais cobrados nas avaliações externas. Outra hipótese poderia estar relacionada à maior carga horária da disciplina, prevista na matriz curricular, o que pode favorecer os vínculos entre docentes e estudantes. Contudo, isso não bastaria para essa disparidade na avaliação. Uma característica bastante destacada é que os professores de Matemática indicados como sendo os melhores explicam o conteúdo mais de uma vez, até o estudante entender. Essa mesma característica também foi valorizada nos professores de Geografia indicados como melhores. O que pode ser percebido em respostas como: "Ela me ajuda a entender alguma coisa quando tenho dificuldade" (sobre o professore de Geografia), “Não tem preguiça de explicar, e se for preciso repete a explicação.” (sobre o professor de Matemática).

No Ensino Médio, a preferência dos estudantes pelos professores de Matemática se manteve e a avaliação dos professores de Geografia foi significativamente inferior, como indica a figura a seguir.

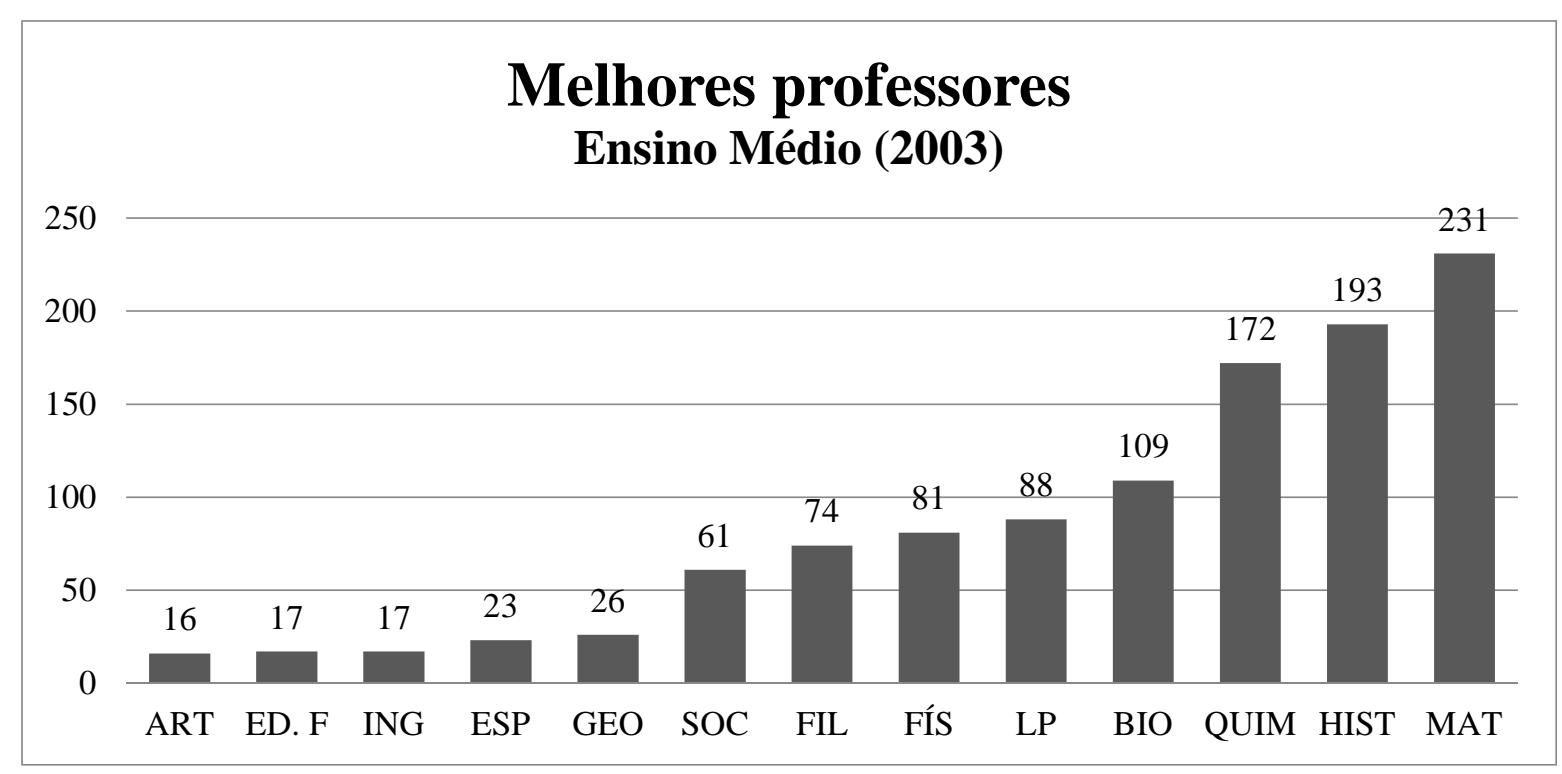

Figura 22 - Melhores professores que lecionaram no Ensino Médio no primeiro semestre de 2013, segundo os estudantes.

Como não foi solicitado que indicassem o professor com o qual "aprenderam menos", não foi possível levantar hipótese quanto à disparidade na avaliação entre os professores. $\mathrm{O}$ número de aulas, no Ensino Médio, poderia ser um dos fatores para essa diferença, mas a avaliação dos professores de História coloca em dúvida essa hipótese uma vez que tem o mesmo 
número de aulas que Geografia e Inglês, duas (2) aulas semanais em cada ano. Como foi permitido aos estudantes indicarem apenas uma opção, conclui-se, então, que os professores de Matemática e de História se destacam entre os demais no que se refere à percepção dos estudantes quanto à colaboração para o desenvolvimento de seu aprendizado, o que não significa que os demais sejam considerados maus professores.

Ao tomar como referência as respostas à questão sobre características que levaram os estudantes a indicarem o professor como o melhor, as frases foram sintetizadas em palavras ou expressões e, com elas foi elaborada uma nuvem de palavras com a utilização do site www.jasondavies.com/wordcloud/about/. Nessa ferramenta as palavras são contadas e quanto mais se repetem, elas se destacam na nuvem, tanto no tamanho, quanto na disposição (mais ou menos centralizada).

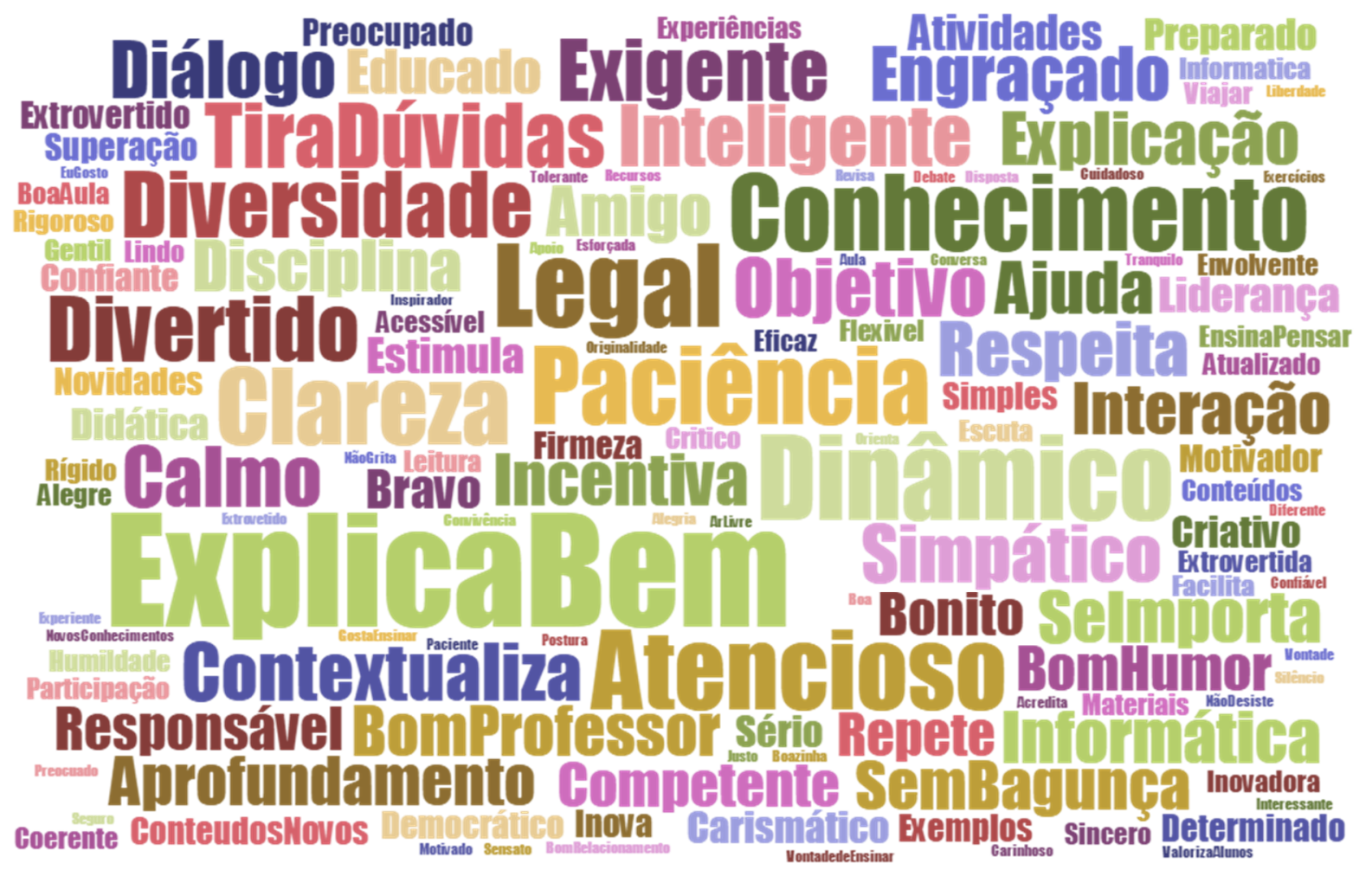

Figura 23 - Característica do bom professor

Da mesma forma, as ações dos professores ou situações em sala de aula, que os estudantes consideram atrapalhar a aprendizagem, foram transformadas em nuvem de palavras no mesmo site e se obteve o resultado apresentado na imagem a seguir. 


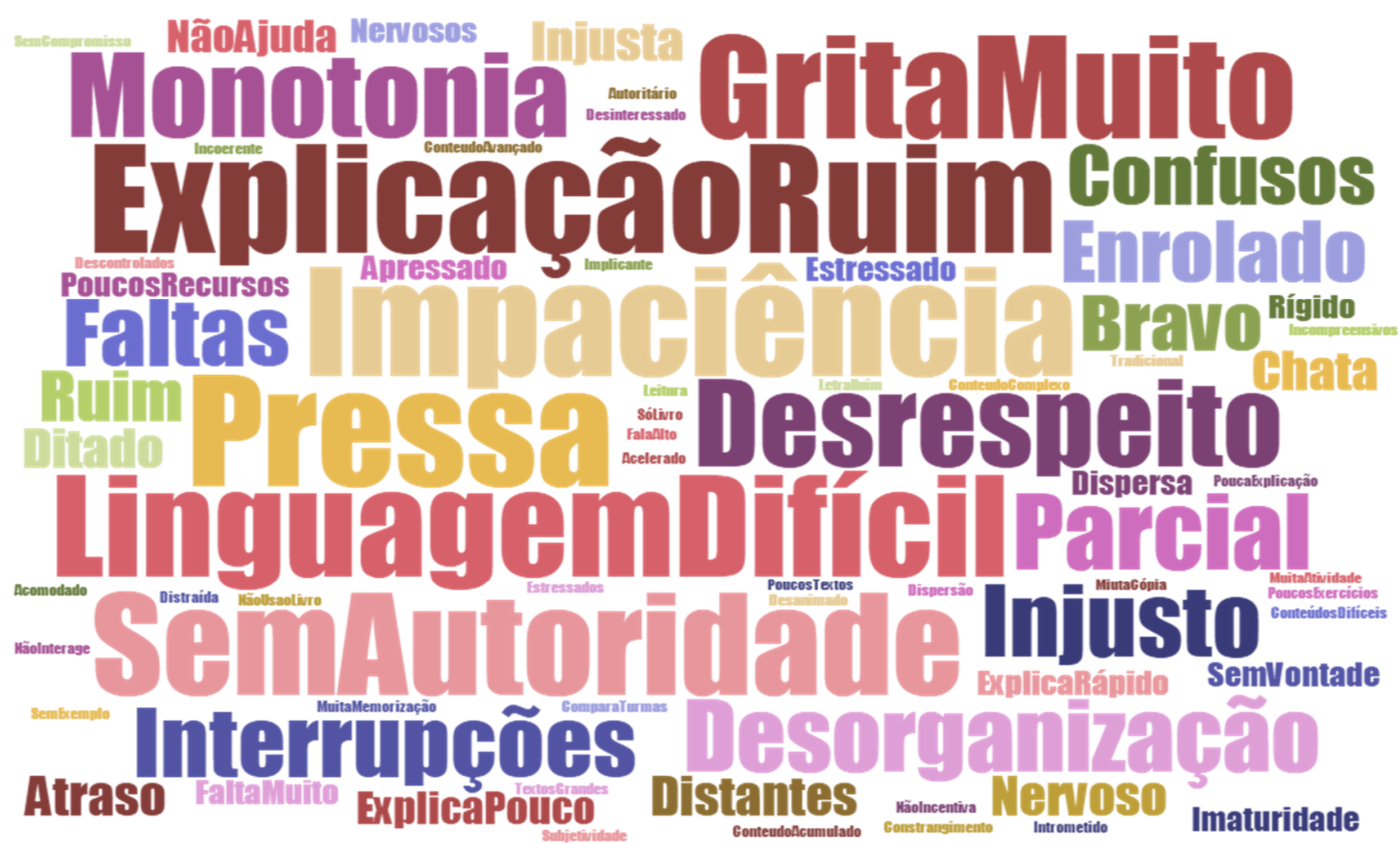

Figura 24 - Ações ou situações que atrapalham o aprendizado

A partir da análise das nuvens de palavras, como os resultados apresentam-se de forma visual e as respostas mais indicadas pelos estudantes aprarecem em destaque, podemos criar um referencial de análise. Esse referencial será baseado, inicialmente, em dois eixos centrais: Emocional e Comunicativo. Entretanto, para continuar essa análise, cabe explicar de forma mais detalhada como cada um desses eixos se configuram e quais são as suas referências, assim temos:

Eixo 1 - Emocional: aqui, elencamos as respostas que tenham como cerne o gosto e o emocional do estudante, entendidos aqui como característica de empatia e que na maioria das vezes são de dificil mensuração, no caso apresentado destacamos as posititivas e as negativas. São elas:

Positivas: É paciente, dinâmico, atencioso e tem empatia.

Negativas: É impaciente, agressivo, demora muito no mesmo conteúdo, dá aulas monótonas.

Essas são caracteristicas apresentadas por estudantes do Ensino Fundamental II e do Ensino Médio, e dessa forma os conceitos encontram-se sempre dentro da definição mais usual dos estudantes, não trazendo em sua maioria a questão do conceito amplo do termo,e nem mesmo sentido oculto. Essa informação é importante uma vez que uma pesquisa mais aprofundada poderá servir de base para ampliar o grau de compreensão que o estudante pode 
ter do processo de ensino e aprendizagem como um todo, o que poderia acrescentar um novo panorama sobre a questão da qualidade da aula.

Eixo 2 - Comunicativo: nesse eixo encontramos questões acerca da linguaguem e da comunicação entre o professor e estudante. Nesse caso temos um panorama da forma como o estudante enxerga o professor e quais são os elementos relevantes na comunicação entre eles. Assim temos:

Positivas: Se comunica com clareza, ouve os estudantes, trabalha os conteúdos de forma coerente e coesa.

Negativas: Se comunica com dificuldade, é desorganizado, grita, entre outros.

Obviamente ressaltamos que esses resultados estão baseados nas percepções dos estudantes, colhidas através de questionário anônimo e, por isso, revelam um panorama local, datado, do momento da aplicação do questionário, ou seja, um recorte da realidade, podendo ser mais ou menos fidedigno a ela, de acordo com o contexto. Porém através disso e com base na análise das características positivas, conclui-se que alguns professores superaram os possíveis obstáculos epistemológicos encontrados no trabalho docente, sejam os do eixo emocional ou da linguagem, mas certamente, o fator formação, tem importante papel nessa superação.

Considerando esses dois primeiros eixos, as características destacadas e as respostas dos estudantes, temos:

\begin{tabular}{|c|l|l|}
\cline { 2 - 3 } \multicolumn{4}{c|}{} & \multicolumn{2}{c|}{ Características Positivas } \\
\hline \multirow{3}{*}{ Eixo Emocional } & Paciência & $\begin{array}{l}\text { Explica quantas vezes precisar, explica com } \\
\text { calma, é paciente. }\end{array}$ \\
\cline { 2 - 3 } & Dinamismo & $\begin{array}{l}\text { Dá atividades ótimas, dá experimentos, dá aulas } \\
\text { diferentes, utiliza materiais diferentes. }\end{array}$ \\
\cline { 2 - 3 } Eixo Comunicativo & Atenção & É legal, amigo, atencioso, simpática. \\
\hline \multirow{3}{*}{ Clareza } & Explica bem, sabe explicar. \\
\cline { 2 - 3 } & Escuta & Escuta quando falamos, \\
\cline { 2 - 3 } & Coerência & Respeita os alunos, mantém a disciplina, \\
\hline
\end{tabular}

Quadro 3 - Eixos 1 e 2 - Características Positivas 


\begin{tabular}{|c|l|l|}
\cline { 2 - 3 } \multicolumn{4}{c|}{ Eixo Emocional } & \multicolumn{2}{|c|}{ Características Negativas } \\
\cline { 2 - 3 } & Agressividade & $\begin{array}{l}\text { Fala só uma vez, depois perde a paciência, } \\
\text { corre com o conteúdo, }\end{array}$ \\
\cline { 2 - 3 } Eixo Comunicativo & $\begin{array}{l}\text { Nervosismo, fica bravo com os alunos, é } \\
\text { muito brava e nervosa. Chega na sala } \\
\text { neurótico e brigando. }\end{array}$ \\
\hline & Monotonia & $\begin{array}{l}\text { Aula muito cansativa e chata, a aula dá } \\
\text { sono. }\end{array}$ \\
\cline { 2 - 3 } & Lesorganização & $\begin{array}{l}\text { Escreve na lousa desorganizado, explica de } \\
\text { técnica } \\
\text { forma desorganizada e confusa. }\end{array}$ \\
\cline { 2 - 3 } & Grita & Fala um pouco alto, grita com os alunos \\
\hline
\end{tabular}

Quadro 4 - Eixos 1 e 2 - Características negativas

Destaca-se, também, que, apesar do caráter temporal das respostas dos estudantes, um recente levantamento realizado pela Divisão de Educação, do qual participaram 19.821, dos cerca de 22.000 estudantes matriculados no $2^{\circ}$ e $3^{\circ}$ ano do Ensino Médio, indica que as respostas dos estudantes continuam atuais, como pode ser percebido na imagem a seguir:

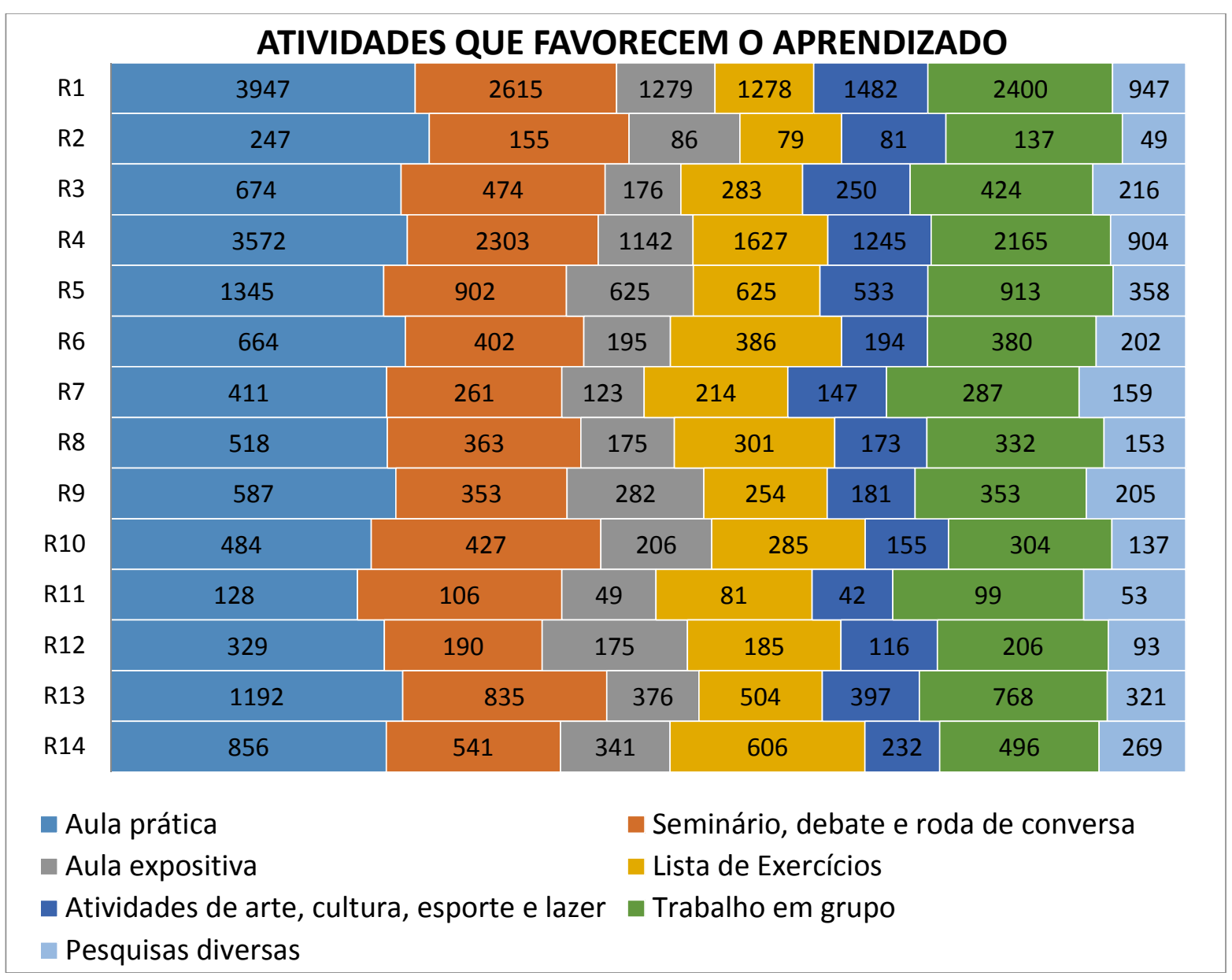

Figura 25 - Atividades que, para os estudantes, favorecem o aprendizado. Dados agrupados por Regiões Administrativas do Estado de São Paulo, excluindo-se a Região de Registro onde não há escolas SESI-SP. (Fonte: SESI-SP 2015) 
Assim o processo de elaboração conceitual por parte dos estudantes partiu de um processo cognitivo onde a valorização de alguns conceitos definiu sua relevância na pesquisa. Dessa forma, não cabe analisar somente a palavra em si, mas o seu significado. Partindo desse pressuposto, Vigotski destaca os diferentes tipos de organização lógica dos objetos submetidos ao significado da palavra. Ele valoriza as abstrações, análises e generalizações que a criança ${ }^{25}$ é capaz de articular, nos distintos momentos de seu desenvolvimento intelectual. Em sua perspectiva, o significado da palavra modifica-se durante o desenvolvimento da criança, modificando os modos pelos quais a realidade é refletida. Assim, a palavra reflete e generaliza a realidade e o significado é concebido como uma unidade de generalização e interação social (VIGOTSKI, 1987, p.21).

A fala da criança é tão importante quanto a ação para atingir um objetivo. As crianças não ficam simplesmente falando o que elas estão fazendo; sua fala e ação fazem parte de uma mesma função psicológica complexa, dirigida para a solução do problema em questão.

Ainda segundo esse autor a palavra tem peso, pois não define somente um objeto, mas o conceitua, e expressa também o conceito que o locutor faz daquele objeto. Por fim, podemos afirmar que ela expressa o significado que aquele objeto ou ato tem para o indivíduo, e por isso é mutável de acordo com a ampliação de seu universo epistemológico. Os processos que conduzem à elaboração conceitual são, portanto, sempre mediados pela palavra e, conquanto iniciem precocemente na infância, o que encontraremos então são apenas "formações intelectuais que realizam funções semelhantes àquelas dos conceitos verdadeiros" (VIGOTSKI, 1987, p.50).

Sendo assim, Vigotiski (1987) valida nosso pressuposto, mas também o data, pois, como apresentado anteriormente, o gráfico retrata um panorama local e datado. Temos assim a explicação do porquê, por exemplo, a palavra "Legal" aparece em destaque. Nesse contexto, dentro do referencial cultural do estudante, o bom professor é caracterizado e necessariamente tem que ser "Legal", independentemente do conceito do que é ou não legal, afastando o termo da denotação do dicionário.

Tem-se, ainda, a possibilidade de identificar um terceiro eixo e, talvez, o mais significativo, em torno do qual gravitam os outros dois: Formativo.

\footnotetext{
25 Entendido aqui na forma ampla indo da pré-infância até a adolescência, uma vez que a característica de significação pode ser estendida quiçá até a vida adulta.
} 
Nesse eixo encontramos respostas que revelam a forma, segundo o estudante, como o professor se relaciona com o conhecimento, com a mediação da aprendizagem e com as questões interpessoais no cotidiano escolar. Assim, temos:

Positivas: Conhecimento do conteúdo, explicação clara, aulas dinâmicas, trabalha os conteúdos em profundidade e mantém atenção dos estudantes (evitando indisciplina).

Negativas: Trabalha os conteúdos com muita pressa, é desorganizado e não respeita os estudantes, entre outros.

Considerando as características desse eixo e as respostas dos estudantes, a relação entre elas pode ser organizada da seguinte forma:

\begin{tabular}{|l|l|l|}
\cline { 2 - 3 } \multicolumn{1}{c|}{ Características Positivas } & \multicolumn{2}{c|}{ Eixo Formativo } \\
\cline { 2 - 3 } & Clareza & $\begin{array}{l}\text { Conhecimento aprofundado; tem amplo } \\
\text { conhecimento da área e com isso explica } \\
\text { melhor. }\end{array}$ \\
\cline { 2 - 3 } Características Negativas & $\begin{array}{l}\text { Sabe explicar; explica de um jeito que todo } \\
\text { mundo aprende. }\end{array}$ \\
\cline { 2 - 3 } & Ordem & $\begin{array}{l}\text { Sabe controlar a sala; mantém a sala em } \\
\text { ordem. }\end{array}$ \\
\cline { 2 - 3 } & Desorganização & $\begin{array}{l}\text { Muitos conteúdos em tempo curto, explica } \\
\text { rápido. }\end{array}$ \\
\cline { 2 - 3 } & $\begin{array}{l}\text { Escreve na lousa de forma desorganizada; } \\
\text { explica de forma desorganizada e confusa. }\end{array}$ \\
\cline { 2 - 3 } & Desrespeito & Fala um pouco alto; grita com os alunos. \\
\hline
\end{tabular}

Quadro 5 - Eixo 3 - Características positiva e negativas

Considerando as palavras e expressões que obtiveram bastante destaque na nuvem de palavras: conhecimento, clareza, explica bem, tira dúvidas, estas podem nos remeter à boa formação do professor e à valorização e reconhecimento do seu conhecimento técnico e aprofundado da especificidade da área, pelos estudantes, de forma que são tão presentes em suas falas.

Finalmente, é importante acrescentar que, os estudantes também se veem como elementos do processo, pois, em relação às características negativas, fazem bagunça ou conversam alto e, em relação às características positivas, demonstram interesse solicitando que a explicação seja retomada, demonstrando que não entenderam e estão interessados em aprender. Além disso, do total de estudantes que participaram da pesquisa, 72 deles indicaram não ter dificuldades ou que todos os professores são bons. 


\section{CONSIDERAÇÕES FINAIS}

No decorrer da pesquisa percebeu-se que o ensino oferecido pelo SESI-SP passou por diversas transformações ao longo de sua história vislumbrando a adequação às demandas da indústria e da sociedade de forma ampla, mas também na escala local. De forma gradual, rompeu, ainda que parcialmente, com sua "vocação inicial" de formar trabalhadores para a indústria, apesar de ainda manter salas de aula em fábricas e canteiros de obras. Além disso, no que se refere à Educação Básica regular, se percebe uma tendência ao retorno às origens, expressa na oferta pelo próprio SESI-SP de cursos técnicos de médio. Contudo, esse movimento também pode revelar conflitos internos, uma vez que a oferta desses cursos não é discutida e, como evidencia a consulta feita aos estudantes, a maior parte dos estudantes do Ensino Médio tem por objetivo ingressar em Cursos Superiores, visão compartilhada por parte dos técnicos da DEC.

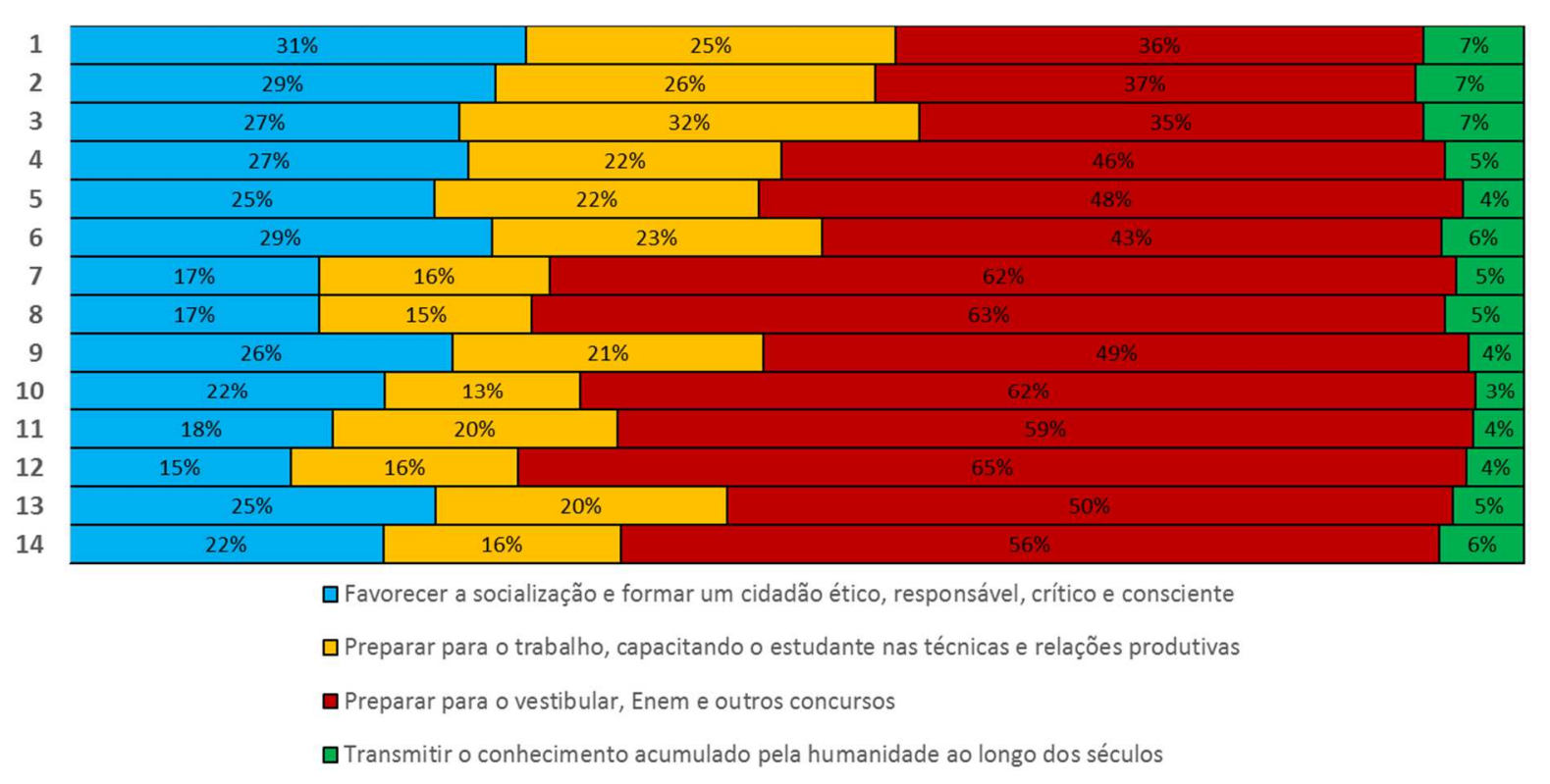

Figura 26 Importância do Ensino Médio para os estudantes do SESI-SP

Dados agrupados por Regiões Administrativas do Estado de São Paulo, excluindo-se a Região de Registro onde não há escolas SESI-SP. (Fonte: SESI-SP 2015)

Ressalta-se que essas mudanças vieram acompanhadas de maiores cobranças aos professores, não apenas em relação aos resultados apresentados pelos estudantes nas avaliações em larga escala como o SARESP, mas de maior tempo de permanência na escola e dedicação em sala de aula o que, para muitos, se torna uma tarefa árdua, cansativa. Afinal, são mais aulas a serem preparadas, avaliações a serem feitas, formulários a serem preenchidos. 
O impacto desse processo, como mostrado anteriormente, é percebido no desempenho dos estudantes que, apesar de considerarem os professores de Matemática e Língua Portuguesa como alguns dos melhores professores, não têm obtido progresso significativo nas avaliações em larga escala. Embora, no SARESP, parte significativa das escolas ter os estudantes com proficiência considerada adequada para nível de ensino/ série, isso não significa, de modo algum, que não seja necessário promover adequações para a melhoria da qualidade do ensino.

Além disso, as transformações na sociedade se estenderam, gerando novas demandas à escola e consequentemente, exigindo maiores esforços no processo de mediação da aprendizagem em sala de aula. E, ao menos através do que se pode perceber nas respostas dos estudantes, as ações de parte dos professores revela que lhes falta formação para atender essas novas necessidades. É importante notar, também, que essas respostas vêm, em parte, ao encontro das características apresentadas pelos Coordenadores Pedagógicos, mas principalmente quando dizem respeito ao bom professor. Eles enfatizam aspectos que reproduzem o discurso institucional, como planejamento, contextualização dos conteúdos e diversificação de atividades. Diferentemente dos estudantes, os Coordenadores Pedagógicos não destacam aspectos como a qualidade da explicação, a linguagem utilizada ou relacionamento interpessoal.

A relação entre os industriais e o Estado, aliada à carência ou ineficiência dos serviços públicos de educação que, inicialmente, possibilitou a criação do Serviço Social da Indústria, também contribuiu para a iniciativa da indústria de oferecer serviços educacionais por meio do Sistema de SESI-SP de Ensino.

Note-se ainda, que, para manter a imagem de instituição reconhecida pela qualidade dos serviços prestados, o SESI-SP se adaptou gradativamente às novas demandas da sociedade. Intensificou os investimentos na modernização tecnológica e arquitetônica de suas escolas, na prestação de novos serviços e presença nos meios de comunicação social com intensa campanha de marketing. Além disso, tem aproveitado a influência política do capital industrial e as oportunidades criadas pela legislação (onde também tem influência, seja participando de Conselhos em regional e nacional ou diretamente presente no poder executivo e legislativo) que regulamenta a educação no país para expandir seu sistema de ensino e, com isso, diversificar suas fontes de arrecadação e se estabelecer no mercado de prestação de serviços educacionais. Quanto a isso, também é possível inferir que a expansão do Sistema SESI-SP de Ensino confere à instituição e a seus dirigentes, maior visibilidade e destaque político, graças ao alcance da “marca” SESI, principalmente, no interior do estado de São Paulo. 
Mas, se o Sistema SESI-SP começa a ocupar um importante espaço na formação dos professores das redes públicas municipais, isso se deve, em parte, à deficiência das instituições públicas em atender suas próprias demandas; pode indicar uma crescente credibilidade desse sistema privado no que diz respeito à formação docente com vistas à melhora dos índices de aproveitamento dos estudantes em avaliações externas. Mas, por outro lado, também revela o engajamento político de lideranças locais em ações de propaganda e venda desse sistema de ensino.

No que tange à percepção dos estudantes, em relação ao trabalho dos professores, destaca-se a perspicácia de muitos deles em avaliar a partir de critérios bem elaborados e com preocupações que vão além das individuais, como ao dizer que o professor deveria

Seguir o ritmo da sala em geral e não de uma pessoa que domina o conteúdo, fazendo com que a sala a acompanhe (não é porque uma pessoa é boa e rápida que a sala toda tem que acompanhá-la, como professora ela deveria saber que ninguém é igual a ninguém e não tem a mesma facilidade no conteúdo).

Ou, ainda

Falta de profissionalismo em determinadas matérias, afeto por um grupo isolado de alunos que com isso afete o restante fazendo com que fiquem com dúvidas, falta de consideração, descumprimento de normas do SESI e possibilitando e influenciando alunos a infringi-las.

E, também

Todos os professores são ótimos, mas tem uma que a maioria não gosta. Ela é uma pessoa que não deixa agente falar na aula, mesmo você tendo dúvidas, ela não deixa ninguém, fazer nada. Ela faz algumas brincadeiras chatas, nos trata como se fôssemos crianças. É uma pessoa muito arrogante.

Uma avaliação de ordem mais pessoal, mas que merece ser destacada, pois aponta para a importância das relações interpessoais no processo de ensino e aprendizagem é a de um estudante do $9^{\circ}$ ano,

Na minha humilde opinião estou abrindo o meu coração, pois tenho muita dificuldade para me desabafar e venho através desse anonimato para falar que eu sinto sobre a professora de [...], ela não tem a paciência para nos explicar melhor a atividade. [...] já é difícil de aprender e ainda com uma professora que não é paciente é pior ainda... Muitas vezes ela me dá tiradas na sala de aula e também nos meus companheiros de classe. Eu tenho a plena certeza que essas tiradas que ela dá não são necessárias, assim como meus companheiros de classe também têm... E assim pegamos até bronca dela e dá vontade de não falar nada, pois ela já vai responder na arrogância e nos tirando...

Outros estudantes destacaram vários aspectos das ações de diferentes professores, que os incomodam: 
Alguns professores chegam à sala revoltados, achando que podem descontar a sua raiva na gente. Tem uns que nem sabem o que estão falando, já outros sabem, mas não sabem dar uma aula. Em certas aulas tem um/uma professor/a que entra na sala e fica falando, falando e contando da vida, apenas, e isso estressa, por que ao invés de ela explicar bem a matéria, ela fica falando coisas que eu não quero ouvir, como coisas que ocorrem na vida dela. Isso é muito chato, cansa. Tem um que entra na sala, e acha que sabe de tudo, e se achando, só porque tem as coisas, e acha que pode mandar na gente, descontando a sua raiva em nós. Se eles escolheram a profissão de ser professor, acho que eles deviam exercê-la bem, não ficarem reclamando da profissão e da vida, a cada 5 minutos de aula. Pô, já estou cansada de ficar ouvindo essas coisas, acho que isso que devia melhorar! Isso é minha opinião, e nada a mudará.

$\mathrm{E}$, finalmente

- Falta de vontade para explicar a matéria.

- Dificuldade de entender as necessidades dos alunos.

- Desperdício de tempo de aula causado por conversas desnecessárias.

- Falta de respeito com os alunos.

- Abuso de autoridade.

- Explica o conteúdo de forma razoável e confusa.

- Obrigar os alunos a fazer prova de recuperação sem saber sua nota anterior (não são todos).

- Falta de autoridade.

- Deixar pouco tempo para realização de atividades avaliativas.

- Grande parte da aula em frente a um computador, não dando a mínima para os alunos.

- Não vê o que acontece dentro de sua sala de aula, fazendo com que os alunos possam dormir, mexer no celular, colar, etc...

- Ameaçando [mandar para fora da sala] os alunos que estão conversando. Os mesmos continuam, e nada acontece.

- Não explicar o conteúdo de forma esclarecedora, e dar prova sobre a matéria "passada".

- Não tem certeza do que estão falando, deixando um ponto de interrogação em nossa cabeça.

Parte dessas características negativas pode ser atribuída ao ritmo intenso de trabalho dos professores, que ocupam a maior parte de seu tempo na escola, dando aulas, algumas vezes sem as condições organizacionais adequadas para refletir sobre o que está fazendo. Percebese que a modernização da estrutura das escolas da Rede SESI-SP de Ensino foi um passo nessa direção. Mas, para superar essa dificuldade, é preciso proporcionar maior tempo (com qualidade) para reflexões e contato dos professores com seus pares a fim de planejarem ações conjuntas, o que demanda vontade política e investimento. Além disso, como indicam (FULLAN, HARGREAVES, 1999), é necessário aproveitar o tempo e os espaços no interior 
da escola para potencializar as ações formativas da equipe docente, que o professor possa trabalhar em grupo, refletir e aprender com os outros. 


\section{REFERÊNCIAS}

ALVES, A. E. S. Trabalho docente e proletarização. Revista HISTEDBR On-Line, Campinas, n.36, p. 25-37, dez. 2009. Disponível em: https://www.fe.unicamp.br/revistas/ged/histedbr/article/view/3796/3212. Acesso em 15 Mar. 2015.

BECKER, F. A epistemologia do professor: O cotidiano da escola. Petrópolis: Vozes, 2002.

BRASIL. Decreto $\mathrm{n}^{\circ}$ 6.637, de 5 de novembro de 2008. Altera e acresce dispositivos ao Regulamento do Serviço Social da Indústria - SESI, aprovado pelo Decreto no 57.375 , de 2 de dezembro de 1965. Presidência da República, Brasília (DF), 5 nov. Disponível em:〈http://www.planalto.gov.br/ccivil_03/decreto/1950-1969/D57375.htm>. Acesso em: 14 dez. 2013.

Decreto $n^{\circ} 9.403$, de 25 de junho de 1946. Atribui à Confederação Nacional da Indústria o encargo de criar, organizar e dirigir o Serviço Social da Indústria, e dá outras providências. Disponível em: <http://www.planalto.gov.br/ccivil_03/decreto-lei/1937-1946/Del9403.htm> Acesso em: 12 abr. 2014

Decreto n. 91.542, de 19 de agosto de 1985. Institui o Programa Nacional do Livro Didático, dispõe sobre sua execução e dá outras providências. Diário Oficial da União, Brasília, 20 de agosto de 1985.

Decreto $\mathrm{n}^{\circ}$ 57.375, de 2 de dezembro de 1965. A prova o Regulamento do serviço Social da Indústria (SESI). Presidência da República, Brasília (DF), 2 dez. Disponível em:<http://www.planalto.gov.br/ccivil_03/decreto/1950-1969/D57375.htm>. Acesso em: 14 dez. 2013.

Ministério da Educação. Coordenação Geral de Operacionalização do Fundeb e de Acompanhamento e Distribuição do Salário-Educação. FUNDEB - Manual de orientação. Brasília, 2008.

CANO, W. Da Década de 1920 à de 1930: transição rumo à crise e à industrialização no Brasil. Revista de Políticas Públicas, v. 16, n. 1, 2012. pp. 79 - 90. Disponível em: $<$ http://www.periodicoseletronicos.ufma.br/index.php/rppublica/article/view/1179> Acesso em: 18 dez. 2013.

CARVALHO, M. A. M. de. A criação do SENAI no contexto da Era Vargas. Dissertação (Mestrado em História Econômica) - Faculdade de Filosofia, Letras e Ciências Humanas, Universidade de São Paulo, são Paulo, 2011. 
CUNHA, L. A. O ensino profissional na irradiação do industrialismo. 2 ed. - São Paulo: Editora UNESP; Brasília, DF, FLACSO, 2005.

O golpe na educação. - 11. Ed. - Rio de Janeiro: Jorge Zahar Ed., 2002.

DA SILVA MENGER, Ms A.; VALENÇA, Dr ${ }^{\mathrm{a}}$ V. L. C. A pedagogia histórico-crítica no contexto das teorias de educação. Poiésis-Revista do Programa de Pós-Graduação em Educação, v. 6, n. 10, p. 497-523, 2012. Disponível em: <http://www.portaldeperiodicos.unisul.br/index.php/Poiesis/article/view/1321/1072> Acesso em 13 de Abr. 2015.

DUARTE, N. Como pedagogias fazer "Aprender a Aprender" e algumas Ilusões da ASSIM Chamada Sociedade do Conhecimento. Rev. Bras. Educ., Rio de Janeiro, n. 18, p. 35-40, Dezembro de 2001. Disponível em: $<$ http://www.scielo.br/scielo.php?script=sci_arttext\&pid=S1413-

$24782001000300004 \& \operatorname{lng}=$ en\&nrm=iso $>$. Acesso em 20 de jun. 2015.

Vigotski e o "aprender a aprender": crítica às apropriações neoliberais e pós-modernas da teoria vigotskiana. Campinas: Autores Associados, 2000.

ENGUITA, M. F. A Face Oculta da Escola: educação e trabalho no capitalismo. Trad. Tomaz Tadeu da Silva. Porto Alegre: Artes Médicas, 1989.

FERREIRA, A. G. A. A difusão da Escola na Afirmação da Sociedade Burguesa. In: ALMEIDA, M. (org.) Política educacional e práticas pedagógicas: para além da mercadorização do conhecimento. $2^{a}$ ed. Cidade?:Alínea, 2010, p. 67 - 85. (Educação em debate).

FERREIRA, N. S. C. Formação continuada e gestão da educação no contexto da "cultura globalizada". IN: FERREIRA, N. S. C. (org). Formação continuada e gestão da educação. 2 ed. São Paulo: Cortez, 2006

FREITAS, M.T. A perspectiva sócio-histórica: uma visão humana da construção do conhecimento. In: ; SOUZA, S.J; KRAMER, S (orgs.). Ciências humanas e pesquisa: leitura de Mikhail Baktin. São Paulo: Cortez, 2003, p. 26-38.

FULLAN, M.; HARGREAVES, A. A escola como organização aprendente: buscando uma educação de qualidade. 2. ed. Porto Alegre: Artes Médicas, 2000.

FULLAN, M.; HARGREAVES, A. La Escuela que queremos. México: SEP/ Amorrortu, Biblioteca para la Actualización del Maestro, 1999.

FUSARI, J.C. Formação contínua de educadores na escola e em outras situações. In: BRUNO, E. B. G. et al. O coordenador pedagógico e a formação docente. São Paulo: Edições Loyola, v. 3, p. 17-24, 2000. 
GUMIERO, J. C. A industrialização no Brasil e as mudanças na parte diversificada do currículo do SESI/SP. 2002. 102 f. Dissertação (Mestrado em Educação) -Faculdade de Educação, Universidade São Marcos, São Paulo, 2002.

HARGREAVES, A. Os professores em tempos de mudança. O trabalho e a cultura dos professores na idade pós-moderna. Alfragide: Editora McGraw-Hill, 2001

LIBÂNEO, J. C.; PIMENTA, S. G., Formação dos profissionais da educação: visão crítica e perspectivas de mudança. In: PIMENTA, Selma Garrido (org.). Pedagogia e pedagogos: caminhos e perspectivas. São Paulo: Contexto, 2002, p. $11-57$.

LIMA, P. G.; DOS SANTOS, S. M.. O Coordenador Pedagógico na Educação Básica: Desafios e Perspectivas. Revista de, v. 2, n. 4, 2007. Disponível em: <http://coordenacaoescolagestores.mec.gov.br/ufpb/file.php/1/coord_ped/sala_3/arquivos/o_coor d_pedag_na_educ_basica_desafios_e_perspectivas.pdf > Acesso em 30 Jun. 2015).

MIRANDA, M. E. A Atualidade de Pierre Monbeig e o Direito de Aprender Geografia. Revista do Departamento de Geografia, [S.1.], p. 52-67, dez. 2012. ISSN 2236-2878. Disponível em: <http://www.revistas.usp.br/rdg/article/view/53842>. Acesso em: 21 Mar. 2014.

MONTEIRO, A. M. F. C. Professores: Entre Saberes e Práticas. Educação \& Sociedade, ano XXII, $\quad \mathrm{n}^{\mathrm{o}}$ 74, pp. $131 \quad$ - 142, Abril, 2001. Disponível em:<http://www.scielo.br/pdf/es/v22n74/a08v2274.pdf>. Acesso em: 03 Mar. 2013.

MOURA, D. H. Educação Básica e educação profissional e tecnológica: dualidade histórica e perspectivas de integração. IN: Anais da $30^{\mathrm{a}}$ Reunião Anual da ANPED. Caxambu/MG: ANPED, 2007.2 Disponível em: <http://www2.ifrn.edu.br/ojs/index.php/HOLOS/article/viewArticle/11> Acesso em 22 Abr. 2015.

NAGEL, L. H. "O aqui e o agora", sem "o ontem e o amanhã", nas políticas da educação. In: NOGUEIRA, Francis Mary Guimarães; RIZOTTO, M. L. F. (Org.). Estado e Políticas Sociais: Brasil - Paraná. 1 ed. Cascavel: EDUNIOESTE, 2003, p. 29-40.

NOMERIANO, A. O modelo de competências e a educação do trabalhador: uma análise à luz da ontologia marxiana (Dissertação de Mestrado). Faculdade de Educação da Universidade Federal de Alagoas, 2005.

NOSELLA, P.; BUFFA, E. Instituições Escolares: por que e como pesquisar. $2^{\mathrm{a}}$ ed., Campinas: Alínea, 2013.

NUNES, C. M. F. Saberes Docentes e formação de professores: um breve panorama da pesquisa brasileira.Educação \& Sociedade, ano XXII, n ${ }^{\circ}$ 74, pp. 27-42, Abril, 2001. Disponível em:<http://www.scielo.br/pdf/es/v22n74/a03v2274.pdf> Acesso em: 25 fev. 2012. 
OLIVEIRA, D. A.; FERREIRA, E. B. Políticas sociais e democratização da educação: novas fronteiras entre público e privado. In: AZEVEDO, M. L. N. (org). Políticas públicas e educação: debates contemporâneos. Maringá: Eduem, 2008 p. 23 - 45.

OLIVEIRA, D. M.A Formação de Professores na Lei 9394/96-Um estudo comparativo das diretrizes estabelecidas para a formação de professores de Educação Infantil e das séries iniciais do Ensino Fundamental nos anos 70 e nos anos 90. Rio de Janeiro, 1998. In: Anais do V Congresso de Ciências Humanas, Letras e Artes. Ouro Preto. 2001. p. 156-169. Disponível em; http://www.ichs.ufop.br/conifes/anais/EDU/edu1603.htm Acesso em: 22 de Jun. 2014.

OLIVEIRA, R. P. de. A transformação da educação em mercadoria no Brasil. Educação e Sociedade, Campinas, v. 30, n. 108, p. 739-760, out. 2009

PATARRA, N.L. (2003) "Movimentos Migratórios no Brasil: tempos e espaços" Textos para discussão Escola Nacional de Estatística Número 7. ENCE, Rio de Janeiro, 2007

PERRENOUD, Ph. (1999). Avaliação - da Excelência à Regulação das Aprendizagens. Porto Alegre : Artmed Editora (trad. en portugais de L'évaluation des élèves. De la fabrication de l'excellence à la régulation des apprentissages. Bruxelles : De Boeck, 1998).

Ph. Construir as Competências desde a Escola. Porto Alegre :Artmed Editora (trad. en portugais de Construire des compétences dès l'école. Paris: ESF, 1997, 2 éd. 1998).

Ph. (2001). Porquê construir competências a partir da escola? Desenvolvimento da autonomia e luta contra as desigualdades. Porto: ASA Editores.

PIAGET, J. "A Situação das Ciências do Homem no Sistema das Ciências (Volume1)." Tradução de Isabel Cardigos dos Reis. Lisboa: Livraria Bertrand, 1976.

PY, C. A. de A. Controladoria Geral da União - Relatório de Avaliação da Execução de Programas de Governo N 13 SENAI - Desenvolvimento Da Educação Profissional E Tecnológica. Brasília, 2012.

REPA, M. H. Escola e mobilidade social: um estudo sobre os egressos do SESI Vila Cisper. 2008. 94 p. Dissertação. (Mestrado em Educação: História, Política e Sociedade) PUC-SP, são Paulo, 2008.

ROMERO, A. P. H.; NOMA, A. K. "Novos" movimentos da sociedade civil, no final do século XX: o terceiro setor na educação. In: AZEVEDO, M. L. N. (org). Políticas públicas e educação: debates contemporâneos. Maringá: Eduem, 2008, p. 81 - 105.

SANTOS, H. Formação dos profissionais da educação profissional. In: MEC. Educação Profissional: concepções, experiências, problemas e propostas - Anais. Brasília: MEC, 2003.

SÃO PAULO. Informações Básicas - Programa Ensino Integral - Escola de tempo integral, São Paulo, 2014. Disponível em: 
<integralttp://www.educacao.sp.gov.br/a2sitebox/arquivos/documentos/727.pdf> Acesso em 23 de Jun. 2015.

SAVIANI, D. Educação e políticas especiais. INEP. Políticas públicas \& educação. Brasília, DF: INEP; São Paulo: Fundação Carlos Chagas, Campinas: UNICAMP, 1987.

Escola e Democracia. 34. ed. rev. Campinas, Autores Associados, 2001. (Col. Polêmicas do Nosso Tempo; vol. 5). 94 p.

Sistemas de ensino e planos de educação: o âmbito dos municípios. Educação \& Sociedade, v. 20, n. 69, p. 119-136, 1999. Disponível em: <http://www.scielo.br/pdf/es/v20n69/a06v2069> Acesso em 13 de Mai. 2015.

SCHIAVONI, A.; DE CÁSSIA MARTINELLI, S. Percepção de alunos sobre as expectativas do professor acerca do seu desempenho: um estudo comparativo entre alunos com e sem dificuldades de aprendizagem. Interação em Psicologia (Qualis/CAPES: A2), v. 9, n. 2, 2005. Disponível em <http://ojs.c3sl.ufpr.br/ojs/index.php/psicologia/article/viewArticle/4785>. Acesso em: 13 Ago. 2014.

SESI-SP. Geografia: Ensino Fundamental $6^{\circ}$ ano. SESI-SP; 1 ed. São Paulo: SESI, 2000. (Movimento do Aprender)

Geografia: Ensino Médio $1^{\circ}$ ano. SESI-SP; 1 ed. São Paulo: SESI, 2012. (Movimento do Aprender)

- Investimento na modernização da estrutura educacional. Disponível em: http://www.sesisp.org.br/educacao/noticias/investimento-na-modernizacao-da-estruturaeducacional. Acesso em: 21 de Jun. 2015

Pesquisa Material didático Ensino Médio - 2013. São Paulo, 2013. (Relatório)

Referenciais Curriculares da Rede Escolar SESI-SP. São Paulo: SESI, 2003. Disponível em: http://www.youblisher.com/p/869829-REFERENCIAIS-CURRICULARES/ Acesso em: 21de Fev. 2014.

Referenciais Curriculares da Rede Escolar SESI-SP. São Paulo: SESI, 2015. (Documento de circulação interna). Localização: Arquivos da Gerência de Currículos e Programas.

_. Regimento Comum da Rede Escolar SESI-SP. São Paulo, 2007.

_. Regimento Comum da Rede Escolar SESI-SP. São Paulo, 2010.

SESI Jornal, ANO I - 31 de março de 1949, p. 1 
SILVA JR, N. F. O papel do Coordenador Pedagógico na formação dos professores de Geografia na Rede Escolar SESI-SP. 64 p. Monografia (Especialização em Gestão Escolar e Coordenação Pedagógica), AVM Faculdade Integrada, Rio de Janeiro, 2012.

SESI-SP. Percepção dos professores de Geografia do Ensino Fundamental sobre o material didático impresso da rede escolar SESI-SP. 12 p., São Paulo, 2013. (Relatório). Localizado em: Arquivos da Gerência de Educação Básica.

SILVA, T. T. da \& GENTILI, P. A. A. (Orgs). Neoliberalismo, qualidade total e educação. Petrópolis, RJ: Editora Vozes, 1994.

TEIXEIRA, A. Educação não é privilégio. Revista Brasileira de Estudos Pedagógicos. Brasília, v.70, n.166, 1989. p.435-462 2. Ed. Disponível em: http://www.bvanisioteixeira.ufba.br/artigos/educacao8.html. Acesso em: 12 Mai. 2015.

VELLOSO, J. Política educacional e recursos para o ensino: o salário-educação e a Universidade Federal. Cadernos de Pesquisa, São Paulo, n. 61, p. 3-29, maio1987. Disponível em: 〈http://www.fcc.org.br/pesquisa/publicacoes/cp/arquivos/715.pdf> Acesso em: 15 Dez. 2013.

VIEIRA, C. T.; VIEIRA, R. M Construção de práticas didático-pedagógicas com orientação CTS: impacto de um programa de formação continuada de professores de Ciências do ensino básico. Ciência \& Educação, v. 11, n. 2, p. 191-211, 2015.

VIGOTSKI, L.S. Pensamento e Linguagem. São Paulo: Martins Fontes, 1987, p. 5.

WEINSTEIN, B. (Re)formulação da classe trabalhadora no Brasil (1920-1964). São Paulo: Cortez/CDAPH-IFAN/ Universidade São Francisco, 2000. 


\begin{abstract}
APÊNDICES
APÊNDICE 1 Pesquisa de opinião: Olhares sobre a prática docente na rede escolar SESI SP

Caro estudante, muito se diz sobre a forma como os professores trabalham e o que ensinam. São feitas avaliações para quantificar e qualificar o resultado desse trabalho, mas raramente se houve a voz dos principais interessados desse processo: o estudante. Pois é justamente esse, o objetivo dessa pesquisa: Saber o que os alunos pensam sobre o que é ser um bom professor e levantar informações que contribuam para o mapeamento das boas práticas docentes na Rede Escolar SESI-SP .
\end{abstract}

Sua opinião é muito importante! Basta responder as 06 (seis) questões a seguir e enviar.

Obrigado por participar.

01 - Em qual Centro Educacional você estuda?

Após responder, role a página até o final para continuar.

Sobre sua instrução

02 - Este ano você está cursando o *

6ㅇ Ano do Ensino Fundamental.

70 Ano do Ensino Fundamental.

8 Ano do Ensino Fundamental.

9o Ano do Ensino Fundamental.

1ํ Ano do Ensino Médio.

2ำ Ano do Ensino Médio.

3을 Ano do Ensino Médio. 
Escolhendo um professor

Quando dizemos professor, estamos nos referindo tanto a professores quanto a professoras.

3 - Entre os professores que deram aulas para você neste primeiro semestre de 2013 (no SESI), você considera melhor aquele que dá aulas de

04 - Indique três características desse professor que levaram você a indicá-lo como o melhor Quando dizemos professor, estamos nos referindo tanto a professores quanto a professoras.

Primeira característica:

Segunda característica:

Terceira característica:

05 - Avalie os materiais didáticos utilizados pelo professor que você escolheu como sendo o melhor entre aqueles que dão aulas para você

Avalie de 1 a 10, onde 1 significa que o material é muito ruim ou péssimo e 10 significa que o material é ótimo.

Livros didáticos

a) Considere apenas o livro "Movimento do Aprender"

$\begin{array}{llllllllll}1 & 2 & 3 & 4 & 5 & 6 & 7 & 8 & 9 & 10\end{array}$

Muito ruim ou

Ótimo

péssimo

b) Considere apenas o livro "Muitos textos... tantas palavras".

$$
\begin{array}{llllllllll}
1 & 2 & 3 & 4 & 5 & 6 & 7 & 8 & 9 & 10
\end{array}
$$

Muito ruim ou

Ótimo

péssimo

Outros materiais didáticos

Considere todos os outros materiais utilizados ou sugeridos pelo professor (textos, vídeos, livros, jogos, imagens, problemas, etc.) 
$\begin{array}{llllllllll}1 & 2 & 3 & 4 & 5 & 6 & 7 & 8 & 9 & 10\end{array}$

Muito ruim ou

Ótimo

péssimo

06 - Em relação às ações de seus professores, indique uma que dificulta sua aprendizagem.

Considere ações de modo geral, sem indicar nomes de professores

Característica:

Obrigado! Confirme suas respostas clicando enviar. 
APÊNDICE 2 Carta aos Administradores dos Centros Educacionais da Rede Escolar SESI-SP

Aos Srs.

Administradores dos Centros Educacionais da Rede Escolar SESI-SP

Aos Cuidados

Professora Anaide Trevizan

Gerência de Currículos e Programas

Anaide, bom dia.

Primeiramente, gostaria de agradecer sua atenção em relação à minha solicitação de continuar minha pesquisa junto aos alunos da Rede Escolar SESI-SP.

Quando fui aprovado no programa de mestrado em Geografia Humana da USP, solicitei, por escrito, autorização do diretor da Divisão de Educação, Prof. Fernando Antonio Carvalho de Souza para executar a parte empírica de meu projeto nas escolas do SESI, a qual foi concedida. A primeira etapa deste trabalho consiste em questionar os estudantes, em linhas gerais, a respeito das boas práticas de seus professores para, daí, identificar uma amostra de professores a serem entrevistados.

Entretanto, logo após termos trocado e-mails para tratar dos encaminhamentos e dirimir as dúvidas a respeito desta investigação, tive problemas de saúde e passei a concentrar meus esforços na pesquisa bibliográfica. Além disso, devido às inúmeras demandas da GCP e das escolas, naquele momento, julguei oportuno adiar o envio do questionário aos estudantes.

Solicito, assim, que este e-mail seja encaminhado às Administradoras dos Centros Educacionais da Rede Escolar SESI-SP, tornando possível a consulta aos estudantes, o que será feito via questionário no Google Docs. Solicito, ainda que seja passado aos alunos do 6으 ano Ensino Fundamental ao 3 ำ ano do Ensino Médio, o link goo.gl/akS5nJ o qual estará disponível para acesso até o dia 27 de setembro de 2013.

Neste questionário é solicitado que os estudantes respondam seis questões:

01 - Em qual Centro Educacional você estuda? (são indicadas as escolas para o aluno assinalar uma).

02 - Qual ano você está cursando? (do 6 ano do Ensino Fundamental ao 3 do Ensino Médio). 
03 - Entre os professores que deram aulas para você neste primeiro semestre de 2013 (no SESI), você considera melhor aquele que dá aulas de...(São indicadas todas as disciplinas).

04 - Indique três características desse professor que levaram você a indicá-lo como o melhor.

05 - Avalie os materiais didáticos utilizados pelo professor que você escolheu como sendo o melhor entre aqueles que dão aulas para você (livros e outros materiais).

06 - Em relação às ações de seus professores, indique uma que dificulta sua aprendizagem.

Ressalto que não há nenhuma necessidade de identificação por parte dos alunos, garantindo assim, seu anonimato e que, quando a amostra de professores estiver definida, me comprometo, por questões acadêmicas e éticas, a tomar todas as medidas cabíveis para garantir o anonimato das partes envolvidas ou os direitos para utilização de nomes e/ ou imagens.

\section{Orientação aos estudantes:}

1. Acessar o link goo.gl/akS5nJ

2. Responder as questões objetivas e discursivas sem se identificar

3. Não mencionar o nome de nenhum professor

4. Se, durante o preenchimento, quiser mudar alguma resposta, clique no botão "voltar" de seu navegador

5. Depois da questão $\mathrm{n}^{\circ}$ 6, clique em submit (enviar) para confirmar suas respostas

6. Responda o questionário apenas uma vez

a. Obs.: Esse questionário faz parte de uma pesquisa em nível de mestrado sobre o ensino na Rede Escolar SESI-SP . Obrigado por participar. Os resultados serão socializados oportunamente.

Atenciosamente,

Nabor Francisco da Silva Junior

FFLCH - USP

SESI-SP

São Paulo, 27 de agosto de 2013 


\section{APÊNDICE 3 TERMO DE CONSENTIMENTO LIVRE E ESCLARECIDO (Transcrição da solicitação)}

\section{Ao Professor}

Fernando Antonio Carvalho de Souza

Diretor da Divisão de Educação do SESI-SP

Eu, Nabor Francisco da Silva Junior, ingressei como aluno regular do Mestrado em Geografia Humana no Programa de Pós-Graduação da Universidade de São Paulo sob orientação da Profa. Dra. Maria Eliza Miranda.

Em meu projeto de pesquisa, de caráter predominantemente qualitativo, me proponho a investigar e analisar as práticas discursivas dos professores de Geografia considerados por seus alunos, como sendo os melhores.

Em razão disso, solicito autorização para a utilização de dados dos seguintes documentos: Referenciais Curriculares da rede escolar SESI-SP, Regimento Comum da rede escolar SESI-SP, relatórios do SARESP (Sistema de Avaliação de Rendimento Escolar do Estado de São Paulo) e dados do ENEM.

Como parte dessa investigação será feita de forma empírica, solicito autorização para enviar um questionário a ser respondido (pelo Google Disco) pelos alunos do 6ㅇ ao 9o ano do Ensino Fundamental e pelos alunos do Ensino Médio, assim como para entrevistar os professores que forem considerados os melhores de suas escolas, "eleitos" pelos alunos.

Esclareço que as informações colhidas serão utilizadas somente no campo acadêmico, garantindo o anonimato das escolas e dos sujeitos participantes.

Esperando contar com a sua colaboração e, antecipadamente, agradeço e colocando-me à disposição para quaisquer esclarecimentos a respeito desse trabalho.

Atenciosamente,

Nabor Francisco da Silva Junior

Autorização:

$\mathrm{Eu}$ diretor da Divisão de Educação do SESI-

SP autorizo a utilização dos dados dos documentos acima citados na pesquisa de Mestrado em Geografia Humana do aluno Nabor Francisco da Silva Junior. 


\section{ANEXOS}

ANEXO 1 Pauta de Encontro de Formação de Professores do Ensino Fundamental II

Divisão de Educação Básica

Gerência de Educação Básica

2 ENCONTRO DE FORMAÇÃO CONTINUADA DE PROFESSORES DO

ENSINO FUNDAMENTAL DE GEOGRAFIA Pauta do Analista

2008

"O essencial não é vencer, mas competir com lealdade, cavalheirismo e valor" Coubertin - 1894.

Leitura do texto: Estatuto do Homem - Thiago de Mello

Contribuição para o Projeto Muitos Textos Tantas Palavras....

\section{Objetivos do Encontro}

Discutir o trabalho com as expectativas de ensino e aprendizagem dos ciclos III e IV que possibilitem desenvolver atividades relacionadas aos Jogos Olímpicos.

Promover momentos de discussão e elaboração de atividades.

Devolutiva da Avaliação do 10 Encontro 2008: Apresentação de gráfico - geral e por pólo

\section{Jogos Olímpicos na Escola:}

Como os Jogos Olímpicos são trabalhados normalmente?

Registrar a fala dos professores

\section{Discussão das Expectativas selecionadas}

Inicialmente os professores serão organizados em grupos de 3 ou 4 componentes cada, onde deverão socializar as expectativas selecionadas previamente, discutindo os critérios de escolha e selecionar. O grupo deverá optar por duas expectativas do ciclo III e duas do ciclo IV e socializar (inclusive os analistas).

Cada grupo socializará sua opção e os professores deverão optar por duas ou três expectativas de cada ciclo entre as apresentadas.

Em seguida o grupo fará uma relação de conteúdos, habilidades e competências contempladas nas expectativas, bem como os recursos que poderão ser utilizados no desenvolvimento do trabalho com as mesmas. (neste momento é importante questionar qual a relação dos recursos com os conteúdose as expectativas de ensino e aprendizagem)

\section{Elaboração do Plano de Aula / Atividade}

De volta aos pequenos grupos e com as expectativas escolhidas, considerando as discussões anteriores, cada grupo deverá elaborar um plano de aula / atividade. (destacar a importância da aplicação dos procedimentos metodológicos). Cada grupo poderá fazer para um ciclo ou ano do ciclo. Após a elaboração, os grupos farão a socialização de suas produções, possibilitando uma análise e discussão por todos os presentes.

Atenção para os procedimentos metodológicos 


\section{7- Apresentação do modelo organizativo}

Depois da discussão do grupo, o analista apresentará aos professores um modelo organizativo elaborado pela equipe.

8- Levantar e registrar combinados para o 3 encontro de formação 2008.

Aplicação do Modelo Organizativo e da atividade elaborado no encontro.

Escolher um professor para aplicar o MO e a atividade elaborada no encontro.

Socializar essas experiências no 3o Encontro de 2008.

Próximo encontro será discutido:

África no Ensino de Geografia

Lei no. 10639 de 09/01/2003

\section{9- Avaliação do Encontro}

ANEXO 2 Pauta de encontro de Formação de Professores do Ensino Médio

Apresentação

Apresentação do grupo de professores e analistas.

Logo na entrada os professores receberão uma "ficha" que determinará o grupo no qual ele trabalhará. O último professor a integrar o grupo será o orador!

Nos grupos os professores deverão se apresentar e expressar suas expectativas em relação ao encontro; Considerando essas expectativas os grupos confeccionarão um painel com recortes de revistas que será apresentado em seguida;

O orador deverá apresentar os integrantes do grupo e o painel.

Objetivos do encontro

Proporcionar momentos de vivência e reflexão sobre a prática docente;

Refletir sobre as expectativas de ensino e aprendizagem considerando o currículo para os primeiro e segundo anos do E.M. da rede SESI de ensino;

Oportunizar reflexões acerca da importância e operacionalização da avaliação em sua dimensão formativa.

Resgate do primeiro encontro de 2008

Aproveitaremos este momento para "rever" alguns itens discutidos no primeiro encontro de 2008:

Gestão do tempo em sala de aula;

Autonomia dos alunos;

Pesquisa e estudo do meio;

Lição de casa.

Socialização dos Modelos Organizativos "aplicados" pelos professores

Os professores que ficaram incumbidos de aplicar o modelo organizativo discutido no primeiro encontro de 2008 socializarão sua experiência apresentando materiais produzidos pelos alunos. Os demais professores acompanharão a apresentação utilizando-se de uma pauta de observação elaborada pela equipe de analistas.

Questões preliminares: Avaliação e Currículo no Ensino Médio - Avanços e Perspectivas. 
Se avaliar pressupõe julgar, o que deve ser avaliado em Geografia no Ensino Médio? De que forma isso pode ser feito?

O que deve ser considerado para a seleção de conteúdos de Geografia no Ensino Médio?

Em relação à prática docente no Ensino Médio do SESI aponte o que considera como principais avanços e desafios.

Os professores serão divididos em grupos e farão um rodízio pelas questões respondendo-as. Quando todos os grupos tiverem passado pelas questões, as respostas serão socializadas e discutidas.

Estudo dos itens do quadro de conteúdos/habilidades/competências

Faremos a ligação desse estudo com as questões respondidas anteriormente de maneira a contribuir com os professores para o avanço na compreensão da proposta pedagógica da rede e concepção da área de Geografia.

Além disso, pediremos que analisem o que deve ser avaliado em uma dessas "expectativas".

Questões didáticas da Geografia na Rede SESI de Ensino

Proporemos uma discussão voltada para a prática docente partindo das "expectativas" acima. Destacaremos que é preciso perguntar-se:

De qual saber geográfico seus alunos são portadores quando iniciam sua escolarização geográfica e quando são apresentados a um determinado tema?

Como são selecionados os conteúdos para ampliar esses sabares? Que critérios você utiliza?

Destacar a importância da interdisciplinaridade e do estudo do meio como "ferramentas" do trabalho em Geografia.

Transparências sobre o tema

Avaliação: A aula revelada.

Seleção no grupo de uma avaliação do professor para socialização.

Considerando este instrumento avaliativo que hipóteses podem se levantadas a respeito das aulas do professor e das possiveis "expectativas" que orientaram seu trabalho?

Que habilidades estão sendo exigidas dos alunos para responder às questões?

Em qual "dimensão" da avaliação este instrumento se enquadra: diagnóstica, formativa ou classificatória?

Após a socialização pelos professores proporemos uma discussão sobre Avaliação Formativa fundamentada em Philippe Perrenoud e Ratz relacionando com os instrumentos selecionados pelos professores.

Após essa discussão enfatizaremos a necessidade de observar os alunos em ação e proporemos a elaboração de uma pauta de observação dos alunos considerando as expectativas discutidas no encontro.

Avaliação do encontro

Bibliografia 
ABREU, João Francisco de. \& FILHO, Oswaldo Amorim. Imagem, Representação e Geopolítica. In Elementos de Epistemologia da Geografia Contemporânea.Editora UFPR - Curitiba - PR 2004.

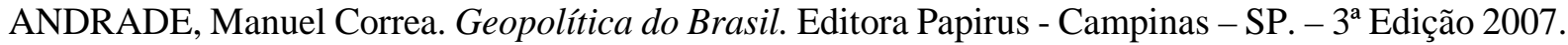
QUAINI, Massimo. Marxismo e Geografia. Editora Paz e Terra - Rio de Janeiro - RJ. $3^{\text {a }}$ Edição - 2002. SANTOS, Milton. Da Totalidade ao Lugar. EDUSP - São Paulo - SP - Edição 2005.

KIMURA, Shoko. Geografia no Ensino Básico - Questões e Propostas. Editora Contexto. São Paulo SP - 2008 . 
ANEXO 3 RE- 02/2006 - Implanta o Ensino Fundamental de 9 anos, o Ensino Fundamental em tempo integra, o Ensino Médio Regular e o Ensino Médio Articulado com o SENAI

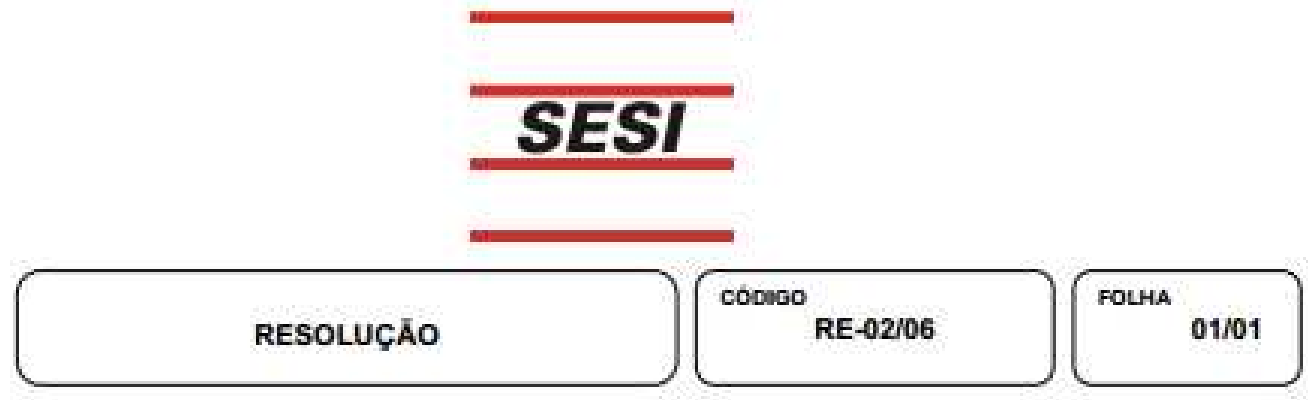

o Diretor Regional e o Superintendente Operacional do Departamento Regional de São Paulo, do Serviço Social da Indústria - SESI, Paulo Skaf e Luis Carlos de Souza Vieira, no uso de suas atribuiçoes regulamentares, e atendendo as determinações emanadas do Conselho Regional da Entidade, e

Considerando:

a) o quanto disposto na Lei Federal n' 11.274 , de 6/2/2006, que determina que os Municipios, os Estados e o Distrito Federal devem implementar o Ensino Fundamental de 9 (nove) anos;

b) o quanto disposto no Decteto $n^{\circ} 5.154$, de 23/7/2004, que regulamenta o $\$ 2^{\circ}$ do artigo 36 e os artigos 39 a 41 da Lei $n^{\circ} 9.394 / 1996$ e

c) as deliberações adotadas pelo Conselho Regional do SESI-SP, em especial o quanto decidido, por unanimidade dos votos de seus membros, na $8^{2}$ Reunião Ordinária do exercicio de 2006 , realizada a $2 \mathrm{~L} / 9 / 2006$,

\section{RESOLVEM}

1) Implantar, a partir do ano letivo de $200 \%$ :

a) o Ensino Fundamental de 9 (nove) anos, destinado aos alunos que ingressarem no Ciclo I Básico (1* ano) em todas as Unidades Escolares do SESI-SP;

b) o Ensino Fundamental em periodo integral para os alunos que ingressarem no Cíclo 1 -Básico $\left(1^{\circ}\right.$ ano) nas Unidades Escolares localizadas nos Centros de Atividades - CATs;

c) o Ensino Médio nas Unidades Escolares localizadas nos Centros de Atividades - CATs;

d) o Ensino Médio articulado, de forma concomitante, com a Educação Profissional Técrica de nivel médio, ofertada pela rede de Unädades Escolares do SENAI-SP.

2) Instituir, para o cumprimento do item 1, a cohrança, a partir do ano letivo de 2007 , de Taxa Escolar para os alunos matriculados na Educação Infantil e no Ensino Fundamental e de Mensalidade para aqueles matriculados no Ensino Médio.

3) A presente Resolução, que será regulamentada por meio de Instrup̧óes de Serviço da Superintendincia Operacional, entra em vigor nesta data, revogando-se as disposiçôes em contrírio.

São Paulo, 6 de outubro de 2006.

\author{
Paulo Skaf \\ Diretor Regional
}

Luis Carlos de Souza Vieira Superintendente Operacional

EMENTA Implanta o Ensino Fundamental de 9 anos - periodos parcial e integral - e o Ensino Médio no SESI-SP e institui Taxa Escolar e Mensalidade. 
ANEXO 4 - RE - 29/12 Altera a Estrutura Organizacional da Diretoria de Operações do SESI-SP
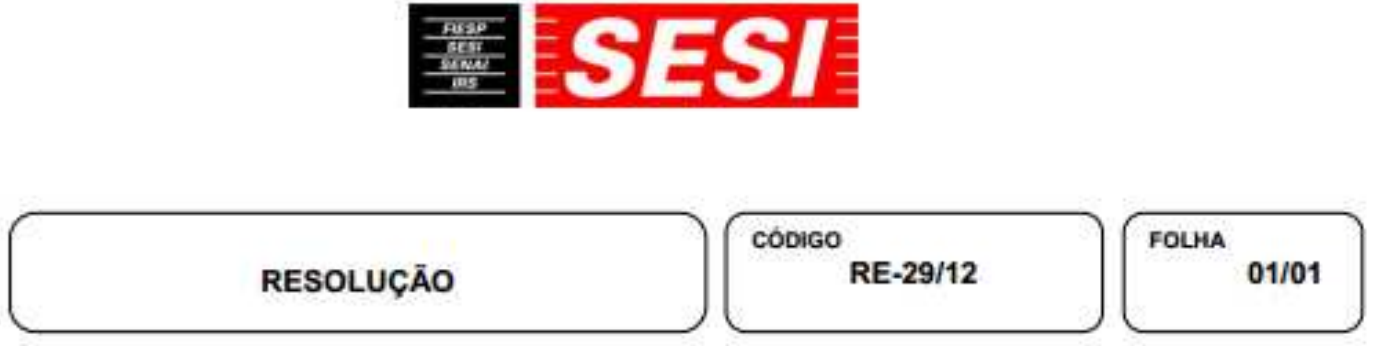

O Superintendente do Departamento Regional de Săo Paulo, do Serviço Social da Indústria - SESI, Walter Vicioni Gonçalves, consoante delegaç̧̋̉o da Diretoria Regional da Entidade, e

Considerando:

- a revisào da Proposta Curricular da Educaçầo Básica, de modo a promover a transposiçâo da organizaçăo dos componentes curriculares em âreas de conhecimento;

- a consolidaçầo da Proposta Curricular da Educaçâo Profissional Téenica de Nivel Médio, de modo a fortalecer a participação das Divisóes-fim, bem como, a ampliaçăo da oferta de vagas e novos cursos;

- o favorecimento da gestào autônoma das Unidades Escolares;

- a necessidade de rever a estrutura organizacional da Divisão de modo a:

- reposicionar o papel da Supervisào de Ensino Delegaida;

- reorganizar a Gerência de Curriculos e Programas;

- executar projetos formativos e monitoramento in loco para verificaçào do desenvolvimento da Proposta Curricular e cumprimento dos dispositivos legais;

- possibilitar a ampliaçåo da oferta e acompanhamento do Sistema SESI-SP de Ensino nos municipios;

- fortalecer a integraçăo das açōes da Divisão de Educação e Diretorias dos Centros de Atividades,

\section{RESOLVE}

1. Alterar, com efeito retroativo a $20 / 8 / 12$, a estrutura organizacional da Divisåo de Educaçăo da Diretoria de Operaçōes do SESI-SP, que passa a contar com:

- Assessoria

- Gerência de Programas Educacionais Especiais

- Gerência de Avaliaçâo Educacional

- Geréncia de Curriculos e Programas

- Gerência de Organização Escolar

- Supervisăto Estratégica de Atendimento.

3. Definir as atribuiçōes da Divisł̋ de Educaçẫo e dos órgâos a ela vinculados, conforme Anexo I, parte integrante deste Instrumento.

4. Estabelecer o organograma da Divisào de Educaçầ, conforme Ancxo II, parte integrante deste Instrumento.

5. Esta Resoluçào entra em vigor nesta data, revogando-se as disposiçòes em contrário, em especial a RE-11/10, de $22 / 7 / 0$.

Sało Paulo, 28 de agosto de 2012.

Walter Vicioni Gonçalves Superintendente

EMENTA: Define a estrutura organizacional da Divisåo de Educaçâo da Diretoria de Operaçōes do SESI-SP. 


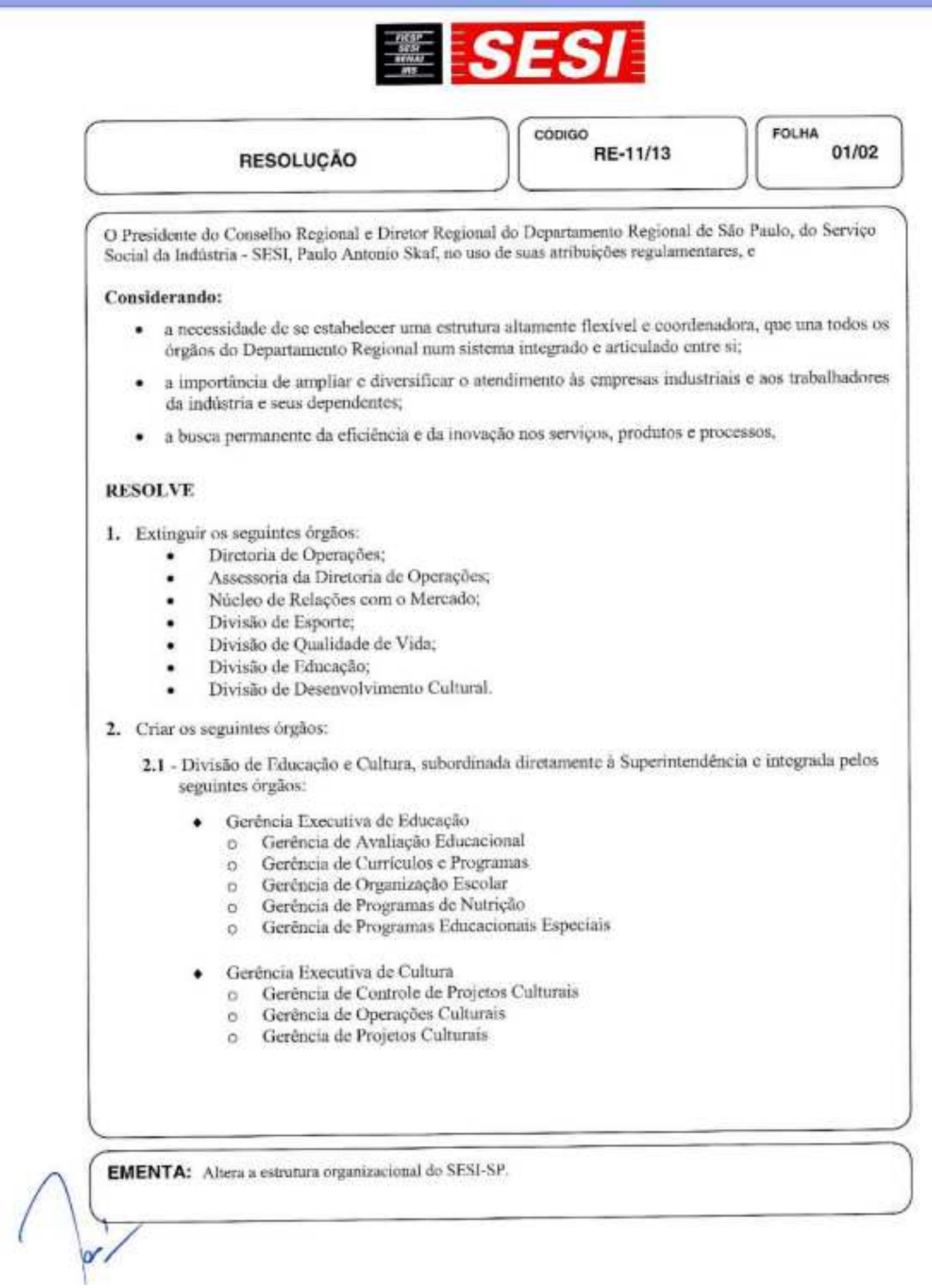


ANEXO 6 Percepção dos Coordenadores Pedagógicos acerca da prática docente dos professores de Geografia

Respostas dos Coordenadores Pedagógicos aos questionamentos.

\begin{tabular}{|c|c|c|c|}
\hline & \multicolumn{3}{|c|}{$\begin{array}{l}\text { Percepções dos Coordenadores Pedagógicos (CP) acerca da prática docente dos professores de } \\
\text { Geografia da Rede Escolar SESI-SP }\end{array}$} \\
\hline & \multicolumn{3}{|c|}{ (Grupo 01) } \\
\hline $\mathrm{CP}$ & $\begin{array}{l}01 \text { - O que caracteriza um bom professor de } \\
\text { Geografia }\end{array}$ & $\begin{array}{l}02 \text { - Que ações [do professor de } \\
\text { Geografia] mais contribuem para } \\
\text { aprendizagem dos alunos? }\end{array}$ & $\begin{array}{l}03 \text { - Quais os equívocos } \\
\text { mais comuns na prática dos } \\
\text { professores } \\
\text { Geografia]? }\end{array}$ \\
\hline 001 & $\begin{array}{l}\text { Ter conhecimento; Saber ensinar; Motivar os } \\
\text { alunos. }\end{array}$ & $\begin{array}{l}\text { Sistematização adequada; } \\
\text { Aprende para o fazer. }\end{array}$ & $\begin{array}{l}\text { Não conseguir romper com } \\
\text { a pedagogia tradicional. }\end{array}$ \\
\hline 002 & $\begin{array}{l}\text { Atuante e mobilizador; Atualizado e } \\
\text { persistente; Ter amor e vontade de ensinar. }\end{array}$ & $\begin{array}{l}\text { Mobilizar o aluno para o } \\
\text { conhecimento do conteúdo; } \\
\text { Levar o aluno a colocar a teoria } \\
\text { em sua prática diária. }\end{array}$ & $\begin{array}{l}\text { Trabalha com os conteúdos } \\
\text { os conteúdos de forma } \\
\text { decorativa sem parar parra } \\
\text { entender e buscar o } \\
\text { conhecimento na prática. }\end{array}$ \\
\hline 003 & $\begin{array}{l}\text { Profissional atualizado com as informações } \\
\text { referentes ao "Mundo"; Mobiliza o grupo; Faz } \\
\text { relações entre o passado e o presente. }\end{array}$ & $\begin{array}{l}\text { Investimento em atividades que } \\
\text { estimulem as diferentes } \\
\text { habilidades. }\end{array}$ & $\begin{array}{l}\text { Supervalorização do } \\
\text { recurso da "decoreba". }\end{array}$ \\
\hline 004 & $\begin{array}{l}\text { Aquele que consegue conciliar as questões das } \\
\text { constantes mudanças geográficas com as } \\
\text { históricas, sociais e os impactos ambientais e } \\
\text { sociais. }\end{array}$ & $\begin{array}{l}\text { A dinâmica das aulas, como deve } \\
\text { ser trabalhada a dinâmica das } \\
\text { mudanças sociais e geográficas, } \\
\text { as aulas também dever ser } \\
\text { dinâmicas. }\end{array}$ & $\begin{array}{l}\text { Pensar que somente o } \\
\text { trabalho com a parte } \\
\text { teórica sem a sua devida } \\
\text { contextualização, dará } \\
\text { conta de tudo. }\end{array}$ \\
\hline 005 & $\begin{array}{l}\text { É aquele que contextualiza as informações, } \\
\text { articulando o cotidiano com os conceitos } \\
\text { teóricos. }\end{array}$ & $\begin{array}{l}\text { Articulação da teoria com o } \\
\text { cotidiano. }\end{array}$ & $\begin{array}{l}\text { Priorizar a quantidade e } \\
\text { trabalhar superficialmente } \\
\text { a fm de cumprir as } \\
\text { expectativas [de ensino e } \\
\text { aprendizagem]. }\end{array}$ \\
\hline 006 & $\begin{array}{l}\text { Conhecimento; Dinamismo; Paixão; Motivação; } \\
\text { Utilizar deferentes recursos e estratégias. }\end{array}$ & $\begin{array}{l}\text { Contextualizar conteúdo; Traçar } \\
\text { paralelos com a vivência do } \\
\text { aluno; Envolver os alunos; } \\
\text { Promover desafios e reflexões. } \\
\end{array}$ & Nivelar aprendizagens \\
\hline 007 & $\begin{array}{l}\text { Diversificar estratégias; sair a campo com os } \\
\text { alunos }\end{array}$ & $\begin{array}{l}\text { Dinamismo, uso de tecnologias, } \\
\text { aulas prazerosas, diversidade de } \\
\text { estratégias. }\end{array}$ & $\begin{array}{l}\text { Aulas expositivas, visando a } \\
\text { memorização; avaliação. }\end{array}$ \\
\hline 008 & $\begin{array}{l}\text { Sua facilidade em mobilizar os alunos à } \\
\text { aprendizagem; O professor que consegue fazer } \\
\text { o aluno "enxergar" o espaço em que vive, } \\
\text { geograficamente, politicamente... }\end{array}$ & $\begin{array}{l}\text { A utilização dos recursos } \\
\text { pedagógicos; Exploração dos } \\
\text { espaços disponíveis; Bom } \\
\text { relacionamento com os } \\
\text { educandos. }\end{array}$ & $\begin{array}{l}\text { Excesso de textos } \\
\text { apresentados; escolha dos } \\
\text { instrumentos de avaliação } \\
\text { (focando mais o que o } \\
\text { aluno não fez) }\end{array}$ \\
\hline
\end{tabular}




\begin{tabular}{|c|c|c|c|}
\hline 009 & $\begin{array}{l}\text { Conhecimento técnico; alfabetizador } \\
\text { cartográfico; contextualizador; reflexivo; leitor } \\
\text { do mundo }\end{array}$ & $\begin{array}{l}\text { O ensino deve ter mediação; } \\
\text { contextualização; ensinar a usar } \\
\text { instrumentos, recursos com } \\
\text { habilidade; desenvolver o senso } \\
\text { político/ cidadão; espaço/ } \\
\text { mudanças, tem que ser objeto } \\
\text { das aulas }\end{array}$ & $\begin{array}{l}\text { Decorar conceitos; } \\
\text { simplificar/ reduzir; uso dos } \\
\text { recursos geográficos; } \\
\text { autoritarismo. }\end{array}$ \\
\hline 010 & $\begin{array}{l}\text { Professor que faz aula participativa; dinâmica; } \\
\text { que consiga fazer os alunos entenderem } \\
\text { localização. }\end{array}$ & $\begin{array}{l}\text { O aluno tem que ter a teoria, } \\
\text { mas o importante é colocar em } \\
\text { prática o que foi ensinado; ser } \\
\text { co-participativo no processo. }\end{array}$ & $\begin{array}{l}\text { paixão por textos e } \\
\text { reproduzi-los por escrito na } \\
\text { lousa; decorar conteúdo } \\
\text { que não leva a } \\
\text { aprendizagem. }\end{array}$ \\
\hline 011 & $\begin{array}{l}\text { Domínio do conteúdo e capacidade de } \\
\text { transposição didática. }\end{array}$ & $\begin{array}{l}\text { Aquelas que colocam o aluno } \\
\text { como indivíduo ativo e integrado } \\
\text { ao contexto da geografia física, } \\
\text { humana e política. }\end{array}$ & $\begin{array}{l}\text { professor como único } \\
\text { detentor do saber. }\end{array}$ \\
\hline 012 & $\begin{array}{l}\text { Ser dinâmico, independente do conteúdo a ser } \\
\text { trabalhado }\end{array}$ & $\begin{array}{l}\text { Uma aula bem planejada; o } \\
\text { domínio do professor, tanto do } \\
\text { conteúdo quanto o olhar de ser } \\
\text { humano. }\end{array}$ & $\begin{array}{l}\text { Muitas vezes não conseguir } \\
\text { adequar as expectativas } \\
\text { [de ensino e aprendizagem] } \\
\text { da rede. }\end{array}$ \\
\hline 013 & $\begin{array}{l}\text { Capacidade de transmitir a leitura do espaço } \\
\text { pelo aluno }\end{array}$ & $\begin{array}{l}\text { A interação entre o professor e } \\
\text { os alunos. }\end{array}$ & $\begin{array}{l}\text { Não levar em conta o } \\
\text { conhecimento dos alunos. }\end{array}$ \\
\hline 014 & $\begin{array}{l}\text { Pesquisador, provocador; atualidades do } \\
\text { mundo; Associa teoria e atividades } \\
\text { diferenciadas em parceria com outras } \\
\text { disciplinas e espaços: LIE [Laboratório de } \\
\text { Informática Educacional], biblioteca... }\end{array}$ & $\begin{array}{l}\text { Quando interagem com } \\
\text { perguntas e dialogam dúvidas } \\
\text { com os docentes; quando a } \\
\text { intencionalidade está clara para } \\
\text { o aluno e realiza de maneira } \\
\text { lúdica/ prazerosa; quando } \\
\text { articulam teoria a prática em } \\
\text { ações intencionais. }\end{array}$ & $\begin{array}{l}\text { Informar já qualifica } \\
\text { conhecimento; ensinar é } \\
\text { transmitir; número de } \\
\text { conteúdo determina a } \\
\text { aprendizagem. }\end{array}$ \\
\hline 015 & $\begin{array}{l}\text { Dinamismo; proporciona momentos de } \\
\text { reflexão sobre os assuntos abordados }\end{array}$ & $\begin{array}{l}\text { Boas estratégias de mobilização/ } \\
\text { problematização que levam o } \\
\text { aluno à investigação; boas } \\
\text { estratégias de sistematização/ } \\
\text { produção do aluno. }\end{array}$ & $\begin{array}{l}\text { Desconsiderar, muitas } \\
\text { vezes, o estilo de } \\
\text { aprendizagem dos alunos. }\end{array}$ \\
\hline 016 & $\begin{array}{l}\text { A diversidade e possibilidade em sala de aula; } \\
\text { Utilização de vários recursos; trabalhar com os } \\
\text { espaços possíveis e utilização da biblioteca e } \\
\text { informática educacional. }\end{array}$ & $\begin{array}{l}\text { A dinâmica do professor, } \\
\text { diversificando o aprendizado; o } \\
\text { visual é muito importante para a } \\
\text { memória; utilização da biblioteca } \\
\text { para ir além da sala de aula. }\end{array}$ & $\begin{array}{l}\text { É só ficar na lousa e } \\
\text { caderno; somente a leitura, } \\
\text { não levando a teoria à } \\
\text { prática e vice versa. }\end{array}$ \\
\hline 017 & $\begin{array}{l}\text { O professor que apresenta uma diversidade de } \\
\text { estratégias e uma linguagem objetiva e clara } \\
\text { aos educandos. }\end{array}$ & $\begin{array}{l}\text { Ações planejadas pelo professor } \\
\text { comprometidos com situações } \\
\text { atuais do cotidiano. }\end{array}$ & $\begin{array}{l}\text { Dificuldade de } \\
\text { complementação com } \\
\text { textos favorecendo a } \\
\text { localização. }\end{array}$ \\
\hline 018 & Criativo e inovador; questionador; preparado. & $\begin{array}{l}\text { Quando o professor proporciona } \\
\text { ao aluno oportunidades de } \\
\text { autonomia e organização. }\end{array}$ & $\begin{array}{l}\text { Quando o professor pensa } \\
\text { ser somente "ele" o } \\
\text { detentor de todo o } \\
\text { conhecimento e os alunos } \\
\text { meramente expectadores. }\end{array}$ \\
\hline
\end{tabular}




\begin{tabular}{|c|c|c|c|}
\hline 019 & $\begin{array}{l}\text { A capacidade de estabelece relação entre o } \\
\text { espaço e a representabilidade do homem } \\
\text { como interventor }\end{array}$ & $\begin{array}{l}\text { Trabalha a Geografia de forma } \\
\text { contextualizada. }\end{array}$ & $\begin{array}{l}\text { Trabalhar a Geografia } \\
\text { como uma ciência isolada } \\
\text { das demais ciências; }\end{array}$ \\
\hline 020 & $\begin{array}{l}\text { Atualizado aos conhecimentos; Facilita ao } \\
\text { aluno a compreensão do mundo, no que se } \\
\text { refere à ocupação, organização, características } \\
\text { e relações; Uso de boas estratégias. }\end{array}$ & $\begin{array}{l}\text { Troca de informações, opiniões; } \\
\text { possibilita a análise, observação } \\
\text { e levantamento de hipóteses; } \\
\text { vivência de experiências. }\end{array}$ & $\begin{array}{l}\text { Pensar que transmitir } \\
\text { todos os conhecimentos de } \\
\text { forma expositiva já é o } \\
\text { suficiente. }\end{array}$ \\
\hline 021 & $\begin{array}{l}\text { Motivado (foco); ensina com significado; } \\
\text { diálogo com os alunos (escuta); atualizado; } \\
\text { vontade de aprender; utiliza diferentes } \\
\text { estratégias de ensino. }\end{array}$ & $\begin{array}{l}\text { Motivação/ significado dos } \\
\text { conteúdos; diferentes } \\
\text { estratégias/ didática de ensino; } \\
\text { diálogo com o aluno; postura do } \\
\text { professor em sala (foco). }\end{array}$ & $\begin{array}{l}\text { Exige decorar; sem opções } \\
\text { de estratégias de ensino; } \\
\text { sem foco de trabalho. }\end{array}$ \\
\hline 022 & $\begin{array}{l}\text { A dinâmica do professor alfabetizador } \\
\text { cartográfico; reflexivo, contextualizador e } \\
\text { aberto a mudanças. }\end{array}$ & $\begin{array}{l}\text { A relação da teoria com } \\
\text { atualidades do mundo através de } \\
\text { debates, trabalho in loco. }\end{array}$ & $\begin{array}{l}\text { O trabalho teórico com } \\
\text { textos e questões sem } \\
\text { utilização dos recursos } \\
\text { didáticos. }\end{array}$ \\
\hline 023 & $\begin{array}{l}\text { Um professor que planeja suas aulas; dialoga } \\
\text { com os alunos; utiliza recursos pedagógicos } \\
\text { para visualização; um professor pesquisador e } \\
\text { dinâmico. }\end{array}$ & $\begin{array}{l}\text { Pesquisa orientada; participação } \\
\text { nas aulas; incentivo do professor; } \\
\text { vivenciar o conteúdo } \\
\text { (experiências); relacionar } \\
\text { conteúdos à realidade. }\end{array}$ & $\begin{array}{l}\text { Enfocar a decoreba, ensino } \\
\text { tradicional; não dar } \\
\text { devolutiva de atividades, } \\
\text { tarefas; não focar o diálogo } \\
\text { durante as aulas. }\end{array}$ \\
\hline 024 & $\begin{array}{l}\text { Embasamento teórico; alfabetizador } \\
\text { cartográfico. }\end{array}$ & $\begin{array}{l}\text { Contextualizar os conteúdos; } \\
\text { explorar os diferentes espaços } \\
\text { além da sala de aula; estudo do } \\
\text { meio. }\end{array}$ & Priorizar a memorização. \\
\hline 025 & $\begin{array}{l}\text { Dinâmico que utiliza diversos recursos para } \\
\text { interagir na linguagem dos alunos (os } \\
\text { conteúdos) }\end{array}$ & $\begin{array}{l}\text { Professor articulador, orientador } \\
\text { em pesquisas com alunos; } \\
\text { relacionar conteúdo com a } \\
\text { realidade. }\end{array}$ & $\begin{array}{l}\text { O decoreba; aula } \\
\text { expositiva. }\end{array}$ \\
\hline 026 & $\begin{array}{l}\text { Capacidade de atualização de conhecimentos, } \\
\text { tendo em vista as inconstâncias na vida em } \\
\text { sociedade e transformações geográficas } \\
\text { decorridas destas. }\end{array}$ & $\begin{array}{l}\text { Ações diretivas que levem em } \\
\text { conta o contexto social dos } \\
\text { alunos, para que os conteúdos } \\
\text { tenham significado para os } \\
\text { mesmos. }\end{array}$ & $\begin{array}{l}\text { Se ater a conceitos fora da } \\
\text { realidade e contexto social } \\
\text { dos alunos, levando-os a } \\
\text { reproduzirem } \\
\text { mecanicamente esses } \\
\text { conceitos. }\end{array}$ \\
\hline 027 & $\begin{array}{l}\text { Um professor que consiga ter uma visão ampla } \\
\text { deste mundo globalizado; que tenha clareza } \\
\text { das relações do homem na sociedade e nas } \\
\text { intervenções no espaço. }\end{array}$ & $\begin{array}{l}\text { Discussão/ debate de forma } \\
\text { contextualizada/ autonomia e } \\
\text { organizada }\end{array}$ & A não contextualização. \\
\hline 028 & $\begin{array}{l}\text { Articular os conteúdos com assuntos do } \\
\text { cotidiano; Dinâmico, onde utiliza diferentes } \\
\text { procedimentos metodológicos; propõe } \\
\text { pesquisas e faz devolutivas. }\end{array}$ & $\begin{array}{l}\text { Valorizar o conhecimento que os } \\
\text { alunos trazem e promover a } \\
\text { participação; identificar o } \\
\text { interesse dos alunos no tema } \\
\text { trabalhado (conteúdo). }\end{array}$ & $\begin{array}{l}\text { Tornar o conteúdo de } \\
\text { Geografia cansativo, muito } \\
\text { teórico. }\end{array}$ \\
\hline 029 & $\begin{array}{l}\text { Conhecimento teórico; alfabetizador } \\
\text { cartográfico; contextualizador; reflexivo; leitor } \\
\text { do mundo. }\end{array}$ & $\begin{array}{l}\text { Contextualizada; mediada; } \\
\text { estudo do meio. }\end{array}$ & $\begin{array}{l}\text { Decorar conceitos; } \\
\text { pergunta e resposta; } \\
\text { simplificar e reduzir o uso } \\
\text { dos recursos geográficos. }\end{array}$ \\
\hline
\end{tabular}




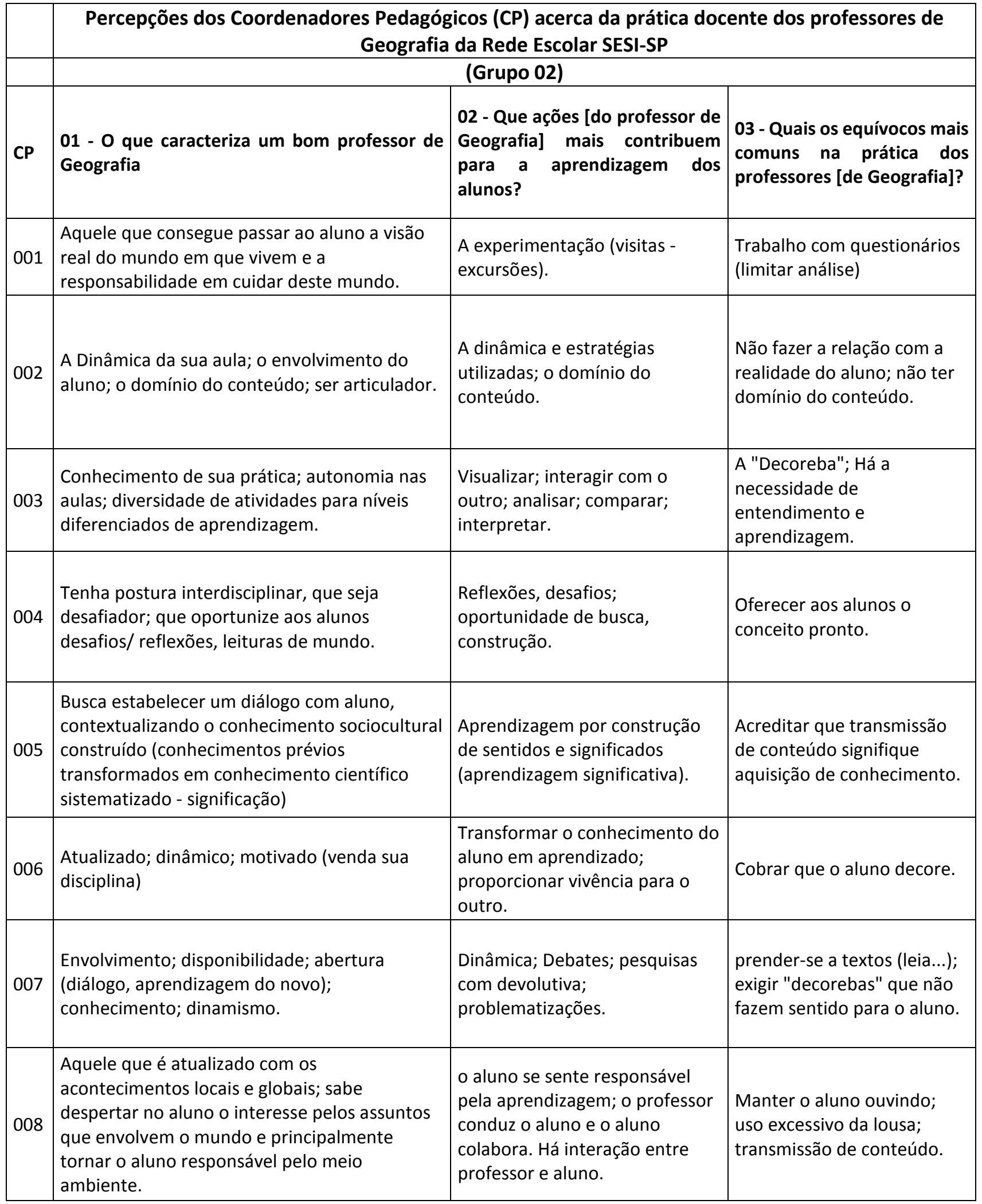




\begin{tabular}{|c|c|c|c|}
\hline 009 & $\begin{array}{l}\text { Capacidade de pesquisar e de estar atualizado } \\
\text { com novos conhecimentos. }\end{array}$ & $\begin{array}{l}\text { Aulas dinâmicas, dialogadas, } \\
\text { incentivo à pesquisa, dose } \\
\text { consciente de ludicidade. }\end{array}$ & $\begin{array}{l}\text { Aulas puramente } \\
\text { expositivas. }\end{array}$ \\
\hline 010 & $\begin{array}{l}\text { Ter um bom diálogo com os alunos } \\
\text { (comunicativo); saber ouvir; compartilhar } \\
\text { conhecimentos. }\end{array}$ & $\begin{array}{l}\text { O aluno ser o foco da } \\
\text { aprendizagem; estar envolvido } \\
\text { no seu aprendizado. }\end{array}$ & $\begin{array}{l}\text { Ser o único detentor do } \\
\text { saber; não capacitação. }\end{array}$ \\
\hline 011 & $\begin{array}{l}\text { Domínio e repertório da área. Que permita ao } \\
\text { aluno "degustar" da área de conhecimento. }\end{array}$ & $\begin{array}{l}\text { Quando o professor possui bons } \\
\text { conhecimentos gerais e } \\
\text { consegue contextualizar sua } \\
\text { área, sua prática gera bons } \\
\text { conhecimentos. }\end{array}$ & $\begin{array}{l}\text { Achar que o conhecimento } \\
\text { se encontra somente no } \\
\text { material didático e ignorar } \\
\text { outros portadores. }\end{array}$ \\
\hline 012 & $\begin{array}{l}\text { Conhecimentos específicos de sua disciplina } \\
\text { atrelados à capacidade de relacionar esses } \\
\text { conteúdos ao cotidiano dos alunos (quando } \\
\text { possível) e bom relacionamento com os jovens. }\end{array}$ & $\begin{array}{l}\text { Valorização dos conhecimentos } \\
\text { pelo professore e, por } \\
\text { consequência, pelo aluno; bom } \\
\text { relacionamento do professor } \\
\text { com os alunos, como forma de } \\
\text { motivá-los para o } \\
\text { conhecimento. }\end{array}$ & $\begin{array}{l}\text { Foco nos conteúdos } \\
\text { isoladamente, sem procurar } \\
\text { despertar o interesse do } \\
\text { aluno ou mostrar-lhe a } \\
\text { importância deste. }\end{array}$ \\
\hline 013 & $\begin{array}{l}\text { O domínio dos conteúdos (todos); A relação } \\
\text { que fica estabelecida entre as partes (alunos/ } \\
\text { professor) }\end{array}$ & $\begin{array}{l}\text { O domínio por parte do } \\
\text { professor dos conteúdos a } \\
\text { serem abordados; A relação que } \\
\text { o professor estabelece com } \\
\text { seus alunos. }\end{array}$ & $\begin{array}{l}\text { Seguir uma sequência } \\
\text { didática sem analisar a } \\
\text { realidade local. }\end{array}$ \\
\hline 014 & $\begin{array}{l}\text { Atualizado; conectado aos aspectos políticos, } \\
\text { sociais e físicos que refletem para o } \\
\text { conhecimento geral do aluno e valorize meio } \\
\text { ambiente. }\end{array}$ & $\begin{array}{l}\text { ações práticas que relacionam e } \\
\text { constroem conceitos/ } \\
\text { definições; Estudo do meio. }\end{array}$ & $\begin{array}{l}\text { Pensar que todos aprendem } \\
\text { somente em sala de aula e } \\
\text { nos livros. }\end{array}$ \\
\hline 015 & $\begin{array}{l}\text { Articular o conhecimento conceitual às } \\
\text { vivências dos alunos; atualidade, história, } \\
\text { contextualização. }\end{array}$ & $\begin{array}{l}\text { Ações, pesquisa, reflexão e } \\
\text { relação entre os conhecimentos } \\
\text { nas diferentes áreas. }\end{array}$ & $\begin{array}{l}\text { Supervalorizar o conteúdo } \\
\text { conceitual da sua disciplina. }\end{array}$ \\
\hline 016 & $\begin{array}{l}\text { Conhecimento do conteúdo e diferentes } \\
\text { estratégias para ensinar e avaliar }\end{array}$ & $\begin{array}{l}\text { Relacionamento interpessoal; } \\
\text { estratégias diversificadas de } \\
\text { ensino. }\end{array}$ & $\begin{array}{l}\text { Trabalhar com os alunos de } \\
\text { hoje da mesma maneira } \\
\text { como foram ensinados. }\end{array}$ \\
\hline 017 & $\begin{array}{l}\text { O que contextualiza; utiliza recursos } \\
\text { pedagógicos multimeios; permite que o aluno } \\
\text { arrisque, pense, pergunte, pesquise. }\end{array}$ & $\begin{array}{l}\text { Contextualização; } \\
\text { aprendizagem significativa. }\end{array}$ & $\begin{array}{l}\text { Aula expositiva basta; } \\
\text { ensinar como antes } \\
\text { (decorar) é suficiente. }\end{array}$ \\
\hline 018 & Ser interdisciplinar; & $\begin{array}{l}\text { Construir conhecimento; } \\
\text { pesquisar; relacionar o que está } \\
\text { aprendendo com a realidade (o } \\
\text { que acontece no mundo). }\end{array}$ & $\begin{array}{l}\text { Querer que o aluno decore } \\
\text { "dados"; limitar-se nos } \\
\text { muros da escola. }\end{array}$ \\
\hline 019 & $\begin{array}{l}\text { Aquele que possui estratégias variadas para a } \\
\text { prática em sala de aula. }\end{array}$ & $\begin{array}{l}\text { A vivência concreta das } \\
\text { atividades (mapas, maquetes, } \\
\text { jogos.) }\end{array}$ & $\begin{array}{l}\text { Passar os conteúdos sem a } \\
\text { formação de conceitos. E a } \\
\text { decoreba. }\end{array}$ \\
\hline 020 & $\begin{array}{l}\text { Ser atualizado e conectado com as questões } \\
\text { mundiais. }\end{array}$ & $\begin{array}{l}\text { Aulas dinâmicas, com utilização } \\
\text { de diversos recursos e } \\
\text { estratégias; questões } \\
\text { desafiadoras. }\end{array}$ & $\begin{array}{l}\text { Valorizar as práticas } \\
\text { decorativas. }\end{array}$ \\
\hline
\end{tabular}




\begin{tabular}{|c|c|c|c|}
\hline 021 & $\begin{array}{l}\text { O professor que leva seus alunos a serem } \\
\text { capazes de fazerem uma leitura do mundo } \\
\text { desse espaço. }\end{array}$ & $\begin{array}{l}\text { ações que levem os alunos a } \\
\text { refletirem, a questionarem, a } \\
\text { encontrar soluções, a fazer } \\
\text { relação da geografia com sua } \\
\text { realidade. }\end{array}$ & $\begin{array}{l}\text { Acharem que devem encher } \\
\text { a lousa de conteúdos, que } \\
\text { através de questionários } \\
\text { com respostas prontas, } \\
\text { através da "decoreba" estão } \\
\text { proporcionando atividades e } \\
\text { aprendizagens significativas. }\end{array}$ \\
\hline 022 & $\begin{array}{l}\text { Boa comunicação; preocupação com o meio } \\
\text { ambiente (militâncias); sensibilidade social. }\end{array}$ & $\begin{array}{l}\text { Ações de proteção do meio } \\
\text { ambiente; trabalhos de campo } \\
\text { (observação); engajamento em } \\
\text { projetos ambientais. }\end{array}$ & $\begin{array}{l}\text { decoreba de lugares, } \\
\text { acidentes, etc.; } \\
\text { Exclusividade de sala de } \\
\text { aula; trabalho técnico } \\
\text { deslocado do mundo real. }\end{array}$ \\
\hline 023 & $\begin{array}{l}\text { Clareza, organização; paixão pela disciplina e } \\
\text { contágio aos alunos. }\end{array}$ & $\begin{array}{l}\text { Utilização de recursos diversos } \\
\text { como pesquisa, audiovisuais, } \\
\text { etc.; reflexão sobre a prática; } \\
\text { retomada. }\end{array}$ & $\begin{array}{l}\text { Ficar muito só na teoria; } \\
\text { Achar que a maneira de } \\
\text { ensinar é certa e única. }\end{array}$ \\
\hline 024 & Conhecimento & $\begin{array}{l}\text { Mediação no processo de } \\
\text { ensino e aprendizagem dos } \\
\text { alunos. }\end{array}$ & $\begin{array}{l}\text { Acreditar que os alunos } \\
\text { sabem tudo. }\end{array}$ \\
\hline 025 & $\begin{array}{l}\text { Fornecer instrumentos para que no aluno } \\
\text { compreenda a Geografia e os ramos que } \\
\text { partem desta noção. }\end{array}$ & $\begin{array}{l}\text { Leitura, pesquisas, debates, } \\
\text { situações que proporcionem } \\
\text { reflexão e necessitem de } \\
\text { análise. }\end{array}$ & $\begin{array}{l}\text { Querer que os alunos } \\
\text { decorem ao invés de } \\
\text { compreenderem. }\end{array}$ \\
\hline 026 & Ser comunicativo. & $\begin{array}{l}\text { Domínio do conteúdo; } \\
\text { inovador; pesquisador. }\end{array}$ & conteudista. \\
\hline 027 & $\begin{array}{l}\text { Saber; saber fazer; ter foco no aluno; saber } \\
\text { como o aluno aprende. }\end{array}$ & $\begin{array}{l}\text { Contextualização; ensinar para } \\
\text { vida; viver o conteúdo. }\end{array}$ & $\begin{array}{l}\text { Crere somente no conteúdo } \\
\text { de sua disciplina. }\end{array}$ \\
\hline 028 & Comunicativo. & Diálogo; interatividade. & conteudista. \\
\hline 029 & $\begin{array}{l}\text { A articulação entre história } X \text { geografia } X \\
\text { biologia/ ambiente } X \text { política. }\end{array}$ & $\begin{array}{l}\text { Visão ampliada de mediador do } \\
\text { físico X político X humano; uso } \\
\text { de tecnologias; debates, fóruns, } \\
\text { etc. }\end{array}$ & $\begin{array}{l}\text { Apenas práticas de leituras, } \\
\text { resumos; Não uso de } \\
\text { ferramentas tecnológicas } \\
\text { como google earth; uso } \\
\text { apenas de livros didáticos. }\end{array}$ \\
\hline 030 & $\begin{array}{l}\text { Aquele que domina o conteúdo a ser } \\
\text { trabalhado e ao mesmo tempo faz com que o } \\
\text { aluno faça a correlação do mesmo com o dia-a- } \\
\text { dia. }\end{array}$ & $\begin{array}{l}\text { Quando ele identifica e coloca } \\
\text { em prática o que ele aprendeu. }\end{array}$ & $\begin{array}{l}\text { Somente a transmissão de } \\
\text { conhecimento ou conteúdo. }\end{array}$ \\
\hline 031 & $\begin{array}{l}\text { Um professor que faz trabalho de campo; que } \\
\text { orienta pesquisas corretamente e leva o aluno } \\
\text { a refletir sobre as mudanças do ambiente. }\end{array}$ & $\begin{array}{l}\text { Visitas para constatação das } \\
\text { realidades; Debates; Pesquisas. }\end{array}$ & $\begin{array}{l}\text { Não ensinar nomes de } \\
\text { países, digo a localizar } \\
\text { nomes de países nos mapas } \\
\text { ou seja geopolítica. }\end{array}$ \\
\hline 032 & Valoriza a qualidade, não a quantidade. & $\begin{array}{l}\text { Diversificar a prática; trabalhos } \\
\text { em grupos; análise e retomadas } \\
\text { dos erros, etc. }\end{array}$ & $\begin{array}{l}\text { Muita aula expositiva; muita } \\
\text { avaliação objetiva. }\end{array}$ \\
\hline 033 & $\begin{array}{l}\text { O professor que utiliza diversas estratégias de } \\
\text { ensino. }\end{array}$ & $\begin{array}{l}\text { Trabalhar com o concreto e } \\
\text { relacionar os assuntos com a } \\
\text { vivência dos alunos. }\end{array}$ & $\begin{array}{l}\text { O ensino através da } \\
\text { memorização. }\end{array}$ \\
\hline
\end{tabular}




\begin{tabular}{|c|c|c|c|}
\hline & \multicolumn{3}{|c|}{$\begin{array}{c}\text { Percepções dos Coordenadores Pedagógicos (CP) acerca da prática docente dos professores } \\
\text { de Geografia da Rede Escolar SESI-SP }\end{array}$} \\
\hline & \multicolumn{3}{|c|}{ (Grupo 03) } \\
\hline CP & $\begin{array}{l}01 \text { - O que caracteriza um bom } \\
\text { professor de Geografia }\end{array}$ & $\begin{array}{l}02 \text { - Que ações [do professor de } \\
\text { Geografia] mais contribuem para a } \\
\text { aprendizagem dos alunos? }\end{array}$ & $\begin{array}{l}03 \text { - Quais os equívocos mais } \\
\text { comuns na prática dos } \\
\text { professores [de Geografia]? }\end{array}$ \\
\hline 001 & $\begin{array}{l}\text { Aquele que domina os conteúdos e } \\
\text { sabe articular com os alunos }\end{array}$ & Ações práticas, visitas e pesquisas & $\begin{array}{l}\text { Se aterem a textos e } \\
\text { conteúdos propriamente } \\
\text { dito. }\end{array}$ \\
\hline 002 & $\begin{array}{l}\text { Domina os conteúdos; Oportuniza o } \\
\text { alunos; Construir o conhecimentos }\end{array}$ & $\begin{array}{l}\text { Mediar a construção do } \\
\text { conhecimento; }\end{array}$ & $\begin{array}{l}\text { Transmitir o conhecimento; } \\
\text { Trazer o conhecimento } \\
\text { pronto. }\end{array}$ \\
\hline 003 & $\begin{array}{l}\text { Que seja conhecedor dos conteúdos } \\
\text { e relevância da área. }\end{array}$ & $\begin{array}{l}\text { Relacionar com a vivência do alunos; } \\
\text { Material utilizado(mapas, imagens e } \\
\text { etc.) }\end{array}$ & $\begin{array}{l}\text { Falta conhecimento e } \\
\text { domínio do conteúdo; } \\
\text { Somente aulas expositivas; } \\
\text { Atividades que visam } \\
\text { somente a memorização. } \\
\end{array}$ \\
\hline 004 & $\begin{array}{l}\text { Um professor que consiga articular } \\
\text { o conteúdo, habilidades e a } \\
\text { realidade do aluno. }\end{array}$ & $\begin{array}{l}\text { Escolha de bons materiais, } \\
\text { atualidades, contextualizar o } \\
\text { conteúdo. }\end{array}$ & $\begin{array}{l}\text { Conteúdo sem } \\
\text { contextualização, sem } \\
\text { sentido para o aluno, } \\
\text { somente decorar. } \\
\end{array}$ \\
\hline 005 & $\begin{array}{l}\text { Estar sempre atualizado; Saber o } \\
\text { conteúdo; Aulas dinâmicas. }\end{array}$ & $\begin{array}{l}\text { Contextualização; Motivação; } \\
\text { Situações práticas e lúdicas } \\
\text { despertam o interesse dele; } \\
\text { Entender o "porquê" do conteúdo. }\end{array}$ & $\begin{array}{l}\text { Ensinar achando que aquilo } \\
\text { que é obvio para ele é } \\
\text { também para o aluno }\end{array}$ \\
\hline 006 & $\begin{array}{l}\text { Um profissional atualizado, que leve } \\
\text { aos alunos questões de análise e } \\
\text { comparação de dados. }\end{array}$ & $\begin{array}{l}\text { Atividades significativas (realidade } \\
\text { do aluno); Expressão da } \\
\text { aprendizagem de forma lúdica. }\end{array}$ & $\begin{array}{l}\text { Memorização de dados } \\
\text { (fatos, datas); } \\
\text { Não situar os locais em } \\
\text { planisférios - globo. }\end{array}$ \\
\hline 007 & $\begin{array}{l}\text { Domina o conteúdo e sabe transmiti } \\
\text {-lo interagindo com os alunos. }\end{array}$ & $\begin{array}{l}\text { Relacionar conteúdo com a vivência } \\
\text { do aluno; Utilizar - se de vários } \\
\text { materiais didáticos. }\end{array}$ & $\begin{array}{l}\text { Aula expositiva; Não domina } \\
\text { conteúdo. }\end{array}$ \\
\hline 008 & $\begin{array}{l}\text { A habilidade de associar o conteúdo } \\
\text { trabalhado com o cotidiano. }\end{array}$ & $\begin{array}{l}\text { A contextualização; O dinamismo; } \\
\text { Levar o aluno a vivenciar, dentro do } \\
\text { possível, a teoria. }\end{array}$ & $\begin{array}{l}\text { Achar que o aluno precisa } \\
\text { decorar informações; Achar } \\
\text { que o aluno sabe como } \\
\text { estudar. }\end{array}$ \\
\hline 009 & $\begin{array}{l}\text { Um professor antenado à realidade. } \\
\text { Que estimule o aluno para a } \\
\text { descoberta; Que estimule a } \\
\text { curiosidade }\end{array}$ & $\begin{array}{l}\text { O exercício da prática; Análise da } \\
\text { teoria a prática }\end{array}$ & $\begin{array}{l}\text { Prender -se a metodologias } \\
\text { tradicionais de } \\
\text { questionários e de produção } \\
\text { de mapas. }\end{array}$ \\
\hline 010 & $\begin{array}{l}\text { Contextualizar os conhecimentos } \\
\text { específicos da área com as vivências } \\
\text { do aluno, buscando dar significado à } \\
\text { aprendizagem. }\end{array}$ & $\begin{array}{l}\text { Oportunizar vivências aos alunos, } \\
\text { experiências relacionadas aos } \\
\text { conteúdos trabalhados. }\end{array}$ & $\begin{array}{l}\text { Focar na memorização de } \\
\text { informações. }\end{array}$ \\
\hline 011 & $\begin{array}{l}\text { Incentiva a pesquisa; É pesquisador; } \\
\text { Relaciona a teoria à prática. }\end{array}$ & Alunos participativos do processo. & Aulas muitos expositivas. \\
\hline 012 & $\begin{array}{l}\text { Domínio do conteúdo; } \\
\text { Organização didática. }\end{array}$ & $\begin{array}{l}\text { Dinâmica da aula; } \\
\text { Utilizar pesquisa. }\end{array}$ & $\begin{array}{l}\text { Aula somente expositiva } \\
\text { sem utilizar outros recursos. }\end{array}$ \\
\hline
\end{tabular}




\begin{tabular}{|c|c|c|c|}
\hline 013 & $\begin{array}{l}\text { Dinâmico;Criativos;Saber utilizar } \\
\text { diferentes } \\
\text { recursos;Atualizado;Saber } \\
\text { contextualizar a prática. }\end{array}$ & $\begin{array}{l}\text { Ensino contextualizado e } \\
\text { significativos para os } \\
\text { alunos;Diversificação das estratégias } \\
\text { da aula. }\end{array}$ & $\begin{array}{l}\text { Ser conteudista;Trabalhar } \\
\text { com o conteúdo decorado } \\
\text { e sem compreensão. }\end{array}$ \\
\hline 014 & $\begin{array}{l}\text { Conhecimento; } \\
\text { Atualização; } \\
\text { Didática/ estratégias diversificadas }\end{array}$ & $\begin{array}{l}\text { Pesquisa; } \\
\text { Atividades significativas. }\end{array}$ & Memorização. \\
\hline 015 & $\begin{array}{l}\text { Boas estratégias; } \\
\text { Boa didática; } \\
\text { Conhecimento. }\end{array}$ & $\begin{array}{l}\text { Ações práticas (maquetes, mapas e } \\
\text { etc.); } \\
\text { Pesquisas; } \\
\text { Exposições. }\end{array}$ & $\begin{array}{l}\text { Formação de grupos } \\
\text { produtivos. }\end{array}$ \\
\hline 016 & $\begin{array}{l}\text { Domínio de conteúdos; } \\
\text { Proporcionar relação entre } \\
\text { conceitos políticos, econômicos, } \\
\text { religiosos, éticos. }\end{array}$ & $\begin{array}{l}\text { Atividades que atendam à realidade } \\
\text { das classes; } \\
\text { Discussão / debates de assuntos } \\
\text { atuais. }\end{array}$ & $\begin{array}{l}\text { Não dar vez e voz ao aluno; } \\
\text { Utilização de questionários. }\end{array}$ \\
\hline 017 & $\begin{array}{l}\text { Aquele que relaciona o conteúdo } \\
\text { com a vida prática }\end{array}$ & $\begin{array}{l}\text { A diversidade de materiais } \\
\text { pedagógicos que articulem o saber } \\
\text { (conteúdo) ao significado }\end{array}$ & o uso de aulas expositivas. \\
\hline 018 & $\begin{array}{l}\text { Professor que alia realidade às suas } \\
\text { propostas. }\end{array}$ & $\begin{array}{l}\text { Dinamismo na sistematização; } \\
\text { Diversificação de atividades. }\end{array}$ & Ater -se a aula expositiva. \\
\hline 019 & $\begin{array}{l}\text { Aulas dinâmicas o aluno aprende e } \\
\text { fica motivado; Utiliza recursos; } \\
\text { Desenvolver a alfabetização } \\
\text { geográfica e cartográfica. }\end{array}$ & $\begin{array}{l}\text { Uso de imagens, mapas, debates, } \\
\text { comparações; Contextualização da } \\
\text { Geografia; Problematização do } \\
\text { conteúdo; Diferentes recursos; }\end{array}$ & $\begin{array}{l}\text { Uso somente de } \\
\text { questionário; } \\
\text { Trabalho só no conteúdo } \\
\text { conceitual, de forma } \\
\text { decorativa; Aula expositiva } \\
\text { sem participação do aluno. }\end{array}$ \\
\hline 020 & $\begin{array}{l}\text { Domina o conteúdo; pesquisador } \\
\text { (vai em busca); Atualizado; } \\
\text { Cativante em relação ao seu } \\
\text { componente. }\end{array}$ & $\begin{array}{l}\text { Um bom planejamento (boas } \\
\text { oportunidades, estratégias). }\end{array}$ & $\begin{array}{l}\text { O professor tornar rotineira } \\
\text { sua aula. }\end{array}$ \\
\hline 021 & Domínio do conteúdo. & $\begin{array}{l}\text { Aulas dinâmicas; Uso de atlas, } \\
\text { imagens ... }\end{array}$ & $\begin{array}{l}\text { Uso de questionários; } \\
\text { memorização do conteúdo. }\end{array}$ \\
\hline 022 & $\begin{array}{l}\text { Conhecimento da área; } \\
\text { Comprometimento; Facilidade de } \\
\text { transmitir conteúdos; Desenvolve } \\
\text { habilidades. }\end{array}$ & $\begin{array}{l}\text { Aulas motivadoras; Professor } \\
\text { demonstrando conhecimento; } \\
\text { Contextualização e estratégias } \\
\text { variadas. }\end{array}$ & $\begin{array}{l}\text { Aulas expositivas; Aplicação } \\
\text { de questionário }\end{array}$ \\
\hline 023 & $\begin{array}{l}\text { Contextualiza os conhecimentos; } \\
\text { Leva em consideração o senso } \\
\text { comum dos alunos. }\end{array}$ & $\begin{array}{l}\text { Contextualização da Geografia; } \\
\text { Desenvolver a alfabetização } \\
\text { geográfica e cartográfica }\end{array}$ & $\begin{array}{l}\text { Fica somente no conteúdo } \\
\text { conceitual; } \\
\text { Na memorização; Na } \\
\text { habilidade de localizar. } \\
\end{array}$ \\
\hline 024 & $\begin{array}{l}\text { Domínio dos conteúdos; Relação } \\
\text { interpessoal; Facilidade em } \\
\text { transmitir conhecimento. }\end{array}$ & $\begin{array}{l}\text { Conteúdos significativos; } \\
\text { Contextualização; Estratégias } \\
\text { diversificadas }\end{array}$ & Aplicação de questionários. \\
\hline 025 & $\begin{array}{l}\text { Aquele que consegue articular o } \\
\text { conteúdo ao cotidiano de maneira } \\
\text { dinâmica. }\end{array}$ & $\begin{array}{l}\text { Uso de estratégias variadas e } \\
\text { atividades contextualizadas. }\end{array}$ & $\begin{array}{l}\text { Aplicação de questionário e } \\
\text { de simples localização. }\end{array}$ \\
\hline 026 & $\begin{array}{l}\text { Criativo; Ter conhecimento técnico } \\
\text { da sua disciplina; Ser um articulador } \\
\text { dinâmico na sala de aula. }\end{array}$ & $\begin{array}{l}\text { Direcionar os alunos ao aprendizado } \\
\text { mais dinâmico; Conduzir a construir } \\
\text { o próprio conhecimento (pesquisa, } \\
\text { seminário) }\end{array}$ & $\begin{array}{l}\text { Trabalha com os alunos de } \\
\text { forma conteudista; Não } \\
\text { contextualizar a Geografia.. }\end{array}$ \\
\hline
\end{tabular}




\begin{tabular}{|c|c|c|c|}
\hline 027 & $\begin{array}{l}\text { Domínio do conteúdo; Cuidar da } \\
\text { relação (postura). }\end{array}$ & $\begin{array}{l}\text { Postura dialógica (promover } \\
\text { participação do aluno para } \\
\text { construção do conhecimento). }\end{array}$ & $\begin{array}{l}\text { Aplicabilidade de } \\
\text { questionários.Memorização; } \\
\text { Falta de leitura e } \\
\text { sistematização. }\end{array}$ \\
\hline 028 & $\begin{array}{l}\text { Que domine o conteúdo; Que tenha } \\
\text { uma didática. }\end{array}$ & $\begin{array}{l}\text { diversificação da prática, interação, } \\
\text { atividades contextualizadas. }\end{array}$ & $\begin{array}{l}\text { os que focam na } \\
\text { memorização e reprodução } \\
\text { de mapas, países estados e } \\
\text { etc. }\end{array}$ \\
\hline 029 & $\begin{array}{l}\text { Domínio na disciplina; Boas } \\
\text { estratégias para o aprendizado e } \\
\text { motivação. }\end{array}$ & $\begin{array}{l}\text { Envolvimento dos alunos através de } \\
\text { exposições claras, contextualização, } \\
\text { participação dos grupos de alunos. }\end{array}$ & $\begin{array}{l}\text { Trabalha com muita } \\
\text { memorização sem a devida } \\
\text { contextualização. }\end{array}$ \\
\hline 030 & $\begin{array}{l}\text { Domínio de conteúdo e da } \\
\text { concepção pedagógica da sua área } \\
\text { de conhecimento. }\end{array}$ & $\begin{array}{l}\text { Partir da mobilização, } \\
\text { conhecimentos prévios, } \\
\text { sistematização (conteúdo), } \\
\text { problematização, exposição, } \\
\text { seminário, maquete, filme e etc. }\end{array}$ & em branco \\
\hline 031 & $\begin{array}{l}\text { Dominar o conteúdo; Interação e } \\
\text { domínio da sala. }\end{array}$ & $\begin{array}{l}\text { Aula diversificada; Contextualizada; } \\
\text { Interação professor e aluno. }\end{array}$ & $\begin{array}{l}\text { Desmotivação dos alunos; } \\
\text { Aulas expositivas (só ele que } \\
\text { fala); } \\
\text { Professor transmissor e não } \\
\text { mediador. }\end{array}$ \\
\hline 032 & $\begin{array}{l}\text { Conhecimento e uma boa didática } \\
\text { no processo de ensino - } \\
\text { aprendizagem. }\end{array}$ & $\begin{array}{l}\text { Aulas motivadoras: material e } \\
\text { pesquisa diferenciada com } \\
\text { resultados significantes. }\end{array}$ & 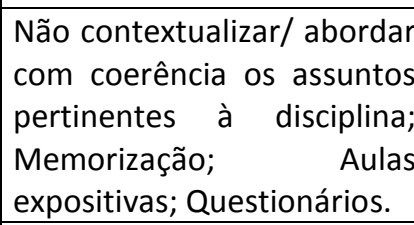 \\
\hline 033 & $\begin{array}{l}\text { Quando ele consegue dominar os } \\
\text { conteúdos de forma a trazer os } \\
\text { alunos para a interação e } \\
\text { participação no processo de ensino } \\
\text { aprendizagem. }\end{array}$ & $\begin{array}{l}\text { Aulas diversificadas } \\
\text { contextualizadas. }\end{array}$ & $\begin{array}{l}\text { Aulas expositivas e somente } \\
\text { transmissivas, sendo assim o } \\
\text { transmissor e não mediador }\end{array}$ \\
\hline
\end{tabular}

\begin{tabular}{|c|c|c|c|}
\hline & \multicolumn{3}{|c|}{$\begin{array}{c}\text { Percepções dos Coordenadores Pedagógicos (CP) acerca da prática docente dos professores } \\
\text { de Geografia da Rede Escolar SESI-SP }\end{array}$} \\
\hline & \multicolumn{3}{|c|}{ (Grupo 04) } \\
\hline $\mathrm{CP}$ & $\begin{array}{l}01 \text { - } 0 \text { que caracteriza um bom professor de } \\
\text { Geografia }\end{array}$ & $\begin{array}{l}02 \text { - Que ações [do professor de } \\
\text { Geografia] mais contribuem para } \\
\text { a aprendizagem dos alunos? }\end{array}$ & $\begin{array}{l}03 \text { - Quais os equívocos } \\
\text { mais comuns na } \\
\text { prática dos professores } \\
\text { [de Geografia]? }\end{array}$ \\
\hline 001 & $\begin{array}{l}\text { O professor que ensina, baseado nas } \\
\text { expectativas de ensino e aprendizagem e o } \\
\text { aluno consegue aprender. }\end{array}$ & $\begin{array}{l}\text { Motivação, } \quad \text { investigação e } \\
\text { construção } \\
\text { relacionados à } \\
\text { do aluno) }\end{array}$ & $\begin{array}{l}\text { Afirmar que as coisas } \\
\text { não vão dar certo, } \\
\text { antes mesmo de tentar; } \\
\text { não saber o que o aluno } \\
\text { já sabe (partir do que } \\
\text { considera que o aluno } \\
\text { deva saber). }\end{array}$ \\
\hline 002 & Dinamismo; diferentes abordagens & $\begin{array}{l}\text { Diversidade de recursos para } \\
\text { apresentação; formulação de } \\
\text { questões pertinentes. }\end{array}$ & $\begin{array}{l}\text { Textos escritos na } \\
\text { lousa; aula expositiva e } \\
\text { tradicional. }\end{array}$ \\
\hline 003 & $\begin{array}{l}\text { Que desafia o aluno; Busca constantemente } \\
\text { estratégias diferentes para o trabalho, } \\
\text { porém, todas contextualizadas. }\end{array}$ & $\begin{array}{l}\text { A contextualização; uso de } \\
\text { diversos materiais }\end{array}$ & $\begin{array}{ll}\text { Basear-se } & \text { somente em } \\
\text { textos prontos e } \\
\text { mapas... }\end{array}$ \\
\hline
\end{tabular}




\begin{tabular}{|c|c|c|c|}
\hline 004 & Atualizado e didático & $\begin{array}{l}\text { Visualização } \text { (recursos didáticos); } \\
\text { pesquisa; utilizar diferentes } \\
\text { espaços. }\end{array}$ & $\begin{array}{l}\text { Não utilizar mapas; } \\
\text { cobrar localização nos } \\
\text { mapas (avaliações) }\end{array}$ \\
\hline 005 & $\begin{array}{l}\text { Deve ser flexível. Trazer diferentes } \\
\text { estratégias de ensino e aprendizagem. }\end{array}$ & $\begin{array}{l}\text { Fazer desafios; utilizar diferentes } \\
\text { materiais: áudio, vídeo, imagens. }\end{array}$ & $\begin{array}{l}\text { Querer que todos os } \\
\text { alunos aprendam da } \\
\text { mesma forma. }\end{array}$ \\
\hline 006 & $\begin{array}{l}\text { Domínio do conteúdo, atualizado, } \\
\text { pesquisador; Sabe usar os recursos didáticos } \\
\text { disponíveis: mapas, vídeos. }\end{array}$ & $\begin{array}{l}\text { Saber usar os recursos } \\
\text { disponíveis; dinâmica da sala de } \\
\text { aula. }\end{array}$ & $\begin{array}{l}\text { Só trabalhar com livro, } \\
\text { textos, questionários! }\end{array}$ \\
\hline 007 & $\begin{array}{l}\text { Considera a realidade e os conhecimentos } \\
\text { gerais e geográficos do aluno; articula a } \\
\text { realidade ao conhecimento espacial e } \\
\text { temporal. }\end{array}$ & $\begin{array}{l}\text { Atividades significativas que } \\
\text { partem da realidade concreta. }\end{array}$ & $\begin{array}{l}\text { A } \quad \text { ausência } \\
\text { contextualização }\end{array}$ \\
\hline 008 & $\begin{array}{l}\text { O domínio na sua área de conhecimento; } \\
\text { provocador, promove a reflexão e a busca } \\
\text { pelo saber; desenvolve no aluno a postura } \\
\text { investigadora. }\end{array}$ & $\begin{array}{l}\text { Que promovam a interação - } \\
\text { alunos ativos; trabalhar com } \\
\text { situações reais. }\end{array}$ & $\begin{array}{l}\text { Que vão receber os } \\
\text { alunos da série anterior } \\
\text { prontos enquanto } \\
\text { conteúdo série. }\end{array}$ \\
\hline 009 & Que contextualiza, aliando a teoria à prática. & $\begin{array}{l}\text { Quando ele pode construir seu } \\
\text { conhecimento através da prática } \\
\text { e partindo da atualidade (geo - } \\
\text { física e política) }\end{array}$ & $\begin{array}{l}\text { Quando trabalha } \\
\text { somente na sala de aula } \\
\text { - não explora outros } \\
\text { espaços. }\end{array}$ \\
\hline 010 & $\begin{array}{l}\text { Um bom professor é capaz de fornecer } \\
\text { subsídios aos seus alunos articulando e } \\
\text { promovendo a leitura gráfica aos seus } \\
\text { alunos. }\end{array}$ & $\begin{array}{l}\text { Intervir no ensino-aprendizagem, } \\
\text { através de } \quad \text { situações } \\
\text { questionadoras; } \quad \text { oferecer } \\
\text { relações da construção do } \\
\text { pensamento instigando o aluno }\end{array}$ & $\begin{array}{l}\text { Falta de uso de } \\
\text { materiais próprios para } \\
\text { a disciplina geografia; } \\
\text { maior exploração do } \\
\text { espaço físico. }\end{array}$ \\
\hline 011 & $\begin{array}{l}\text { O que pesquisa e ensina o aluno a pesquisar; } \\
\text { ouve o aluno e trabalha com suas hipóteses. }\end{array}$ & $\begin{array}{l}\text { Pesquisas bem orientadas; o } \\
\text { trabalho com as hipóteses dos } \\
\text { alunos; trabalhos em grupos bem } \\
\text { mediados. }\end{array}$ & $\begin{array}{llr}\text { Acreditar que } & \text { os } \\
\text { seminários por } & \text { só } \\
\text { garantem } & & \text { a } \\
\text { aprendizagem. } & \end{array}$ \\
\hline 012 & $\begin{array}{l}\text { Domínio do conteúdo; utiliza diferentes } \\
\text { recursos para levar os alunos a conhecerem } \\
\text { geograficamente o mundo em que vivem; } \\
\text { dinâmico; investigador; curioso. }\end{array}$ & $\begin{array}{l}\text { Trabalhar os conteúdos e } \\
\text { habilidades utilizando recursos } \\
\text { visuais e contextualizar sempre. }\end{array}$ & $\begin{array}{l}\text { Memorização; utilizar } \\
\text { mapas somente em } \\
\text { momentos pontuais. }\end{array}$ \\
\hline 013 & $\begin{array}{l}\text { Mediador, reflexivo, sociointeracionista, que } \\
\text { leva o aluno a pensar e justificar suas ideias. }\end{array}$ & $\begin{array}{l}\text { A pesquisa, construção de } \\
\text { maquetes e mapas junto com o } \\
\text { professor; ter uma sequência } \\
\text { didática e fazer sempre } \\
\text { intervenções na aula. }\end{array}$ & $\begin{array}{l}\text { Localizar o nome dos } \\
\text { países num mapa sem } \\
\text { nome nenhum. }\end{array}$ \\
\hline 014 & $\begin{array}{l}\text { Além do conhecimento revelado na sua } \\
\text { prática, promove a motivação pelo } \\
\text { aprender. }\end{array}$ & $\begin{array}{l}\text { Quando os professores trabalham } \\
\text { com a interdisciplinaridade } \\
\text { (geografia, história sociologia) }\end{array}$ & $\begin{array}{lr}\text { Ignorar } & \text { o } \\
\text { conhecimento prévio } \\
\text { dos alunos. }\end{array}$ \\
\hline 015 & $\begin{array}{l}\text { Aquele que consegue contextualizar os } \\
\text { conteúdos; aquele que não usa só teoria, } \\
\text { mas também a prática. }\end{array}$ & $\begin{array}{l}\text { Aproximar os conteúdos da } \\
\text { realidade dos alunos; tornar, na } \\
\text { medida do possível, a sala um } \\
\text { "cenário" para sua aula. }\end{array}$ & $\begin{array}{l}\text { Aulas estritamente } \\
\text { teóricas; não saber } \\
\text { tornar os conteúdos ao } \\
\text { alcance dos alunos }\end{array}$ \\
\hline 016 & $\begin{array}{l}\text { Conhecimento teórico; dinamismo e poder } \\
\text { de comunicação. }\end{array}$ & $\begin{array}{l}\text { Boa comunicação (didática); } \\
\text { clareza na ligação entre os temas; } \\
\text { capacidade de síntese. }\end{array}$ & $\begin{array}{l}\text { Acreditar que basta } \\
\text { ensinar e o aluno } \\
\text { aprende logo no } \\
\text { primeiro momento. }\end{array}$ \\
\hline
\end{tabular}




\begin{tabular}{|c|c|c|c|}
\hline 017 & $\begin{array}{l}\text { Comprometimento; estudioso; aquele que } \\
\text { usa diferentes recursos; }\end{array}$ & $\begin{array}{l}\text { Uso da contextualização; } \\
\text { deferentes recursos (mapas, data } \\
\text { show, etc.) }\end{array}$ & 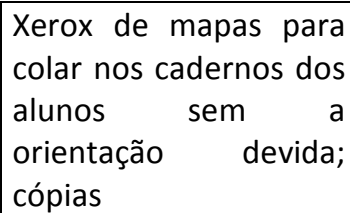 \\
\hline 018 & $\begin{array}{l}\text { Incentiva o aluno (e ensina) a ser } \\
\text { investigador. }\end{array}$ & estratégias; & $\begin{array}{l}\text { "Esperar" que os alunos } \\
\text { saibam todos os } \\
\text { conteúdos "da série } \\
\text { anterior" }\end{array}$ \\
\hline 019 & $\begin{array}{l}\text { Postura dinâmica e pesquisadora: não fica } \\
\text { preso ao livro, mas sim, procura trabalhar } \\
\text { com materiais diversos (fontes diversas) sobr } \\
\text { cada assunto, como: livros, revistas, recortes } \\
\text { de jornais, mapas, vídeos (filmes, } \\
\text { documentários) para enriquecer sua aula. }\end{array}$ & $\begin{array}{l}\text { As sondagens para trabalhar e } \\
\text { aprofundar a partir do que o } \\
\text { aluno já sabe; incentivo à } \\
\text { pesquisa e análise de materiais } \\
\text { diversos sobre o assunto; } \\
\text { pesquisa de campo, passeios a } \\
\text { locais que evidenciam algum } \\
\text { conteúdo, quando possível. }\end{array}$ & $\begin{array}{l}\text { Que o aluno entenda o } \\
\text { professor apenas pelo } \\
\text { oral (Ex.: quando fala } \\
\text { de região/ países e liga } \\
\text { aos costumes - quando } \\
\text { o aluno não possui } \\
\text { referências pessoais. } \\
\text { Ficaria mais fácil } \\
\text { visualizar algum } \\
\text { material para facilitar o } \\
\text { entendimento. }\end{array}$ \\
\hline 020 & $\begin{array}{l}\text { A sua prática, didática; relacionamento } \\
\text { positivo entre professor e alunos; } \\
\text { conhecimento teórico. }\end{array}$ & $\begin{array}{l}\text { Boa relação professor/ aluno; } \\
\text { maior conhecimento teórico; boa } \\
\text { didática. }\end{array}$ & $\begin{array}{lr}\text { O professor conhece o } \\
\text { conteúdo, mas tem } \\
\text { dificuldade na sua } \\
\text { didática. }\end{array}$ \\
\hline 021 & $\begin{array}{l}\text { Considerar a sua disciplina a mais } \\
\text { importante. }\end{array}$ & $\begin{array}{l}\text { Estímulo para pesquisa; partilhar } \\
\text { com os alunos as conquistas; } \\
\text { incentivar a busca pelo aluno. }\end{array}$ & $\begin{array}{l}\text { Não respeitar o "saber" } \\
\text { do aluno. }\end{array}$ \\
\hline 022 & $\begin{array}{l}\text { Possui conhecimento sobre a disciplina e } \\
\text { desenvolve seu trabalho de forma que os } \\
\text { alunos apreendam o conteúdo sabendo } \\
\text { onde aplicá-lo. }\end{array}$ & $\begin{array}{l}\text { Não trabalhar a Geografia de } \\
\text { forma isolada, mas trazendo-a } \\
\text { para o contexto histórico, } \\
\text { atentando-se para o } \\
\text { desenvolvimento de habilidades } \\
\text { inerentes à disciplina. }\end{array}$ & $\begin{array}{l}\text { Fragmentar } r \text { os } \\
\text { conteúdos } \\
\text { da }\end{array}$ \\
\hline 023 & $\begin{array}{l}\text { O bom professor de Geografia é aquele que } \\
\text { faz com que o aluno compreenda que fatos } \\
\text { sociais se dão dentro de um espaço } \\
\text { geográfico; ensina-o a utilizar ferramentas } \\
\text { de localização, observar e reconhecer } \\
\text { características do seu espaço. }\end{array}$ & $\begin{array}{l}\text { Observação do espaço geográfico } \\
\text { no qual o aluno está inserido; } \\
\text { utilização de recursos de } \\
\text { localização, físicos e virtuais entre } \\
\text { outras. }\end{array}$ & $\begin{array}{l}\text { Um dos equívocos mais } \\
\text { comuns é pensar na } \\
\text { Geografia como mera } \\
\text { localização de lugares, } \\
\text { estados, Capitais, } \\
\text { "confinados" em sala. }\end{array}$ \\
\hline 024 & $\begin{array}{l}\text { Professor que ouve seus alunos, identifica o } \\
\text { que não sabem e traz o saber "científico" } \\
\text { para o cotidiano do aluno. }\end{array}$ & $\begin{array}{l}\text { Aprendizagem com materiais } \\
\text { concretos (mapas, vídeos) }\end{array}$ & $\begin{array}{l}\text { Aulas penas expositivas } \\
\text { com leituras, exercícios } \\
\text { e prova. }\end{array}$ \\
\hline 025 & $\begin{array}{l}\text { Conhecimento teórico; saber a prática; } \\
\text { relacionamento. }\end{array}$ & $\begin{array}{l}\text { Considerar as aprendizagens dos } \\
\text { alunos. }\end{array}$ & $\begin{array}{l}\text { Não saber ensinar na } \\
\text { prática. }\end{array}$ \\
\hline 026 & $\begin{array}{l}\text { Fazer uma boa relação entre a Geografia } \\
\text { Humana, Física; mediar a aprendizagem dos } \\
\text { alunos através de contextualizações } \\
\text { significativas para o aluno. }\end{array}$ & $\begin{array}{l}\text { Quando trabalha com os } \\
\text { conteúdos da geografia } \\
\text { desenvolvendo habilidades que } \\
\text { permitem ao aluno se apropriar } \\
\text { de outros conhecimentos; } \\
\text { relaciona fatos importantes aos } \\
\text { lugares estudados. }\end{array}$ & $\begin{array}{l}\text { Deixar de explorar } \\
\text { mapas; trabalhar de } \\
\text { forma fragmentada a } \\
\text { Geografia Humana e a } \\
\text { Física. }\end{array}$ \\
\hline
\end{tabular}




\begin{tabular}{|c|c|c|c|}
\hline 027 & $\begin{array}{l}\text { Domina conteúdos e sabe articular de forma } \\
\text { sociointeracionista. }\end{array}$ & $\begin{array}{l}\text { Uso dos procedimentos } \\
\text { metodológicos, aulas dinâmicas, } \\
\text { uso de recursos materiais } \\
\text { (mapas...) }\end{array}$ & $\begin{array}{l}\text { Prática tradicional } \\
\text { (texto-questionário) }\end{array}$ \\
\hline 028 & $\begin{array}{l}\text { Dinâmico, criativo que traga aspectos da } \\
\text { geografia para a realidade dos alunos. }\end{array}$ & Contextualização & $\begin{array}{l}\text { Explorar apenas } \\
\text { aspectos teóricos da } \\
\text { Geografia sem articular } \\
\text { com a vida. }\end{array}$ \\
\hline 029 & Mediador; articulador; sociointeracionista. & $\begin{array}{l}\text { Que o professor tenha uma } \\
\text { postura de agente mediador e } \\
\text { articulador na aprendizagem do } \\
\text { aluno. }\end{array}$ & $\begin{array}{l}\text { Localizar os paises no } \\
\text { mapa em branco. }\end{array}$ \\
\hline 030 & $\begin{array}{l}\text { Que explora de forma prática e } \\
\text { contextualizada, tanto a Geografia Física } \\
\text { como a Política. }\end{array}$ & $\begin{array}{l}\text { Trabalhar com a prática e com } \\
\text { atualidades. }\end{array}$ & $\begin{array}{l}\text { Ficar preso a fotos, } \\
\text { mapas contidos nos } \\
\text { livros. }\end{array}$ \\
\hline 031 & $\begin{array}{l}\text { Professor mediador partindo da realidade do } \\
\text { aluno, que ensine leitura de mundo. }\end{array}$ & $\begin{array}{l}\text { Utilização de mapas; ser aberto } \\
\text { ao diálogo; bom relacionamento } \\
\text { com os alunos. }\end{array}$ & $\begin{array}{l}\text { Entregar mapas em } \\
\text { branco para os alunos } \\
\text { colocarem nomes. }\end{array}$ \\
\hline 032 & Professor pesquisador. & $\begin{array}{l}\text { Atividades extra-classe; pesquisa } \\
\text { de campo. }\end{array}$ & $\begin{array}{l}\text { Questionários fechados } \\
\text { como instrumentos de } \\
\text { avaliação; "Chamada } \\
\text { oral" dos Estados e suas } \\
\text { capitais. }\end{array}$ \\
\hline 033 & $\begin{array}{l}\text { Aquele professor que consegue trazer para a } \\
\text { realidade do aluno os fatos que ocorrem no } \\
\text { mundo/ sociedade. }\end{array}$ & $\begin{array}{l}\text { Permitir a ação do aluno, } \\
\text { apresentando para ele a sua ação } \\
\text { no mundo/ sociedade. }\end{array}$ & $\begin{array}{l}\text { Acreditar que ele é o } \\
\text { único detentor do } \\
\text { saber. }\end{array}$ \\
\hline 034 & $\begin{array}{l}\text { Articulador; que domine o conteúdo; } \\
\text { atualizado; que crie situações de } \\
\text { aprendizagem; domínio de tecnologia. }\end{array}$ & $\begin{array}{l}\text { Relacionar o conteúdo estudado } \\
\text { ao cotidiano; vivenciar situações } \\
\text { possíveis ao astudar } \\
\text { determinados conteúdos; partir } \\
\text { de situações problema para } \\
\text { construção de conceitos. }\end{array}$ & $\begin{array}{lr}\text { Priorizar } & \text { a } \\
\text { Memorização/ não } & \text { nalorizar } \\
\text { aprendizagem } & \text { dos } \\
\text { alunos; utilizar material } \\
\text { didático como único } \\
\text { recursos no processo } \\
\text { de } \\
\text { aprendizagem; } \\
\text { minimiza ensino- } \\
\text { procedimentos } \\
\text { metodológicos. }\end{array}$ \\
\hline 035 & $\begin{array}{l}\text { Saber trabalhar as diferentes linguagens; } \\
\text { professor leitor. }\end{array}$ & $\begin{array}{l}\text { Utilização de diferentes } \\
\text { estratégias. }\end{array}$ & $\begin{array}{l}\text { Ensinar } \quad \text { Geografia } \\
\text { somente com lousa e } \\
\text { giz. }\end{array}$ \\
\hline
\end{tabular}

\begin{tabular}{|c|c|c|c|}
\hline & \multicolumn{3}{|c|}{$\begin{array}{c}\text { Percepções dos Coordenadores Pedagógicos (CP) acerca da prática docente dos professores } \\
\text { de Geografia da Rede Escolar SESI-SP }\end{array}$} \\
\hline & \multicolumn{3}{|c|}{ (Grupo 05) } \\
\hline CP & $\begin{array}{l}01 \text { - O que caracteriza um bom } \\
\text { professor de Geografia }\end{array}$ & $\begin{array}{l}02 \text { - Que ações [do professor de } \\
\text { Geografia] mais contribuem para a } \\
\text { aprendizagem dos alunos? }\end{array}$ & $\begin{array}{ll}03 \quad \text { Q Quais } & \text { os } \\
\text { equívocos } & \text { mais } \\
\text { comuns na prática dos } \\
\text { professores } \\
\text { Geografia]? }\end{array}$ \\
\hline 001 & $\begin{array}{l}\text { Aquele que facilita a aprendizagem } \\
\text { do aluno atuando como mediador } \\
\text { em uma relação de ensino- } \\
\text { aprendizagem. }\end{array}$ & $\begin{array}{l}\text { Fazer o aluno pensar, discutir e, entender } \\
\text { os propósitos da geografia no contexto } \\
\text { escolar e histórico; O aluno deve "pensar" } \\
\text { a geografia. }\end{array}$ & $\begin{array}{l}\text { Achar que o aluno } \\
\text { aprende ofertando } \\
\text { textos e questões de } \\
\text { localização } \\
\text { informações. }\end{array}$ \\
\hline
\end{tabular}




\begin{tabular}{|c|c|c|c|}
\hline 002 & $\begin{array}{l}\text { Comprometido; contextualizador; } \\
\text { idealizador; boas relações humanas; } \\
\text { mediador; conhecedor. }\end{array}$ & $\begin{array}{l}\text { Planejamento relevante; tornar o } \\
\text { conteúdo significante; trabalho de campo; } \\
\text { adequação do espaço; recursos e } \\
\text { materiais bem utilizados; }\end{array}$ & $\begin{array}{ll}\text { Mais do meso; } \\
\text { professor } & \\
\text { desmotivado. } & \text { Aulas } \\
\text { sem sequência. } & \\
\end{array}$ \\
\hline 003 & $\begin{array}{l}\text { Aquele que consegue criar boas } \\
\text { situações de aprendizagem } \\
\text { mobilizando o aluno a aprender. }\end{array}$ & $\begin{array}{l}\text { Vivências (observação), pesquisa, debate, } \\
\text { leitura e interpretação, tendo o professor } \\
\text { por mediador do processo ensino } \\
\text { aprendizagem. }\end{array}$ & $\begin{array}{l}\text { Que aula expositiva } \\
\text { não é uma boa aula, ou } \\
\text { achar que o aluno não } \\
\text { sabe ou já deveria } \\
\text { saber. }\end{array}$ \\
\hline 004 & $\begin{array}{l}\text { Atualização (dos conhecimentos); } \\
\text { Dinamismo; Didática adequada à } \\
\text { faixa etária. }\end{array}$ & $\begin{array}{l}\text { A principal eu acredito que é a de perceber } \\
\text { o mundo em que vivemos e suas } \\
\text { modificações. }\end{array}$ & $\begin{array}{l}\text { Trabalhar fatos } \\
\text { isolados, desconexos. }\end{array}$ \\
\hline 005 & 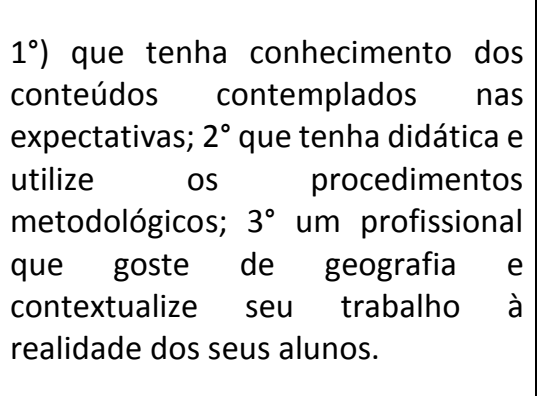 & $\begin{array}{l}\text { Estudo do meio, a través de visitas } \\
\text { monitoradas; Pesquisas; Trabalho; } \\
\text { trabalho integrado aos outros } \\
\text { componentes curriculares (história, LP, } \\
\text { Arte, Matemática, etc.); Utilizar recursos } \\
\text { diversificados para ministrar uma boa } \\
\text { aula. }\end{array}$ & $\begin{array}{l}\text { Achar que os alunos } \\
\text { devem decorar nomes } \\
\text { de paises, rios, } \\
\text { oceanos, rem } \\
\text { contextualizar seus } \\
\text { conhecimentos. Não } \\
\text { levar em conta os } \\
\text { conhecimentos prévios } \\
\text { dos alunos. }\end{array}$ \\
\hline 006 & $\begin{array}{l}\text { Conhecer o conteúdo; trabalhar com } \\
\text { as expectativas; ser um mediador. }\end{array}$ & Trabalhar com pesquisas; ser dinâmico. & $\begin{array}{lr}\text { Trabalhar } r & \text { fatos } \\
\text { isolados; trabalhar } & \text { somente com textos } \\
\text { (ele não aprende } \\
\text { geografia); }\end{array}$ \\
\hline 007 & $\begin{array}{l}\text { Gostar da área; ter entusiasmo; } \\
\text { aulas dinâmicas e significativas para } \\
\text { os alunos. }\end{array}$ & $\begin{array}{l}\text { Trabalhar diferentes recursos como } \\
\text { mapas, mídias, usar recursos da biblioteca } \\
\text { e informática; pesquisa de campo. }\end{array}$ & $\begin{array}{l}\text { Falta de } \\
\text { contextualização; aulas } \\
\text { expositivas; }\end{array}$ \\
\hline 008 & Professor pesquisador. & Onde há interação entre aluno e professor. & $\begin{array}{l}\text { Nas atividades que } \\
\text { envolvem mapas } \\
\text { (pintar os paises, etc.) }\end{array}$ \\
\hline 009 & $\begin{array}{l}\text { Domina os conteúdos; desenvolve o } \\
\text { ensino através dos procedimentos } \\
\text { metodológicos; tem uma boa } \\
\text { relação interpessoal. }\end{array}$ & $\begin{array}{l}\text { Utilização de diversos recursos; utilização } \\
\text { dos espaços da escola. }\end{array}$ & $\begin{array}{l}\text { Aulas expositivas; } \\
\text { monotonia em todas } \\
\text { as aulas; }\end{array}$ \\
\hline 010 & $\begin{array}{l}\text { O professor motivado que reflete } \\
\text { sobre sua ação, buscando sempre } \\
\text { boas práticas de ensino que levem o } \\
\text { aluno a aprender. }\end{array}$ & $\begin{array}{l}\text { Estudos do meio/ de campo; pesquisas } \\
\text { bem orientadas; utilize as TIC e aplicativos; } \\
\text { mapas; leitura de imagens; produção de } \\
\text { maquetes. }\end{array}$ & \begin{tabular}{|lr} 
aulas & somente \\
expositivas; não ouvir \\
os alunos; avaliações \\
que não & sejam \\
processuais & e \\
formativas; & \\
\end{tabular} \\
\hline 011 & $\begin{array}{l}\text { Aquele atento aos acontecimentos } \\
\text { do dia-a-dia fazendo relações com o } \\
\text { estudo em questão e questionador. }\end{array}$ & $\begin{array}{l}\text { Questionar; ouvir opiniões; levantar } \\
\text { conhecimentos prévios; problematizar; } \\
\text { construir com o aluno. }\end{array}$ & $\begin{array}{l}\text { Se apóia somente no } \\
\text { livro; questionário e } \\
\text { explicações. }\end{array}$ \\
\hline 012 & $\begin{array}{l}\text { Formação, aplicação das teorias; } \\
\text { vivências em localizar, identificar; } \\
\text { reconhecer as dificuldades dos } \\
\text { alunos e propor atividades para } \\
\text { avanço. }\end{array}$ & $\begin{array}{l}\text { Levantamento de conhecimentos e } \\
\text { atuação nos não saberes em saberes com } \\
\text { entusiasmo. }\end{array}$ & $\begin{array}{l}\text { Generalizar as } \\
\text { dificuldades e pensar } \\
\text { que o aluno já venha } \\
\text { "pronto" }\end{array}$ \\
\hline
\end{tabular}




\begin{tabular}{|c|c|c|c|}
\hline 013 & $\begin{array}{l}\text { Aquele que favorece o aluno na } \\
\text { construção de seus saberes, } \\
\text { possibilitando meios que despertem } \\
\text { no aluno o interesse pela } \\
\text { aprendizagem. }\end{array}$ & $\begin{array}{l}\text { Oportunizar a experiência ou checagem } \\
\text { dos temas trabalhados. }\end{array}$ & $\begin{array}{l}\text { Acreditar que o aluno } \\
\text { "tem que saber", ou } \\
\text { considerar que tal } \\
\text { conhecimento é óbvio. }\end{array}$ \\
\hline 014 & $\begin{array}{l}\text { Tenha paixão pela geografia; estar } \\
\text { sempre se aprimorando; motive os } \\
\text { alunos. }\end{array}$ & $\begin{array}{l}\text { Aproximar os conteúdos à realidade do } \\
\text { aluno; desenvolver as habilidades. }\end{array}$ & $\begin{array}{lr}\text { Ser } & \text { somente } \\
\text { transmissor de } \\
\text { conhecimento; não ter } \\
\text { a prática dialógica; não } \\
\text { ouvir o aluno. }\end{array}$ \\
\hline 015 & $\begin{array}{l}\text { O conhecimento e a forma como } \\
\text { apresenta esse conteúdo/ } \\
\text { conhecimento aos alunos. }\end{array}$ & $\begin{array}{l}\text { A identificação da aprendizagem no } \\
\text { cotidiano. }\end{array}$ & $\begin{array}{l}\text { Práticas expositivas, } \\
\text { sem o envolvimento } \\
\text { dos alunos; limitar o } \\
\text { conhecimento nos } \\
\text { registros dos livros. }\end{array}$ \\
\hline 016 & $\begin{array}{l}\text { Utilização de recursos didáticos e } \\
\text { tecnológicos; } \quad \text { atualização } \\
\text { profissional, espírito de } \\
\text { pesquisador; aulas dinâmicas com } \\
\text { pesquisa de campo e observação. }\end{array}$ & $\begin{array}{l}\text { Levá-los a observar e realiza trabalhos de } \\
\text { campo; pesquisas sobre assuntos atuais; } \\
\text { utilização de mapas; recursos didáticos e } \\
\text { TIC's para contextualizar e significar a aula. }\end{array}$ & $\begin{array}{l}\text { Aula puramente } \\
\text { expositiva; abordagem } \\
\text { fragmentada dos } \\
\text { conteúdos, não há } \\
\text { interdisciplinaridade. }\end{array}$ \\
\hline 017 & $\begin{array}{l}\text { Utiliza recursos tecnológicos; } \\
\text { atualização; utilizar-se de mapas, } \\
\text { contextualizar os conteúdos. }\end{array}$ & $\begin{array}{l}\text { Observação, trabalho de campo; } \\
\text { contextualizar; prática, produção. }\end{array}$ & $\begin{array}{l}\text { Abordagem de } \\
\text { conteúdos } \\
\text { fragmentados; aula } \\
\text { somente expositiva. } \\
\end{array}$ \\
\hline 018 & $\begin{array}{l}\text { Disponibilidade; interação com o } \\
\text { aluno; professor atualizado/ } \\
\text { antenado. }\end{array}$ & $\begin{array}{l}\text { Participação ativa dos alunos; interesse na } \\
\text { própria formação do professor., }\end{array}$ & $\begin{array}{l}\text { não ouvir os alunos, } \\
\text { não partir dos } \\
\text { conhecimentos } \\
\text { prévios; preocupação } \\
\text { grande somente na } \\
\text { sistematização e não } \\
\text { nos outros } \\
\text { procedimentos. }\end{array}$ \\
\hline 019 & $\begin{array}{l}\text { Dinâmico, crítico. Deve aproximar os } \\
\text { conteúdos estudados ao cotidiano } \\
\text { dos alunos. }\end{array}$ & $\begin{array}{l}\text { Partir do cotidiano para chegar aos } \\
\text { conceitos; } \\
\text { interdisciplinarmente. }\end{array}$ & $\begin{array}{l}\text { Manter a geografia } \\
\text { distante do cotidiano } \\
\text { dos alunos; ater-se } \\
\text { demais a livro e textos. }\end{array}$ \\
\hline 020 & $\begin{array}{l}\text { Aquele que faz o aluno pensar, } \\
\text { através da mediação. }\end{array}$ & $\begin{array}{l}\text { Solicitar a pesquisa e transformá-la em } \\
\text { fonte de aprendizagem. }\end{array}$ & $\begin{array}{l}\text { dar textos para leitura } \\
\text { e cobrar o conteúdo } \\
\text { sem contextualização. }\end{array}$ \\
\hline 021 & $\begin{array}{l}\text { Utilização de recursos diversos; } \\
\text { atualização; consegue relacionar a } \\
\text { Geografia às questões históricas e } \\
\text { significativas para os alunos. }\end{array}$ & $\begin{array}{l}\text { Atividades que relacionem a geografia } \\
\text { com as questões do dia-a-dia dos alunos; } \\
\text { trabalho de campo que envolva o entorno } \\
\text { do aluno; }\end{array}$ & $\begin{array}{l}\text { aulas expositivas e } \\
\text { mecânicas; não } \\
\text { reflexão sobre sua } \\
\text { realidade local (aluno). }\end{array}$ \\
\hline 022 & $\begin{array}{l}\text { Conhecer o seu conteúdo e aprender } \\
\text { a cada dia. }\end{array}$ & Ser dinâmico e levar os alunos a aprender; & $\begin{array}{l}\text { Trabalhar fatos } \\
\text { isolados; decorar. }\end{array}$ \\
\hline 023 & $\begin{array}{l}\text { O que consegue transitar pelas } \\
\text { diversas linguagens do componente } \\
\text { explorando a cartografia, o espaço, a } \\
\text { política, os lugares e todo o } \\
\text { dinamismo da atualidade, com a } \\
\text { intervenção humana. }\end{array}$ & $\begin{array}{l}\text { O professor que consegue realizar a } \\
\text { transposição didática e tornar esta } \\
\text { geografia significativa, levar o aluno a } \\
\text { perceber que quem transforma o espaço } \\
\text { (lugar) é o homem. }\end{array}$ & $\begin{array}{l}\text { Fazer listas de países e } \\
\text { capitais para os alunos } \\
\text { decorarem; decorar } \\
\text { mapas, nomes de } \\
\text { reios, etc... como se o } \\
\text { homem não } \\
\text { interviesse em tudo } \\
\text { isto. }\end{array}$ \\
\hline
\end{tabular}




\begin{tabular}{|c|c|c|c|}
\hline 024 & $\begin{array}{l}\text { Ser atualizado, dinâmico (utilizar } \\
\text { diversos recursos e espaços...) }\end{array}$ & $\begin{array}{l}\text { Compreensão de leituras, textos diversos, } \\
\text { inclusive imagens. }\end{array}$ & $\begin{array}{l}\text { Solicitar aos alunos que } \\
\text { pintem mapas. }\end{array}$ \\
\hline 025 & $\begin{array}{l}\text { Proporcionar para o aluno } \\
\text { instrumentos que desenvolvam e } \\
\text { ampliem o seu olhar do mundo. }\end{array}$ & $\begin{array}{l}\text { Possibilitar ao aluno a reflexão sobre os } \\
\text { fatos e fenômenos da natureza, através de } \\
\text { questionamentos que levem o aluno a } \\
\text { pensar. }\end{array}$ & $\begin{array}{l}\text { Achar que o aluno e os } \\
\text { conhecimentos } \\
\text { escolares estão fora do } \\
\text { contexto da vida } \\
\text { cotidiana. }\end{array}$ \\
\hline 026 & $\begin{array}{l}\text { Domínio de "conteúdo"; pesquisa } \\
\text { constantemente relacionando fatos } \\
\text { atuais; crítico em relação à política } \\
\text { atual; inova e reflete perante a sua } \\
\text { prática; pratica auto-avaliação. }\end{array}$ & $\begin{array}{l}\text { Relacionar o "conteúdo" com a realidade } \\
\text { local do aluno; diversificar as estratégias } \\
\text { de aprendizagem (poemas, músicas, } \\
\text { vídeos, charges); promover "estudo do } \\
\text { meio" }\end{array}$ & $\begin{array}{lll}\text { Separação entre a } & \text { física e } \\
\text { geografia } & \text { fílização } \\
\text { humana; } & \text { utilia } \\
\text { excessiva da aula } \\
\text { expositiva. }\end{array}$ \\
\hline 027 & $\begin{array}{l}\text { Estar atualizado e mediar os } \\
\text { conhecimentos com os alunos } \\
\text { (aluno<=> professor); trabalhar } \\
\text { atividades em que os alunos } \\
\text { participem ativamente do processo } \\
\text { de ensino-aprendizagem. }\end{array}$ & $\begin{array}{l}\text { Explanação com significado; participação } \\
\text { ativa dos alunos; estimular a curiosidade e } \\
\text { a investigação; trazer assuntos atuais para } \\
\text { fazer intercâmbios com as expectativas. }\end{array}$ & $\begin{array}{l}\text { "Achar" que algumas } \\
\text { atividades práticas não } \\
\text { são significativas e } \\
\text { portanto não trabalhar } \\
\text { com elas; limitar-se em } \\
\text { livros/ apostila. }\end{array}$ \\
\hline 028 & $\begin{array}{l}\text { Recursos didáticos diversos; } \\
\text { recursos tecnológicos; atualizado, } \\
\text { que saiba contextualizar suas aulas } \\
\text { com os assuntos atuais; aula } \\
\text { dinâmica/ compreensão do } \\
\text { conteúdo. }\end{array}$ & $\begin{array}{l}\text { Aulas dinâmicas, contextualizadas, com } \\
\text { recursos didáticos diversos; professor que } \\
\text { encante os alunos com a geografia (o seu } \\
\text { próprio encantamento com a disciplina } \\
\text { que leciona). }\end{array}$ & $\begin{array}{l}\text { Aulas somente } \\
\text { expositivas; conteúdos } \\
\text { descontextualizados, } \\
\text { fragmentados. }\end{array}$ \\
\hline 029 & $\begin{array}{l}\text { Aquele que consegue ensinar a } \\
\text { leitura das diversas linguagens do } \\
\text { componente curricular; realiza a } \\
\text { transposição didática. }\end{array}$ & $\begin{array}{l}\text { O professor deve ensinar a transposição } \\
\text { didática relacionar o conteúdo com a } \\
\text { realidade. }\end{array}$ & $\begin{array}{l}\text { Achar que o aluno } \\
\text { compreende da } \\
\text { mesma maneira que } \\
\text { ele, que já vivenciou as } \\
\text { situações. "O que está } \\
\text { óbvio para o professor } \\
\text { pode não ser par o } \\
\text { aluno". }\end{array}$ \\
\hline 030 & $\begin{array}{l}\text { Que faz uma clara e eficaz } \\
\text { contextualização, trazendo a } \\
\text { atualidade para sala de aula. }\end{array}$ & $\begin{array}{l}\text { Aguçar a curiosidade; trabalho com o } \\
\text { lúdico; contextualizar. }\end{array}$ & "Decc \\
\hline 031 & $\begin{array}{l}\text { Quando constrói com o aluno uma } \\
\text { análise crítica da sua realidade, a } \\
\text { partir da sua localização geográfica e } \\
\text { suas relações com o mundo. }\end{array}$ & $\begin{array}{l}\text { Ações em que o aluno tenha experiências } \\
\text { mais próximas da realidade, de forma a } \\
\text { refletir sobre a ocupação humana dos } \\
\text { espaços, de seus usos e costumes. }\end{array}$ & $\begin{array}{lr}\text { Trabalhar o conteúdo } \\
\text { de forma } & \text { mecânica; } \\
\text { valorizar } & \text { a } \\
\text { memorização } & \text { em } \\
\text { detrimento } & \text { da } \\
\text { reflexão; } & \text { pouca } \\
\text { utilização } & \text { de } \\
\text { linguagens variadas. }\end{array}$ \\
\hline 032 & $\begin{array}{l}\text { Conhecimento do conteúdo; ensino } \\
\text { dialogado; contextualização com } \\
\text { atualidades, etc. }\end{array}$ & $\begin{array}{l}\text { Fazer análises, comparações e conclusões; } \\
\text { manusear diferentes materiais em } \\
\text { diferentes contextos (jornais...) }\end{array}$ & $\begin{array}{l}\text { Distanciar-se das } \\
\text { atualidades e trabalhar } \\
\text { apenas com fatos } \\
\text { históricos pontuais. }\end{array}$ \\
\hline 033 & $\begin{array}{l}\text { Que trabalhe com o lúdico. Com } \\
\text { bons textos da atualidade. }\end{array}$ & $\begin{array}{l}\text { Bons textos; trabalhar com mapas, } \\
\text { músicas; trabalhar com interpretação de } \\
\text { gráficos e tabelas. }\end{array}$ & Fazer o aluno decorar. \\
\hline
\end{tabular}

Percepções dos Coordenadores Pedagógicos (CP) acerca da prática docente dos professores de Geografia da Rede Escolar SESI-SP 


\begin{tabular}{|c|c|c|c|}
\hline & \multicolumn{3}{|c|}{ (Grupo 06) } \\
\hline $\mathbf{C P}$ & $\begin{array}{l}01 \text { - } 0 \text { que caracteriza um bom } \\
\text { professor de Geografia }\end{array}$ & $\begin{array}{l}02 \text { - Que ações [do professor } \\
\text { de Geografia] r mais } \\
\text { contribuem para a } \\
\text { aprendizagem dos alunos? }\end{array}$ & $\begin{array}{l}03 \text { - Quais os equívocos mais } \\
\text { comuns na prática dos } \\
\text { professores [de Geografia]? }\end{array}$ \\
\hline 001 & $\begin{array}{l}\text { Dominar o assunto; ter boa didática, } \\
\text { respeitar o aluno. }\end{array}$ & $\begin{array}{l}\text { Quando as aulas são } \\
\text { diversificadas e despertam o } \\
\text { interesse do aluno }\end{array}$ & $\begin{array}{l}\text { Acreditar que o aluno que } \\
\text { decora está levando } \\
\text { conhecimento: } \\
\text { Não conhecer o aluno. }\end{array}$ \\
\hline 002 & Domínio do conteúdo;Boa didática; & Diversificação das aulas. & $\begin{array}{l}\text { Rotular } \quad \text { o aluno; } \\
\text { Acreditar na "decoreba" }\end{array}$ \\
\hline 003 & $\begin{array}{l}\text { Domínio do conteúdo;Boa didática } \\
\text { (saber transmitir/ utilizar recursos);; }\end{array}$ & Diversificação das aulas & \begin{tabular}{|l} 
Rotular $\quad$ o aluno; \\
Acreditar na "decoreba"
\end{tabular} \\
\hline 004 & $\begin{array}{l}\text { O professor que organiza suas aulas, que } \\
\text { está sempre pesquisando e articulando } \\
\text { com os alunos. } \\
\text { Realiza processo ensino aprendizagem. }\end{array}$ & $\begin{array}{l}\text { Trabalho de pesquisa, } \\
\text { observação, pesquisa de } \\
\text { campo, debates e seminários. }\end{array}$ & $\begin{array}{l}\text { Os objetivos da Geografia } \\
\text { (decorar, memorizar) }\end{array}$ \\
\hline 005 & $\begin{array}{l}\text { O que faz articulação da Geografia com } \\
\text { outros componentes curriculares e com } \\
\text { o cotidiano. }\end{array}$ & $\begin{array}{l}\text { O uso de estratégias e recursos } \\
\text { pedagógicos diversificados. }\end{array}$ & $\begin{array}{l}\text { Dar mais ênfase à geografia } \\
\text { física. } \\
\text { Não trabalhar questões } \\
\text { operatórias; } \\
\text { Usar com pouca frequência os } \\
\text { recursos pedagógicos } \\
\text { disponíveis nas unidades. }\end{array}$ \\
\hline 006 & $\begin{array}{l}\text { Ser dinâmico durante as aulas; } \\
\text { Atualizado; } \\
\text { Ter domínio do conteúdo e saber ver no } \\
\text { estudo as habilidades e competências } \\
\text { do componente; } \\
\text { Trabalhar de forma centrada no fazer do } \\
\text { alunos. }\end{array}$ & $\begin{array}{l}\text { Planejar aulas equilibrando o } \\
\text { uso da leitura, de recursos } \\
\text { didáticos, exposição oral e } \\
\text { fazer do aluno; } \\
\begin{array}{l}\text { Estimular a pesquisa e a } \\
\text { curiosidade. }\end{array}\end{array}$ & $\begin{array}{l}\text { Entrar em sala de aula para ler, } \\
\text { falar e pedir para que o aluno } \\
\text { responda aos exercícios. }\end{array}$ \\
\hline 007 & $\begin{array}{l}\text { Domínio dos procedimentos } \\
\text { metodológicos; } \\
\text { Domínio dos conteúdos de sua área; } \\
\text { Conhecimento da proposta da Rede SEI } \\
\text {-SP; }\end{array}$ & $\begin{array}{l}\text { aulas bem estruturadas dentro } \\
\text { dos procedimentos } \\
\text { metodológicos. }\end{array}$ & $\begin{array}{l}\text { Dificuldade de explorar os } \\
\text { procedimentos metodológicos } \\
\text { no plano docente e nas aulas. }\end{array}$ \\
\hline 008 & $\begin{array}{l}\text { Ter domínio do conteúdo e aplicação de } \\
\text { técnicas motivadoras } \\
\text { Ser articulador. }\end{array}$ & \begin{tabular}{|lr} 
Aulas & motivadoras; \\
Utilizar recursos que garantam \\
a aprendizagem $\quad$ (aulas \\
diversificadas).
\end{tabular} & $\begin{array}{l}\text { Avaliação coerente com a } \\
\text { prática e teoria. ( Avaliação do } \\
\text { processo). }\end{array}$ \\
\hline 009 & $\begin{array}{l}\text { Dominar conteúdo; } \\
\text { Habilidade para estabelecer conexões } \\
\text { com outros saberes ou fatores } \\
\text { históricos; } \\
\text { mediador/ problematizador }\end{array}$ & 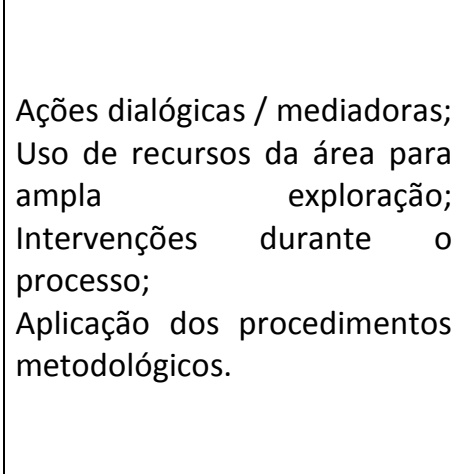 & $\begin{array}{l}\text { Desconsiderar as dimensões } \\
\text { de avaliação: diagnóstica e } \\
\text { formativa no processo de } \\
\text { ensino - aprendizagem. } \\
\text { Realizações de intervenções } \\
\text { no final do tratamento dos } \\
\text { conteúdos (recuperação); } \\
\text { Relevância para os conteúdos } \\
\text { desconsiderando habilidades e } \\
\text { competências explicitados nas } \\
\text { expectativas. }\end{array}$ \\
\hline
\end{tabular}




\begin{tabular}{|c|c|c|c|}
\hline 010 & $\begin{array}{l}\text { Aquele que tem domínio do conteúdo e } \\
\text { sabe transmitir -lo, que utiliza diferentes } \\
\text { recursos pedagógicos. }\end{array}$ & $\begin{array}{l}\text { Diversidade de estratégias e } \\
\text { recursos } \\
\text { Relacionar os codagógicos; } \\
\text { ensinados com que irá ensinar. }\end{array}$ & $\begin{array}{l}\text { Memorização do conteúdo; } \\
\text { utilização somente do material } \\
\text { didático ( não diversificar os } \\
\text { recursos didáticos } \\
\text { pedagógicos e estratégias do } \\
\text { ensino. }\end{array}$ \\
\hline 011 & $\begin{array}{lr}\text { Dinâmico;Dominem } & \text { os } \\
\text { conteúdos;Relacionem } & \text { os } \\
\text { conhecimentos à vida cotidiana;mostre } \\
\text { significados. }\end{array}$ & $\begin{array}{|lr|}\text { Aulas dinâmicas; } & \text { Diversos } \\
\text { recursos;Trabalhor com } \\
\text { pesquisa;Atividades } \\
\text { interdisciplinares. }\end{array}$ & $\begin{array}{l}\text { Acreditar que a Rede é } \\
\text { "proibido" "decorar" = } \\
\text { memorizar;Avaliação distante } \\
\text { da realidade. }\end{array}$ \\
\hline 012 & $\begin{array}{l}\text { Domínio } \\
\text { Didática para } \\
\text { conteúdo. }\end{array}$ & $\begin{array}{l}\text { Em Geografia material onde } \\
\text { façam aprender localizar e para } \\
\text { isso usar diferentes } \\
\text { estratégias. } \\
\text { Uso de diferentes recursos. }\end{array}$ & $\begin{array}{l}\text { Didática, a forma como passo o } \\
\text { conteúdo. } \\
\text { Inovar as maneiras de dar aula. } \\
\text { Forma de tratar os alunos. }\end{array}$ \\
\hline 013 & 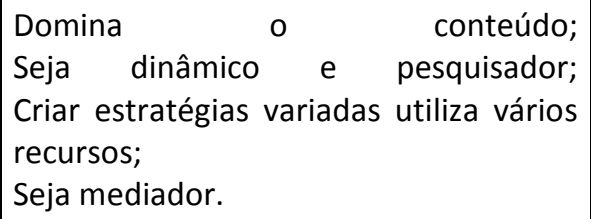 & $\begin{array}{l}\text { Acompanhamento mais } \\
\text { individualizado; } \\
\text { Diversificar as atividades. }\end{array}$ & $\begin{array}{l}\text { Não identificar o conteúdo e as } \\
\text { habilidades/ competências das } \\
\text { expectativas. }\end{array}$ \\
\hline 014 & $\begin{array}{l}\text { Aquele que é mediador; } \\
\text { Que sabe contextualizar o conteúdo } \\
\text { trazendo para o que aluno conhece } \\
\text { (mundo); } \\
\text { Articular saberes. }\end{array}$ & $\begin{array}{l}\text { Saber ouvir e mediar; } \\
\text { Interação; } \\
\text { Pesquisa orientada. }\end{array}$ & $\begin{array}{l}\text { Trabalhar com perguntas e } \\
\text { respostas só fechadas; } \\
\text { Rotular algum aluno; } \\
\text { Generalizar; } \\
\text { Realizar atividades para as } \\
\text { mesmas turmas e achar que há } \\
\text { o mesmo resultado. }\end{array}$ \\
\hline 015 & $\begin{array}{l}\text { Dinamismo; } \\
\text { Articulação dos saberes; } \\
\text { Contextualização; } \\
\text { Auto formação e atualização constante. }\end{array}$ & $\begin{array}{l}\text { Estabelecer conexões entre os } \\
\text { conhecimentos apreendidos; } \\
\text { Tirar o aluno do senso comum } \\
\text { na busca pelo saber } \\
\text { cientifico,utilizando material } \\
\text { manipulável, } \\
\text { necessário. }\end{array}$ & $\begin{array}{l}\text { "Parar" o ensino no conteúdo } \\
\text { pelo conteúdo e acreditar que } \\
\text { somente ele dará conta da } \\
\text { verdadeira aprendizagem do } \\
\text { aluno. }\end{array}$ \\
\hline 016 & $\begin{array}{ll}\text { Conhecimento } & \text { especifico; } \\
\text { Dinamismo; } & \\
\text { Leitor; } & \\
\text { Buscar novas } & \text { estratégias; } \\
\text { Atender os alunos. } & \end{array}$ & $\begin{array}{|lr|}\text { Observação; } & \\
\text { Análise do } & \text { erro; } \\
\text { Sustentação } & \text { dos } \\
\text { conhecimentos } & \text { adquiridos; } \\
\text { Socialização } & \text { dos } \\
\text { conhecimentos. } & \end{array}$ & $\begin{array}{l}\text { O Professor achar que a aula } \\
\text { expositiva e suficiente para a } \\
\text { aprendizagem de todos osd } \\
\text { alunos. }\end{array}$ \\
\hline 017 & $\begin{array}{l}\text { Dinâmico; } \\
\text { Mediador; } \\
\text { Conheça Geografia e saiba fazer a } \\
\text { relação Homem x sociedade x natureza. }\end{array}$ & $\begin{array}{l}\text { Utilização dos procedimentos } \\
\text { metodológicos sempre visando } \\
\text { a construção } \\
\text { conhecimento. }\end{array}$ & $\begin{array}{l}\text { Dar muita teoria e pouca } \\
\text { prática. }\end{array}$ \\
\hline 018 & $\begin{array}{l}\text { Ter um domínio do conteúdo e expor } \\
\text { sua aula usando estratégia variadas. }\end{array}$ & $\begin{array}{l}\text { Atividades diversificada para } \\
\text { melhor ser compreendido os } \\
\text { conteúdos. }\end{array}$ & $\begin{array}{l}\text { Ir para novo conteúdo sem } \\
\text { verificar se há domínio dos } \\
\text { anteriores. }\end{array}$ \\
\hline 019 & $\begin{array}{l}\text { Um professor tem que ser pesquisador, } \\
\text { orientador e observador. }\end{array}$ & $\begin{array}{l}\text { Caracterizar, trazendo para o } \\
\text { cotidiano do aluno sem } \\
\text { esquecer da teoria. }\end{array}$ & $\begin{array}{l}\text { Não perceber que a Geografia } \\
\text { está no cotidiano do professor; } \\
\text { Matéria decoreba. }\end{array}$ \\
\hline
\end{tabular}




\begin{tabular}{|c|c|c|c|}
\hline 020 & $\begin{array}{l}\text { Professor que além de ter um bom } \\
\text { domínio, utiliza-se de meios / recursos } \\
\text { adequados, contextualizando } \\
\text { interagindo. }\end{array}$ & $\begin{array}{l}\text { Ações diferenciadas de } \\
\text { intervenções, inferências. }\end{array}$ & $\begin{array}{l}\text { Os de considerarem os alunos } \\
\text { não necessitam de } \\
\text { intervenção. }\end{array}$ \\
\hline 021 & $\begin{array}{l}\text { Aquele que realmente ensina com } \\
\text { prazer e propõe aulas desafiadoras. }\end{array}$ & $\begin{array}{l}\text { Quando os alunos são } \\
\text { protagonistas nas aulas (alunos } \\
\text { pesquisadores). }\end{array}$ & Aulas "GLS" - giz, lousa e saliva. \\
\hline 022 & $\begin{array}{l}\text { Conhecimento sobre sua área de } \\
\text { trabalho;Didática no trabalho em } \\
\text { relação com } \\
\text { metodológicos. }\end{array}$ & $\begin{array}{l}\text { Estratégias diversificadas; } \\
\text { Mediação e intervenção do } \\
\text { professor na interação com os } \\
\text { alunos. }\end{array}$ & $\begin{array}{l}\text { Avaliação da aprendizagem no } \\
\text { processo. }\end{array}$ \\
\hline 023 & $\begin{array}{l}\text { Planejamento para utilização de vários } \\
\text { recursos didáticos e formas } \\
\text { diferenciadas para evitar que o aluno } \\
\text { recorra a "decorar" os conteúdos. }\end{array}$ & $\begin{array}{l}\text { Atividades concretas (lúdicas), } \\
\text { pois a Geografia em alguns } \\
\text { aspectos é difícil compreensão. }\end{array}$ & $\begin{array}{l}\text { Acreditar que os alunos } \\
\text { sempre chegam com pré - } \\
\text { requisitos esperados. }\end{array}$ \\
\hline 024 & 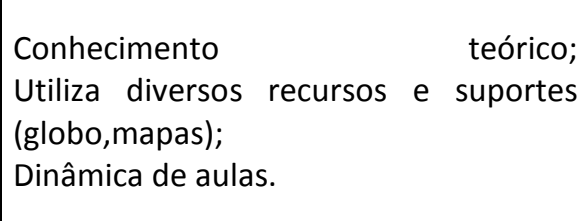 & \begin{tabular}{|lrr} 
Aulas & dinâmicas; \\
Uso & das & TIC's; \\
Diversos & & recursos; \\
Relacionar & os conteúdos com o \\
\multicolumn{2}{l}{ cotidiano. } &
\end{tabular} & $\begin{array}{l}\text { Não utilizar atividades que } \\
\text { exigem conhecimento de } \\
\text { memória; } \\
\text { Avaliação distante da prática } \\
\text { da aula. }\end{array}$ \\
\hline 025 & $\begin{array}{l}\text { Atualizado; } \\
\text { Com conhecimentos das tecnologias; } \\
\text { Domínio de conteúdo }\end{array}$ & $\begin{array}{l}\text { Desafios; } \\
\text { Olimpíadas/ } \\
\text { Pesquisas. }\end{array}$ & $\begin{array}{l}\text { Ficar no discurso, longe das } \\
\text { observações da influência da } \\
\text { Geografia na vida. }\end{array}$ \\
\hline 026 & \begin{tabular}{|lr} 
Professor & pesquisador; \\
Avaliar de formas diversificadas; \\
surpreende os alunos com proposta \\
inovadoras e práticas.
\end{tabular} & $\begin{array}{l}\text { Atividades diversificada; } \\
\text { Contextualização; } \\
\text { Interdisciplinaridade, }\end{array}$ & $\begin{array}{l}\text { É limitar o conteúdo a apenas } \\
\text { algumas habilidades das } \\
\text { expectativas.(não ir além). }\end{array}$ \\
\hline 027 & $\begin{array}{l}\text { aquele que "sabe" para que serve o } \\
\text { conhecimentos de Geografia para a vida } \\
\text { o individuou. }\end{array}$ & $\begin{array}{l}\text { Contextualizar o ensino de } \\
\text { conteúdo á necessidade de } \\
\text { aprendizado para apropriação } \\
\text { e uso do aluno. }\end{array}$ & $\begin{array}{l}\text { Trabalhar conteúdos alheios } \\
\text { aos interesses e necessidades } \\
\text { dos alunos. }\end{array}$ \\
\hline 028 & $\begin{array}{l}\text { Proporciona atividades diversificadas; } \\
\text { Interdisciplinaridade; } \\
\text { Professor pescador; }\end{array}$ & $\begin{array}{l}\text { Utilização dos processos } \\
\text { procedimentos } \\
\text { metodológicos; } \\
\text { Diferentes estratégicas }\end{array}$ & Avaliação no processo \\
\hline 029 & $\begin{array}{l}\text { Dinâmico; } \\
\text { Facilitador; } \\
\text { Propicia momentos de reflexão; } \\
\text { Observa e orienta. }\end{array}$ & 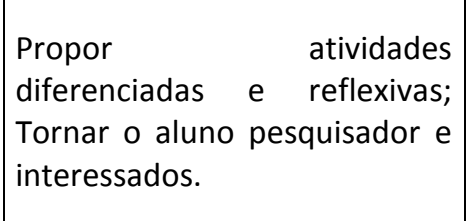 & 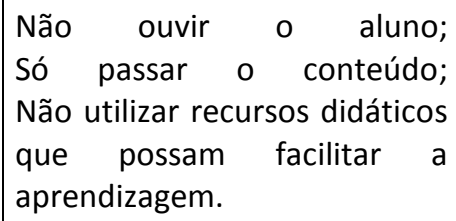 \\
\hline 030 & $\begin{array}{l}\text { Domínio } \quad \text { de } \\
\text { Ser professor articulador. }\end{array}$ & $\begin{array}{l}\text { Utilização de recursos } \\
\text { didáticos; } \\
\text { uso dos procedimentos } \\
\text { metodológicos; } \\
\text { Intervenção/ mediação. }\end{array}$ & Avaliação no processo. \\
\hline 31 & $\begin{array}{l}\text { Ser pesquisador e atualizado, além de } \\
\text { ter domínio do conteúdo; }\end{array}$ & $\begin{array}{l}\text { Envolver os alunos } \\
\text { dinâmicas propostas. }\end{array}$ & $\begin{array}{l}\text { Não desenvolver as } \\
\text { habilidades indicadas nas } \\
\text { expectativas focando apenas o } \\
\text { conteúdo. }\end{array}$ \\
\hline
\end{tabular}




\begin{tabular}{|c|c|c|c|}
\hline 32 & $\begin{array}{l}\text { Pesquisador, orienta os alunos sempre } \\
\text { que possível. } \\
\text { Deixa os alunos expor suas ideias e } \\
\text { compartilhar com a turma. }\end{array}$ & $\begin{array}{|lrr|}\text { Trabalho } & \text { com } & \text { imagens, } \\
\text { atividades } & & \text { concretas; } \\
\text { Trabalho em } & \text { grupo com } \\
\text { mediação } & \text { do } & \text { professor; } \\
\text { Pesquisas e apresentações. }\end{array}$ & $\begin{array}{l}\text { Aluno que já sabe tudo e não } \\
\text { precisa retomar o conteúdo }\end{array}$ \\
\hline 33 & $\begin{array}{l}\text { Que ele seja: mediador,facilitador, } \\
\text { dinâmico. }\end{array}$ & $\begin{array}{|lr|}\text { Acompanhamento dos alunos } \\
\text { com } & \text { dificuldades; } \\
\text { Aulas } & \text { motivadoras } \\
\text { desafiadora. } & \\
\end{array}$ & $\begin{array}{l}\text { Trabalho com atividades } \\
\text { concretas. }\end{array}$ \\
\hline 34 & $\begin{array}{l}\text { Diversificar as } \quad \text { estratégias; } \\
\text { Pesquisador; } \\
\text { Aulas bem } \\
\text { mediador. }\end{array}$ & $\begin{array}{l}\text { Aula dinâmica; } \\
\text { Atividades concretas, lúdicas; } \\
\text { Relacionar, paralelo com } \\
\text { atualidades; } \\
\text { leitura de imagens }\end{array}$ & $\begin{array}{l}\text { Aula expositiva em demasia; } \\
\text { Achar que o aluno sabe tudo. }\end{array}$ \\
\hline
\end{tabular}

\begin{tabular}{|c|c|c|c|}
\hline & \multicolumn{3}{|c|}{$\begin{array}{c}\text { Percepções dos Coordenadores Pedagógicos (CP) acerca da prática docente dos professores } \\
\text { de Geografia da Rede Escolar SESI-SP }\end{array}$} \\
\hline & \multicolumn{3}{|c|}{ (Grupo 07) } \\
\hline CP & $\begin{array}{l}01 \text { - } 0 \text { que caracteriza um bom } \\
\text { professor de Geografia }\end{array}$ & $\begin{array}{l}02 \text { - Que ações [do professor de } \\
\text { Geografia] mais contribuem para a } \\
\text { aprendizagem dos alunos? }\end{array}$ & $\begin{array}{l}03 \text { - Quais os equívocos mais } \\
\text { comuns na prática dos } \\
\text { professores [de Geografia]? }\end{array}$ \\
\hline 001 & $\begin{array}{l}\text { Comprometimento com ações e } \\
\text { expectativas do plano de trabalho } \\
\text { docente; } \\
\text { Desenvolver atividades que estão } \\
\text { dentro da concepção do SESI. }\end{array}$ & $\begin{array}{l}\text { Planejamento de } \quad \text { aulas; } \\
\text { Desenvolvimento das atividades } \\
\text { diferenciadas e diversificadas. }\end{array}$ & $\begin{array}{l}\text { Trabalhar apenas um } \\
\text { instrumento de trabalho. }\end{array}$ \\
\hline 002 & $\begin{array}{l}\text { Que domina os conteúdos e prática } \\
\text { os procedimentos metodológicos. }\end{array}$ & $\begin{array}{l}\text { A mobilização para aprendizagem. } \\
\text { Investir em boas estratégias para } \\
\text { esse fim é o caminho para sensibilizá- } \\
\text { lo e significar os conteúdos. }\end{array}$ & $\begin{array}{l}\text { Não considerar os } \\
\text { conhecimentos da classe } \\
\text { para planejar suas ações. }\end{array}$ \\
\hline 003 & $\begin{array}{l}\text { Atualizado; Motivado (...) } \\
\text { Comprometido; }\end{array}$ & $\begin{array}{l}\text { A abordagem diferenciada; O } \\
\text { domínio do assunto (professor); } \\
\text { O elo entre conteúdo e a } \\
\text { demonstração (teoria e prática). }\end{array}$ & $\begin{array}{l}\text { O tradicionalismo; falta de } \\
\text { mobilização. }\end{array}$ \\
\hline 004 & Atualizado; Motivador. & $\begin{array}{l}\text { Contextualização; Uso de estratégias } \\
\text { motivadoras. }\end{array}$ & $\begin{array}{ll}\text { Trazer sempre textos } \\
\text { prontos. }\end{array}$ \\
\hline 005 & $\begin{array}{l}\text { Atualizado; Saber bem seus } \\
\text { conteúdos; Motivar os alunos. }\end{array}$ & $\begin{array}{l}\text { Promover atividades que os alunos } \\
\text { sejam ativos; Construir os conceitos } \\
\text { junto com os alunos. }\end{array}$ & $\begin{array}{l}\text { Trazer sempre coisas } \\
\text { prontas; } \\
\text { Achar que os alunos não vão } \\
\text { conseguir; Mediar } \\
\text { construção } \\
\text { conhecimento. }\end{array}$ \\
\hline 006 & $\begin{array}{l}\text { Saber bem o conteúdo que vai } \\
\text { trabalhar; Estar por dentro da } \\
\text { atualidade; Ser comprometido com } \\
\text { seu trabalho. }\end{array}$ & $\begin{array}{l}\text { Trazer informações novas e atuais; } \\
\text { Incentivá-los à pesquisas e leituras. }\end{array}$ & $\begin{array}{l}\text { Quando ele deixa o aluno } \\
\text { sem nota por que não } \\
\text { entregou o trabalho; } \\
\text { Trabalha apenas com } \\
\text { perguntas e resposta. }\end{array}$ \\
\hline 007 & $\begin{array}{l}\text { Atualizado; } \\
\text { Saber bem o conteúdo }\end{array}$ & $\begin{array}{l}\text { Despertar a curiosidade e a vontade } \\
\text { de aprender. }\end{array}$ & $\begin{array}{l}\text { Utilizar aulas expositivas o } \\
\text { tempo todo. }\end{array}$ \\
\hline
\end{tabular}




\begin{tabular}{|c|c|c|c|}
\hline 008 & $\begin{array}{l}\text { Domínio de conteúdo; Saber } \\
\text { contextualizar e relacionar os } \\
\text { conteúdos aos fatos atuais; } \\
\text { Postura, boa relação com os alunos. }\end{array}$ & $\begin{array}{l}\text { Desenvolver atividades que } \\
\text { possibilitem aos alunos realizar uma } \\
\text { leitura de mundo nas mais variadas } \\
\text { perspectivas. }\end{array}$ & $\begin{array}{l}\text { Não perceber que a } \\
\text { intervenção deve ser } \\
\text { constante, bem como o } \\
\text { incentivo e mobilização dos } \\
\text { alunos são muito importante } \\
\text { para uma aprendizagem } \\
\text { significativa. }\end{array}$ \\
\hline 009 & $\begin{array}{l}\text { Que ele goste do que faz e faça com } \\
\text { "gosto"; Que não melindrado. }\end{array}$ & 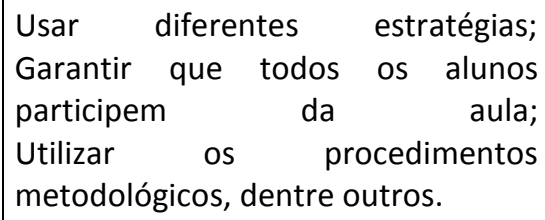 & $\begin{array}{l}\text { Não contextualizar o } \\
\text { conteúdo trabalhado ficando } \\
\text { estanque o aprendizado. }\end{array}$ \\
\hline 010 & $\begin{array}{l}\text { Trabalha dentro de um contexto; } \\
\text { Mobiliza os alunos para o } \\
\text { conhecimento; Trabalha com } \\
\text { temas atuais; media o processo; } \\
\text { Diversifica estratégias }\end{array}$ & 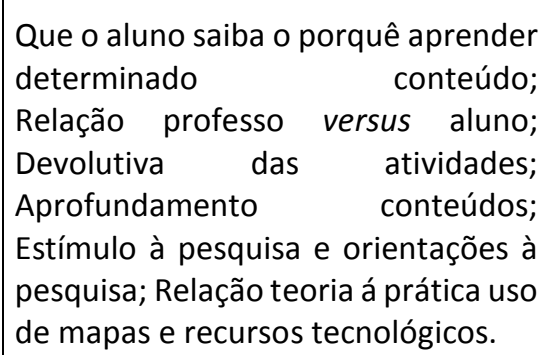 & $\begin{array}{l}\text { Achar que a avaliação está a } \\
\text { parte do processo. }\end{array}$ \\
\hline 011 & $\begin{array}{l}\text { Que se mantém informado, } \\
\text { atualizado; Dinâmico e ousado; } \\
\text { Questionador e que relacione sua } \\
\text { área com as demais. }\end{array}$ & $\begin{array}{l}\text { Pesquisa bem orientada; Situações } \\
\text { que favoreçam reflexão, análise de } \\
\text { dados e como impacta no seu mundo } \\
\text { "próximo da sua realidade e no } \\
\text { mundo de maneira geral. }\end{array}$ & $\begin{array}{l}\text { Uso excessivo de vídeos sem } \\
\text { contextualização e sem } \\
\text { conclusão dos assuntos em } \\
\text { foco (fechamento) }\end{array}$ \\
\hline 012 & $\begin{array}{l}\text { Problematiza; Sabe avaliar; Faz } \\
\text { bom plano Docente; Conhece o } \\
\text { conteúdo; Cuida da disciplina. }\end{array}$ & $\begin{array}{lrr}\text { Contrato } & \text { Didático/ } & \text { Pedagógico; } \\
\text { Roteiros; } & \text { leituras } & \text { diversas; } \\
\text { Participação na aula motivação } & \text { na } \\
\text { (procedimentos metodológicos). }\end{array}$ & $\begin{array}{l}\text { Auto - estima; Entrar em } \\
\text { conflito com o aluno não } \\
\text { sabe resolver conflito; Se } \\
\text { apega a nota ao invés da boa } \\
\text { aula. }\end{array}$ \\
\hline 013 & $\begin{array}{l}\text { Saiba motivar os alunos na busca do } \\
\text { conhecimento }\end{array}$ & $\begin{array}{l}\text { As diferentes estratégias utilizadas } \\
\text { pelo professor e a convicção daquilo } \\
\text { que está ensinando }\end{array}$ & $\begin{array}{l}\text { Achar que já sabem tudo e } \\
\text { não aceitam o novo. }\end{array}$ \\
\hline 014 & $\begin{array}{l}\text { Atualizado; } \\
\text { literários; diferentes gêneros } \\
\text { Trabalhar com contextualizar; } \\
\text { diversificadas; Propicia as } \\
\text { linguagens orais e escrita }\end{array}$ & $\begin{array}{l}\text { Leitura de diferentes gêneros; } \\
\text { Utiliza de diferentes estratégias; } \\
\text { Contextualize os conhecimentos com } \\
\text { o cotidiano dos alunos; } \\
\text { Propicie pesquisas, debates. }\end{array}$ & $\begin{array}{l}\text { Encorajar a decoreba; Não } \\
\text { proporcionar o contato com } \\
\text { diferentes textos e opiniões. }\end{array}$ \\
\hline 015 & $\begin{array}{l}\text { Que contextualize o conteúdo de } \\
\text { forma que o aluno realmente } \\
\text { aprenda. }\end{array}$ & $\begin{array}{l}\text { Atividades extra-classe; Atividades } \\
\text { práticas; Atividades desafiadoras que } \\
\text { despertem o interesse dos alunos. }\end{array}$ & $\begin{array}{l}\text { Não comprometimento; } \\
\text { Falta de domínio do } \\
\text { conteúdo; Falta de liderança. }\end{array}$ \\
\hline
\end{tabular}




\begin{tabular}{|c|c|c|c|}
\hline 016 & $\begin{array}{l}\text { Domínio de conteúdo; Didática-> } \\
\text { Despertar o interesse dos alunos } \\
\text { para a aprendizagem; mediar a } \\
\text { construção de conhecimentos } \\
\text { pelos alunos; Saber intervir para } \\
\text { que os alunos se desenvolvam ; } \\
\text { Promover o ensino e aprendizagem } \\
\text { e pesquisa numa abordagem sócio - } \\
\text { interacionista }\end{array}$ & $\begin{array}{l}\text { Estratégias diversificadas; Saber } \\
\text { ouvir os alunos; Aulas participativas e } \\
\text { encantadoras; Conhecer as } \\
\text { características das faixas etárias. }\end{array}$ & Ensino por memorização. \\
\hline 017 & Dinâmico; Pesquisador; orientador. & $\begin{array}{l}\text { Interesse; Dinâmica da aula; Um bom } \\
\text { professor. }\end{array}$ & $\begin{array}{l}\text { Dificuldades em controlar a } \\
\text { sala de aula; Domínio do } \\
\text { conteúdo; } \\
\text { Insegurança. }\end{array}$ \\
\hline 018 & $\begin{array}{l}\text { Professor que busca a realidade do } \\
\text { aluno; Boa relação interpessoal; } \\
\text { Busca de ajuda; Sabe ouvir. }\end{array}$ & $\begin{array}{l}\text { Professor que problematiza; } \\
\text { levanta conhecimentos prévios; } \\
\text { Procedimentos metodológicos; } \\
\text { Otimização do tempo. }\end{array}$ & $\begin{array}{l}\text { Falta de domínio da sala } \\
\text { (disciplina); } \\
\text { Sabe o conteúdo, mas não } \\
\text { transmite. }\end{array}$ \\
\hline 019 & $\begin{array}{l}\text { Domina o conteúdo; Compreender } \\
\text { as expectativas; Atualização; Aulas } \\
\text { Dinâmicas. }\end{array}$ & $\begin{array}{l}\text { Relacionamento interpessoal; } \\
\text { Comprometimento; } \\
\text { Acompanhamento individualizado. }\end{array}$ & $\begin{array}{l}\text { Achar que tudo sabe; } \\
\text { Deixar de intervir e de } \\
\text { oferecer devolutivas aos } \\
\text { educandos. }\end{array}$ \\
\hline 020 & $\begin{array}{l}\text { Ter um conhecimento específico e } \\
\text { amplo da disciplina; Saber usar os } \\
\text { procedimentos - } \quad \text { mobilizar, } \\
\text { sistematizar e avaliar. }\end{array}$ & $\begin{array}{l}\text { Aprendizagens que garantam os } \\
\text { procedimentos metodológicos. }\end{array}$ & $\begin{array}{l}\text { Auto - estima ( dificuldade } \\
\text { em ser a autoridade na } \\
\text { relação entre professor e } \\
\text { aluno). }\end{array}$ \\
\hline 021 & $\begin{array}{l}\text { Pesquisador/ leitor/ Clareza na } \\
\text { comunicação. }\end{array}$ & $\begin{array}{l}\text { Aplicação de diversos recursos, } \\
\text { estratégias e intervenções pontuais } \\
\text { para que estimule o alunos. }\end{array}$ & $\begin{array}{l}\text { Pouco aproveitamento dos } \\
\text { conhecimentos prévios dos } \\
\text { alunos, para tomada de } \\
\text { decisões mais assertivas }\end{array}$ \\
\hline 022 & $\begin{array}{l}\text { Que seja mais estudioso, que se } \\
\text { mantenha atualizado e bem } \\
\text { informado, portanto, conheça bem } \\
\text { sua disciplina e com o que se } \\
\text { relaciona. }\end{array}$ & $\begin{array}{l}\text { Pesquisa orientada; } \begin{array}{l}\text { Debates; } \\
\text { Situações que favoreçam análise, } \\
\text { crítica e argumentação. }\end{array}\end{array}$ & $\begin{array}{l}\text { Pesquisa pela pesquisa; Falta } \\
\text { de contextualização; Falta de } \\
\text { sistematização (fechamento } \\
\text { dos assuntos);Instrumentos } \\
\text { avaliativos diversificados. }\end{array}$ \\
\hline 023 & $\begin{array}{l}\text { Pesquisador de sua área; Querer } \\
\text { aprender e se adequar novos } \\
\text { conhecimentos; Dinâmico, }\end{array}$ & $\begin{array}{l}\text { Aluno participativo; Estratégias } \\
\text { diferentes; Estimular a pesquisa; } \\
\text { Parceira, }\end{array}$ & Adaptação a mudanças. \\
\hline 024 & $\begin{array}{l}\text { Partem de uma situação problema } \\
\text { para ensinar; Conhecimento sobre } \\
\text { o que precisam ensinar; dinâmico; } \\
\text { Atualizado. }\end{array}$ & $\begin{array}{l}\text { Utilizar recursos pedagógicos; } \\
\text { Contextualizar as informações para } \\
\text { construir o conhecimento; Desafiar; } \\
\text { Pesquisa (ora com orientação, ora } \\
\text { com promoção). }\end{array}$ & $\begin{array}{l}\text { Propor a memorização como } \\
\text { produto final; Desatualizado; }\end{array}$ \\
\hline 025 & $\begin{array}{l}\text { Domínio de conteúdo; Relação de } \\
\text { empatia com aluno; Conhecer / } \\
\text { compreender Rede SESI de Ensino ( } \\
\text { sobre Educação); Gostar de estudar } \\
\text { e atualizar -se; } \\
\text { Ter boas relações interpessoais. }\end{array}$ & $\begin{array}{l}\text { Estimular / incentivar / possibilitar a } \\
\text { participação dos alunos; Auxiliar os } \\
\text { alunos na construção do } \\
\text { conhecimento; Planejar muito bem a } \\
\text { aula; Propor desafios. }\end{array}$ & $\begin{array}{lr}\text { Sala silenciosa } & \text { e mais } \\
\text { produtiva; } & \text { Valorizar } \\
\text { memorização; } & \text { Improvisar } \\
\text { aulas; } & \\
\text { Não enxergar os alunos como } & \\
\text { indivíduos. }\end{array}$ \\
\hline
\end{tabular}




\begin{tabular}{|c|c|c|c|}
\hline 026 & $\begin{array}{l}\text { Domínio de } \quad \begin{array}{r}\text { conteúdo; } \\
\text { Comprometido em } \\
\text { atualizar-se. }\end{array} \\
\text { sempre }\end{array}$ & $\begin{array}{l}\text { Utilizar -se dos procedimentos } \\
\text { metodológicos com propriedade. }\end{array}$ & $\begin{array}{l}\text { Trabalho } \\
\text { tradicional }\end{array}$ \\
\hline 027 & $\begin{array}{l}\text { Atualizado - curioso; Boa relação } \\
\text { professor / aluno; Aulas planejadas. } \\
\text { Boas avaliações. }\end{array}$ & $\begin{array}{l}\text { Boas situações problemas; Aulas } \\
\text { planejadas; } \\
\text { contextualizados. }\end{array}$ & $\begin{array}{l}\text { Achas que já dominam o } \\
\text { conteúdo e não ser } \\
\text { investigador. }\end{array}$ \\
\hline 028 & $\begin{array}{l}\text { Pesquisador e estudioso dos } \\
\text { fenômenos, físico - espacial e } \\
\text { social: Ter boas estratégias } \\
\text { didáticas; Orientador e mediador } \\
\text { de aprendizagem. }\end{array}$ & $\begin{array}{l}\text { Levar o aluno perceber as mudanças } \\
\text { que compõe o ambiente em que vive } \\
\text { (sociais, ambientais, mudanças } \\
\text { políticas); } \\
\text { Pesquisa bem orientada ( critérios } \\
\text { estabelecidos); }\end{array}$ & $\begin{array}{l}\text { O aluno fazer pesquisa } \\
\text { coletando dados somente o } \\
\text { material sem fundamentação } \\
\text { necessáriar para } \\
\text { aprendizagem; } \\
\text { Abordagem por vídeos que } \\
\text { não contextualizam com o } \\
\text { cotidiano; }\end{array}$ \\
\hline 029 & $\begin{array}{l}\text { Que domine o conteúdo; Que } \\
\text { tenha boa didática e que consiga } \\
\text { desenvolver na prática os } \\
\text { procedimentos metodológicos com } \\
\text { o objetivo do ensino - } \\
\text { aprendizagem. }\end{array}$ & 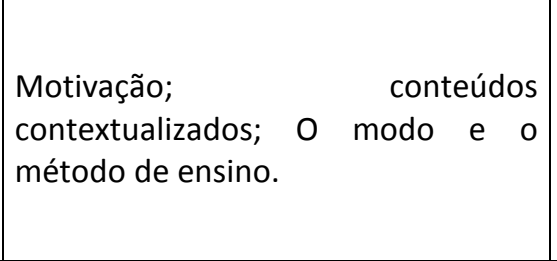 & $\begin{array}{l}\text { Não registrar de fato o que o } \\
\text { professor realiza em solo de } \\
\text { aula; Não participar o aluno } \\
\text { dentro do contexto da aula. }\end{array}$ \\
\hline 030 & $\begin{array}{l}\text { Aquele que sabe desafiar e interagir } \\
\text { com o grupo. }\end{array}$ & $\begin{array}{l}\text { Diálogo; Saber ouvir; Indagar; } \\
\text { Interpretar. }\end{array}$ & $\begin{array}{l}\text { Acredito ser apresentar } \\
\text { mapas fora de um contexto. }\end{array}$ \\
\hline 031 & $\begin{array}{l}\text { Aquele que sabe desafiar e interagir } \\
\text { com o grupo. }\end{array}$ & $\begin{array}{l}\text { Motivação; Dinâmica;Protagonismo } \\
\text { dos alunos na aprendizagem. }\end{array}$ & $\begin{array}{l}\text { Aulas estritamente } \\
\text { expositivas; } \\
\text { Falta de domínio do } \\
\text { conteúdo; } \\
\begin{array}{l}\text { Problemas na relação } \\
\text { professor / aluno. }\end{array}\end{array}$ \\
\hline 032 & $\begin{array}{l}\text { Propõe pesquisas e estudos do } \\
\text { meio; Plugado/ informado na } \\
\text { realidade; Diversifica estratégias de } \\
\text { ensino (mapas, vídeos, } \\
\text { maquete,mídias, etc.). }\end{array}$ & $\begin{array}{l}\text { Participar; Ser protagonista de sua } \\
\text { aprendizagem; pesquisa; analisar, } \\
\text { comparar, criticar e interpretar. }\end{array}$ & $\begin{array}{l}\text { Ensinar ler o mapa, sem } \\
\text { ensinar interpretar os dados } \\
\text { contextualizando com a } \\
\text { realidade. }\end{array}$ \\
\hline 033 & $\begin{array}{lr}\text { Pesquisador; } & \text { Articulador; } \\
\text { Contextualizado } & \text { Dinâmico; } \\
\text { Reflexivo; Instigador; Investigador: } & \\
\text { Flexível. } & \end{array}$ & $\begin{array}{l}\text { Atividades Significativas; Situações } \\
\text { problemas; Desafios; Estimulo a } \\
\text { pesquisa; Estratégias Diferenciadas. }\end{array}$ & $\begin{array}{l}\text { Focas apenas o conteúdo; } \\
\text { Avaliar só resultado final } \\
\text { apresentar sempre uma } \\
\text { estratégia formatada; Aulas } \\
\text { passivas, apenas expositivas. }\end{array}$ \\
\hline
\end{tabular}

